\author{
Universidade de São Paulo \\ Instituto de Física \\ Instituto de Química \\ Instituto de Biociências \\ Faculdade de Educação
}

\title{
A sala de aula, o estar junto e a \\ transformação sob a perspectiva da \\ Biologia do Conhecer
}

Jacqueline Camargo Nogueira Contreiras

São Paulo

2011 


\author{
Universidade de São Paulo \\ Instituto de Física \\ Instituto de Química \\ Instituto de Biociências \\ Faculdade de Educação
}

\title{
A sala de aula, o estar junto e a transformação sob a perspectiva da Biologia do Conhecer
}

\author{
Jacqueline Camargo Nogueira Contreiras
}

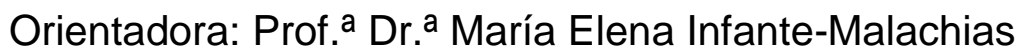

Dissertação de mestrado apresentada ao Instituto de Física, Instituto de Química, Instituto de Biociências e à Faculdade de Educação da Universidade de São Paulo, para obtenção do título de mestre em Ensino de Ciências. 
AUTORIZO A REPRODUÇÃO PARCIAL DESTE TRABALHO, PARA FINS DE ESTUDO E PESQUISA, DESDE QUE CITADA A FONTE. A REPRODUÇÃO COMERCIAL, EM TODO OU EM PARTE POR QUALQUER MEIO, SOMENTE É PERMITIDA COM A EXPRESSA AUTORIZAÇÃO ESCRITA DO AUTOR.

\section{FICHA CATALOGRÁFICA \\ Preparada pelo Serviço de Biblioteca e Informação do Instituto de Física da Universidade de São Paulo}

Contreiras, Jacqueline Camargo Nogueira

A sala de aula, o estar junto e a transformação sob a perspectiva da Biologia do Conhecer. - São Paulo, 2011.

Dissertação (Mestrado) - Universidade de São Paulo.

Faculdade de Educação, Instituto de Física, Instituto de

Química e Instituto de Biociências

Orientador: Profa. Dra. María Elena Infante-Malachias

Área de Concentração: Ensino de Biologia

Unitermos: 1. Bilogia; 2. Interação Professor Aluno; 3. Ensino e Aprendizagem. 
Aos meus pais, Edson e Nilze, que me permitiram construir asas... 


\section{AGRADECIMENTOS}

À Profa. Dra. María Elena Infante-Malachias, orientadora no mais carinhoso dos significados, exemplo de ser humano e de profissional, que se tornou uma amiga durante esse meu caminhar.

Ao José Eduardo que se mostrou um companheiro atencioso e compreensivo.

Aos Profs. Drs. Esteban Tuesta e Ana Amélia Benedito da Silva, da EACH, pelas ricas contribuições ao meu trabalho.

À Profa. Dra. Nilda Montes Villanueva, da Universidade Federal de Lima, por sua contribuição nas análises estatísticas.

Aos professores que contribuíram para a minha pesquisa, respondendo ao opiniário e dando vida ao meu trabalho com seus comentários e sugestões.

Aos professores do grupo de pesquisa pelas discussões e contribuições, em especial ao Herbert por nossas conversas "maturanescas".

Às amigas, Malu, Ana, Aloe e Camila que torceram, incentivaram e acreditaram em mim.

Aos amigos e familiares que de alguma forma me apoiaram, e, em especial, ao meu sobrinho Thomas, por sua boa vontade em colaborar. 


\section{RESUMO}

CONTREIRAS, Jacqueline Camargo Nogueira. A sala de aula, o estar junto e a transformação sob a perspectiva da Biologia do Conhecer. 2011. 138p. Dissertação (Mestrado em Ensino de Ciências-Ensino de Biologia) - Instituto de Biociências, Faculdade de Educação, Universidade de São Paulo, São Paulo, 2011.

Nesta pesquisa estudamos a Biologia do Conhecer do epistemólogo chileno Humberto Maturana e discutimos as implicações educacionais da mesma. Foram investigadas as concepções sobre a relação pedagógica de 46 professores de ciências em exercício que aceitaram participar deste estudo exploratório com o objetivo de identificar o quanto essas concepções docentes se aproximavam ou se distanciavam das ideias propostas por Maturana. Para obter as concepções dos professores foi elaborado um com uma escala do tipo Likert com notas de 1 a 9 . Além disso, se pediu ao professor que respondesse por extenso a quatro questões dissertativas. A análise quantitativa dos dados obtidos pela escala Likert, foi feita utilizando o teste de análise de variância (ANOVA) e o teste Tukey para comparação de médias. Os textos produzidos pelos professores foram analisados qualitativamente pelo método dedutivo utilizando três categorias teóricas. Os resultados mostram que as concepções expressas pelos professores se distanciam das ideias de Maturana. A emoção em sala de aula é considerada de extrema importância, mas a razão é ainda mais valorizada, o conhecimento é considerado o fundamento do humano. Em geral não se valoriza o diálogo, e aparentemente o professor desempenha seu trabalho utilizando uma máscara social. Finalmente se discute que a relação de ensino/aprendizagem deveria promover relações humanas na sala de aula, e se as ideias de Maturana fossem discutidas durante o processo de formação inicial e continuada de professores, poderiam estimular a reflexão do professor e gerar a possibilidade de transformações na relação pedagógica destes profissionais.

Palavras-chave: Biologia do Conhecer, Humberto Maturana, Relação pedagógica. 


\begin{abstract}
CONTREIRAS, Jacqueline Camargo Nogueira. The classroom, be together and the transformation from the perspective of Biology of Cognition. 2011. 138p. Dissertation (Master in Science Education - Biology Education) - Institute of Biosciences, School of Education, University of São Paulo, São Paulo, 2011.
\end{abstract}

\title{
Abstract
}

In this research we study the biology of Cognition of the Chilean epistemologist Humberto Maturana, and discuss his educational implications to the pedagogical relationship teacher-student-knowledge. We investigate also the conceptions of the pedagogical relationship of 46 active science teachers who agreed to participate in this exploratory study. The goal was to identify how close conceptions of science teachers are from the ideas proposed by Maturana.

To get teachers ideas was prepared test asking if they agree or not with 15 ideas adapted from the works of the author, through a Likert-type scale with notes from 1 to 9. In addition, teachers were asked to respond in writing to four questions in order to share their criticisms, suggestions and thoughts about the test and also about the ideas of Maturana. The quantitative analysis of data obtained by scale Likert was made using the test analysis of variance (ANOVA) and Tukey test for comparison of averages. The texts produced by the teachers were analyzed qualitatively by deductive method using three theoretical categories. The results show ideas expressed by teachers do not match those from Maturana. The emotion in the classroom is considered of extreme importance, but the reason is even more valued, as knowledge is considered the foundation of human. In general the dialogue is not valued, and the teacher plays his role using a social mask. Finally it discusses that the relationship of teaching/learning should promote human relationships in the classroom. And that Maturana's ideas, discussed during the process of initial and continuous training of teachers, could stimulate the reflection of the teacher and generate the possibility of changes in pedagogical relationship of these professionals.

Keywords: Biology of Cognition, Humberto Maturana, Pedagogical relationship 


\section{Sumário}

1. Introdução

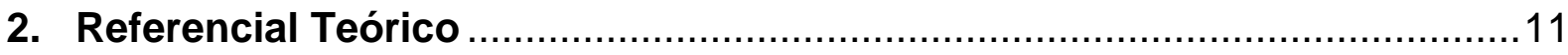

2.1 Concepções epistemológicas de professores de ciências .............................11

2.2. As Concepções Epistemológicas de Humberto Maturana.............................17

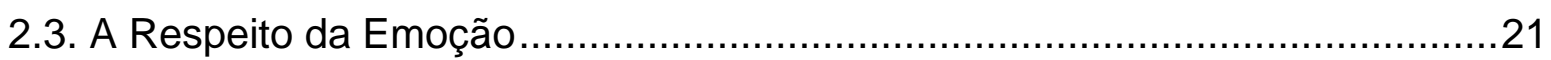

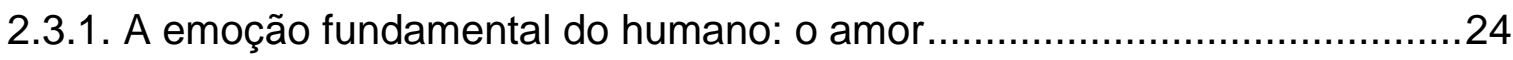

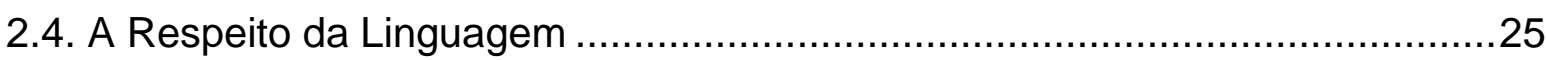

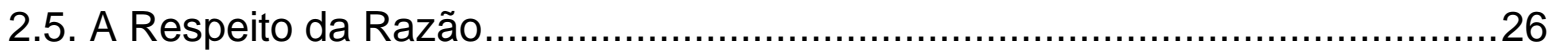

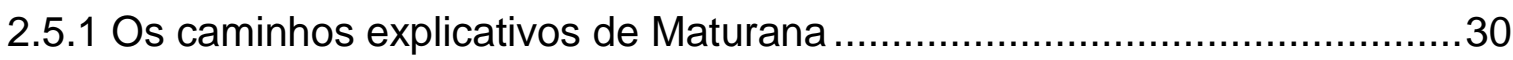

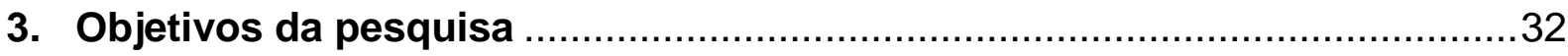

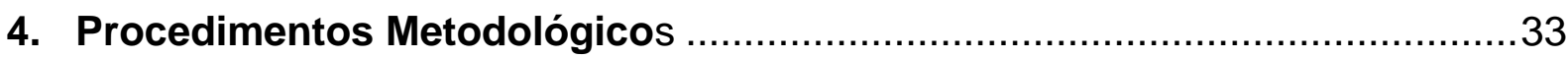

4.1. Análise e discussão preliminar do questionário de notas ............................34

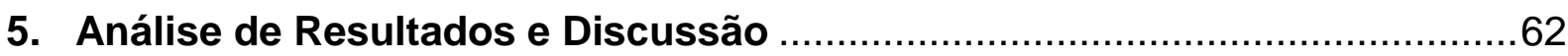

5.1. Análise das respostas para a escala Likert do opiniário ..................................62

5.2. Análise das perguntas abertas do opiniário...............................................

5.3. A importância do Ensino/Aprendizagem Coinspirados ....................................88

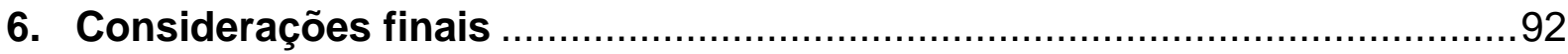

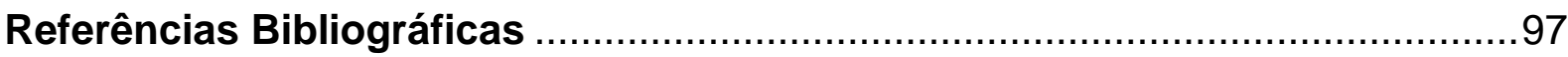

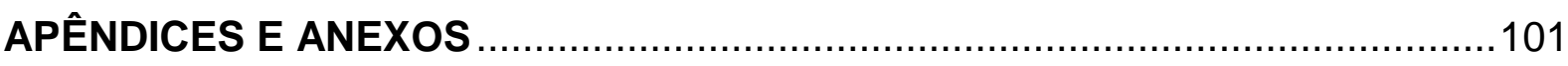

APÊNDICE 1 - Tabela4-Questionário do tipo Likert aplicado como pré-teste .....101

APÊNDICE 2. Tabela 5-Questionário de notas aplicado aos professores de ciências

APÊNDICE 3- Tabela6- Questões aplicadas aos professores e as categorias

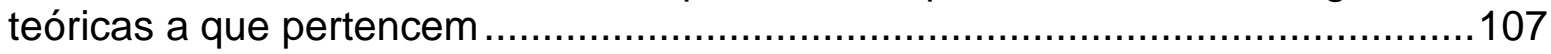

APÊNDICE 4- Tabela7. Tabulação das notas dadas pelos professores às perguntas do questionário.

APÊNDICE 5 - Tabela 8. Opiniário aplicado aos professores de Ciências

APÊNDICE 6- Tabela 9 Respostas dos professores às afirmações do opiniário.

APÊNDICE 7- Tabela de identificação dos professores.......................................117

APÊNDICE 8 - Transcrição das respostas da questão № 3 …..............................119

APÊNDICE 9 - Transcrição das respostas da questão ํo4 ….............................123

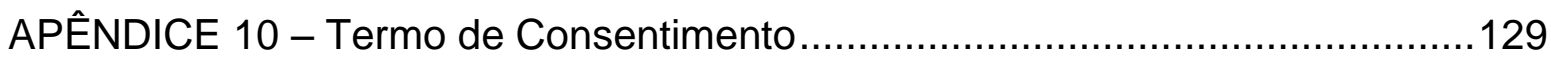

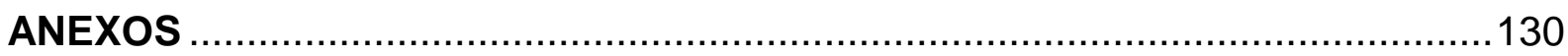

ANEXO 1- Resultados da análise de variância (ANOVA) .................................130 


\section{Introdução}

Afinal, minha presença no mundo não é a de quem a ele se adapta, mas a de quem nele se insere. É a posição de quem luta para não ser apenas objeto, mas sujeito também da História.

Paulo Freire

As inquietações que me levaram a procurar o mestrado surgiram da minha experiência de alguns anos como professora, por esta razão, optei por utilizar intencionalmente a primeira pessoa nesta introdução, como também nas discussões e considerações finais desta dissertação.

Com vinte anos de experiência em sala de aula senti a necessidade de entender o caminho percorrido por mim no magistério. O contato com vários e diferentes colegas, suas certezas e incertezas a respeito de aprendizagem, conhecimento, relações entre professores e alunos, razão e emoção enriqueceram minha vida e aumentaram minhas inquietações.

Estou no meu momento de "viver no rastro do navio" (Bauman, 1999).

[...] o navio passou, encrespando as águas, produzindo turbulência, de modo que todos os navegantes ao redor têm que refazer o seu curso dos seus barcos, enquanto os que caíram n'água têm que nadar com força para alcançá-los. Assim que as águas de novo se aquietarem, porém, nós, os navegantes e ex-passageiros, podemos examinar melhor 0 navio que causou tudo isso [...] estamos atrás dele e não mais de pé no seu convés. Assim podemos vê-lo em toda a sua forma impressionante, de proa a popa, examiná-lo, apreciá-lo, traçar a rota que faz. Podemos agora decidir se seguimos ou não seu curso. Podemos também protestar contra as ordens do capitão [...] (p.110).

A ideia de rever o meu percurso profissional muito se aproxima de minhas inquietações sobre a educação. O navio passa, ficamos atrás dele e podemos olhálo inteiramente, analisando, apreciando, decidindo se vamos acompanhá-lo ou não, se concordamos com sua rota, com seu curso. Como Maroni (2008) mesmo declara:

[...] viver no rastro significa usufruir de um novo ponto de observação, uma nova perspectiva, a partir da qual podemos olhar e avaliar nosso passado recente: a modernidade [...] (Maroni 2008, p.22).

Parece ser uma explicação de consenso entre professores de ciências que o grande problema da aprendizagem está no próprio aluno. Frases como: "os alunos 
não tem pré-requisitos"; "as gerações estão cada vez mais desinteressadas"; "nada os interessa", e a certeza de que muitos dos problemas do ensino são consequências do sistema de aprovação automática, parecem permear as conversas de professores em suas reuniões, durante seus intervalos de aula e até mesmo em bate papos do dia a dia. Em contrapartida vi professores que ditavam textos para seus alunos, que passavam exercícios na lousa para serem memorizados, dos quais alguns seriam cobrados nas avaliações. Professores que tinham uma postura bastante autoritária em sala de aula e que se orgulhavam de ter tantas notas vermelhas em seus diários. Tudo isso muitas vezes me desanimava e não conseguia visualizar alternativas para este problema.

Foi em busca destas alternativas de mudanças que ingressei no mestrado, na área de Ensino de Ciências, para tentar entender como se dá essa relação professor, aluno e conhecimento e como nós professores podemos desencadear mudanças em nossos alunos e em nossas próprias práticas.

Não considero correto e nem justo depositar todo o ranço e mazelas da educação sobre os ombros dos alunos. As dificuldades existem e devem ser analisadas de uma maneira global, sem acusações e sim em um movimento reflexivo conjunto de todos os atores sociais envolvidos no processo educacional.

Alguns autores como Porlán, (1998); Prawat, (1992) e outros, distinguem algumas crenças do professor a respeito da aprendizagem dos alunos, tais como, que os alunos aprendem se prestam atenção ao professor, e se não aprendem é porque estudam pouco ou possuem problemas familiares. Esses professores também consideram como sendo o seu papel o de transformar as ideias dos alunos em verdades científicas.

Podemos verificar uma visão simplista, e por que não dizer reducionista, sobre a aprendizagem de Ciências e mais uma vez deixamos de ver o todo para olharmos uma fina fatia desta tríade tão conhecida, a relação entre professores, alunos e o conhecimento. As afirmações vindas de professores da área me fizeram pensar o quanto nós professores precisamos "desalojar" de nosso pessimismo e nossa passividade. Maroni (2008) usa o termo desalojamento para expressar o processo de refazer seu caminho, de deixar de ser uma especialista e "parar para pensar". Usarei o termo desalojar no sentido de mudar, sair do lugar comum, da 
estagnação que percebo em muitos professores, para os quais parece que nada pode ser feito.

Vivemos hoje em meio a uma verdadeira avalanche de informações diárias, vindas de todos os cantos do planeta, entrando em nossas casas, escritórios, escolas, em nossa vida e os nossos alunos podem obter informações digeridas e prontas rapidamente. São tantas as novidades, os avanços tecnológicos e o volume de informações disponíveis, que é uma tarefa inviável a qualquer indivíduo dar conta de tudo isso. Diante dessa situação, continuamos considerando a escola como a vinculação que os jovens têm com a cultura e o saber, no entanto, a dimensão pessoal que se configura na relação pedagógica, parece-nos cada vez mais relevante de se estudar.

A escola deveria ser um espaço aberto às vivências e experiências, favorecendo as relações sociais e, portanto deve ser utilizada em toda sua capacidade de mudanças.

A escola é local de transformações, sejam elas para os alunos ou professores, é um espaço onde, segundo Pizzato (2010), citando Burbules e Torres (2003), ocorre a construção colaborativa do conhecimento e a busca da consciência crítica derivada da dialogicidade e da interatividade.

Com esta imagem de escola, isto é, como local de transformação, é que estudaremos a Biologia do Conhecer de Humberto Maturana e procuraremos identificar convergências e divergências em relação às ideias do autor nas concepções de professores de Ciências. 


\section{Referencial Teórico}

\subsection{Concepções epistemológicas de professores de ciências}

Alguns autores como Adúriz-Bravo (2001) concluíram que professores são seres humanos com crenças e valores definidos, emitem juízos e geram rotinas no seu desenvolvimento profissional. Portanto, é necessário que se leve em conta as concepções epistemológicas destes professores e seus conhecimentos sobre ciência para que se transforme o currículo e a formação de professores de ciências.

Sabemos (Adúriz-Bravo, 2001; Aznar et al, 2001) que a prática do professor está intimamente ligada à sua visão de ciência e de sua concepção epistemológica, por esta razão faz-se necessário um breve levantamento de autores que já investigaram a ideia de ciência que o professor possui e sua concepção sobre conhecimento e aprendizagem.

Praia e Cachapuz (1994) afirmam que a imagem de ciência que os alunos possuem depende do que Ihes foi proporcionado por seus professores de Ciências. Estes autores observaram que havia uma perspectiva empirista entre professores, que era independente dos conteúdos que ensinavam e para que esses professores possam ter uma perspectiva mais atual sobre a natureza do conhecimento científico é necessário que sejam preparados para tal finalidade. Por fim salientam a necessidade de cursos de formação inicial ou continuada que tratem dos aspectos epistemológicos.

Porlán (1995), após um levantamento de trabalhos sobre as crenças dos professores a respeito do ensino de Ciências, a ciência e a natureza do conhecimento concluiu que a concepção de ensino está centrada à explicação do professor, tendo como preocupação dominante os conteúdos, os quais vão nortear a dinâmica em uma sala de aula, e também a necessidade em se manter o controle e a direção da mesma.

O autor indica que na escola ainda predomina o ensino tradicional, além disso, a imagem de ciência é positivista do saber científico, onde o conhecimento que se ensina é o conhecimento verdadeiro, o qual reflete a realidade sendo, 
portanto absoluto e objetivo. Tudo isso favorece o aparecimento de mitos que influenciam no desenvolvimento individual e social dentro de uma sala de aula.

Bittencourt (2001) faz um levantamento das pesquisas que se detiveram em compreender a concepção de conhecimento do professor e seu trabalho parte da hipótese de que cada prática pedagógica está relacionada a uma perspectiva de educação; uma concepção de conhecimento e supõe uma teoria de aprendizagem. A autora tenta expor essas relações e indicar maneiras de compreender a epistemologia do professor no ensino de Ciências.

Considerando o empirismo inserido no pensamento metafísico, a autora mostrou que a concepção de conhecimento está associada à realidade e composta de verdades isoladas e absolutas captadas do mundo externo. Entender o professor como um sujeito de concepções epistemológicas e predominantemente empirista é importante para que o próprio professor volte a discutir sobre sua concepção de conhecimento.

A autora ainda coloca outra questão, pois se a concepção de conhecimento do professor leva a uma concepção de aprendizagem desse mesmo professor, essa concepção norteia sua prática pedagógica. Entende-se então, que essa concepção de conhecimento vem da formação acadêmica do professor.

Podemos incluir nesta concepção de conhecimento dos professores de ciências, sua própria experiência como estudante e em alguma medida as concepções epistemológicas de seus professores. Portanto experiências, agradáveis ou não na convivência com seus mestres, farão parte intrinsecamente de sua prática.

Através de sua pesquisa, Bonito (2008) verificou que grande parte dos professores e alunos de $4^{\circ} \stackrel{\circ}{a}$ a do Ensino Superior de Biologia considera o ensino como transmissão de conhecimentos e que aprender consiste em adquirir e aplicar conhecimento, indicando a prevalência de uma concepção de aprendizagem bancária nestes estudantes (Freire, 1996). Uma das principais conclusões de Bonito (2008) foi a de que o ensino é visto como uma transmissão de significados mostrando uma apropriação formal de conhecimentos. Para estes professores há uma associação entre atividades do aluno e aprendizagem com significados, o que 
leva o professor a diversificar suas atividades por acreditar que estas levam ao aprendizado e também ao desenvolvimento de atitudes e de modos de pensar.

Acevedo (2002) argumenta que as últimas investigações realizadas mostraram que os professores em geral não possuem uma boa compreensão da natureza das ciências e que os futuros professores de Ciências também não as tem. O autor sugere que se preste mais atenção na natureza da ciência nos cursos de formação de professores de Ciências e diz que um dos objetivos da didática das ciências deveriam ser as mudanças nas crenças dos professores sobre a natureza da ciência, pois "não se pode ensinar o desconhecido" (op.cit., p.653).

Acevedo (2010) propõe que um amplo domínio do conteúdo mais o conhecimento das crenças e ideias dos estudantes e os pontos de vista contemporâneos sobre a natureza da ciência aumentam a chance de um ensino eficaz desde que se tenha conhecimento didático geral e específico. O autor conclui que seria importante conhecer como estão as crenças do professor sobre a natureza da ciência quando o mesmo ministra suas aulas com diferentes conteúdos científicos.

Para Rosa e Rosa (2010) há grande importância em se compreender a natureza da ciência na ação pedagógica, partindo-se da idéia de que ciência é um processo.

[...] Isso requer um olhar sobre o ensino dessa ciência de modo diferente daquele conhecimento fragmentado, recortado e descontextualizado apresentado nos programas de ensino e consolidados pelos livros didáticos, ou mesmo, das estratégias utilizadas no desenvolvimento das atividades pedagógicas [...] (Rosa e Rosa 2010, p.8)

Ferraz e Oliveira (2006) investigaram as concepções de professores de ciência e biologia sobre a natureza da ciência e suas orientações didáticas. Verificaram que os professores tendem a manter as concepções de ciências que vivenciaram na universidade, e que essas concepções e suas próprias crenças sobre a natureza da ciência influem no processo de ensino aprendizagem e em sua prática pedagógica. Segundo estes autores os professores apresentam uma visão tradicional de ensino empregando aulas expositivas como estratégia de aula principal e atividades práticas para comprovar as teorias dadas, e não como prática investigativa. Nota-se que ao apresentar uma concepção construtivista da ciência o professor revela uma didática tradicional. 
[...] Isso revela o quanto é difícil a mudança na prática pedagógica dos professores, já que, embora tendo uma concepção epistemológica considerada avançada, a prática é mais resistente à mudança[...] (Ferraz e Oliveira 2006, p.102)

A mudança na prática pedagógica enfrenta vários obstáculos, podemos citar como um desses obstáculos a resistência do professor em pensar na possibilidade que um dos problemas do ensino/aprendizagem pode estar em sua própria prática. Muitos professores acreditam que a falta de conhecimentos prévios dos alunos prejudica $o$ aprendizado e, portanto não veem motivo em repensar sua prática $e$ mudar suas atitudes em sala de aula, afinal o problema não é dele.

Um dos motivos que leva o professor a manter sua paralisia frente ao ensino é a desvalorização do docente, seja ela moral ou financeira. A falta de respeito ao profissional impede que o mesmo queira mudar, pois não há recompensa.

O professor muitas vezes se desanima com as propostas ou currículos impostos pela política educacional e se enfraquece diante de tal situação. Giroux (1997) defende que as reformas educacionais reduzem os professores a técnicos especializados prontos pra aplicar programas curriculares reduzindo sua autonomia diante do desenvolvimento e planejamento curricular. $O$ autor defende a necessidade dos professores se tornarem intelectuais transformadores, cuja reflexão e sua prática levem seus alunos a obterem uma visão mais crítica do mundo, fortalecendo-os contra as práticas injustas, assumindo riscos e lutando contra as opressões.

Porlán, Rivero e Del Pozo (1998) citam diversos autores que mostram, em seus trabalhos, que professores transmitem uma imagem deformada do conhecimento e do trabalho científico, apresentando uma imagem da ciência como algo acabado, certo e em constante avanço. Em suas últimas revisões os autores, acima citados, manifestaram a tendência entre a maioria dos professores na ativa e professores em formação de uma visão positivista da ciência.

$\mathrm{Na}$ investigação didática feita por eles, obtiveram alguns resultados de acordo com o tempo de experiência do professor e de sua especialização. Professores com mais experiência apresentaram uma concepção epistemológica mais formal onde o conhecimento é transmitido e aprendido pelos alunos, já os professores mais especializados apresentam o conhecimento escolar como reduzido à eficácia dos 
processos técnicos do professor ao programar as atividades práticas aos alunos e também a transmissão a eles do conhecimento correto. Por último houve uma pequena parcela de professores que apresentaram uma visão mais relativista e complexa do conhecimento escolar.

No estudo de Kouladis e Ogborn (1989) sobre a visão que professores de ciências têm sobre o conhecimento científico, levando em consideração uma perspectiva filosófica e epistemológica, foram detectados no discurso dos professores, três pontos de vista diferentes sobre ciência:

[...] a) Indutivistas na metodologia tendem a ser contextualistas racionalistas nos critérios de demarcação e nos padrões de mudança da ciência, mas são mais relativistas em relação ao status do conhecimento científico; b) Contextualista no que se refere à metodologia tendem a ser mais racionalistas em relação aos critérios de demarcação e ao status do conhecimento científico e essas duas categorias podem ser associadas à outra; e c) ecléticos são na maioria dos casos ecléticos nos quatro temas [...] (p.279)

Os autores consideram ecléticos os professores que não se manifestam em um padrão de respostas pré-determinadas.

Ravanal e Quintanilla (2010) concluem que está instalada em professores de biologia em exercício uma "imagem de ciência racional, dogmática, com orientações epistemológicas tradicionais e empiristas, que contrariam as atuais pretensões da natureza da ciência que o professorado de Biologia deve conceber para melhorar sua prática" (p.115). Em seu trabalho os autores verificaram que docentes possuem uma ideia de ciência como neutra e imparcial o que dificulta a participação em temas sócio científicos por pessoas que não sejam do meio acadêmico.

Aznar et al., 2001 mostra a necessidade em se refletir e modificar a formação inicial dos professores de ciência:

[...] Refletir sobre conteúdo escolar que o futuro professor terá que ensinar e sobre o que seus alunos sabem e podem aprender para poder realizar a transposição didática que permita elaborar conhecimento escolar a partir do conhecimento científico e cotidiano [...] Incrementar o tratamento das questões epistemológicas relacionadas com o conhecimento científico e também com o conhecimento cotidiano [...] Aprofundar as características de uma metodologia didática construtivista e investigativa, que parece ser bem acolhida pelos futuros professores, ao menos em plano declarativo, para que tenha uma maior incidência na prática profissional [...] (p.78) 
Pope e Scott (1983) têm como ideia central de seu trabalho que a concepção empirista das ciências está diretamente relacionada com a versão absolutista da verdade e do conhecimento, portanto os professores que possuem essas mesmas concepções, do conhecimento científico, não valorizam as concepções de seus alunos.

Para Mellado (2001) a mudança profissional em professores é inseparável de seu aspecto social, pessoal e de sua emoção, pois essa mudança só ocorre se houver uma compensação afetiva, onde o professor se torne mais satisfeito consigo mesmo e com seu trabalho. $O$ autor mostra que para o professor fazer mudanças em suas concepções e em sua prática, uma reflexão crítica deve acontecer. O mesmo autor, em trabalho mais recente (Mellado, 2003), faz uma revisão de várias investigações sobre o processo de mudança na prática pedagógica dos professores de ciências e para isso fez uma analogia com o processo de mudança científica, segundo algumas teorias da filosofia da ciência. Para professores em exercício cursos de aperfeiçoamento são pouco eficazes a não ser para aqueles professores que já estão predispostos a mudar, pois professores são bastante céticos em relação a modelos de reformas de ensino. Para o autor as mudanças acontecem mais pela discussão e a colaboração entre os participantes do grupo do que pela transmissão de novos modelos de ensino. Professores mudam quando se sentem insatisfeitos com suas concepções e práticas docentes diante das novas contribuições da investigação educativa. Essa insatisfação e conflito são necessários para mudanças, desde que não os levem ao desencanto e a frustração.

A emoção permeia todos os campos da educação seja nas concepções epistemológicas do professor, seja em sua prática, na disposição ao ensinoaprendizado de professores e alunos e nas possíveis mudanças de todos os envolvidos no processo cognitivo.

Essa relação entre conhecimento e emoção ou afetividade também é abordada por Morin (2003), que coloca intelecto e afeto em um mesmo eixo, em um mesmo nível de importância.

[...] o desenvolvimento da inteligência é inseparável do mundo da afetividade, isto é, da curiosidade, da paixão, que por sua vez, são a mola da pesquisa filosófica e científica [...] (p. 20). 
Os últimos levantamentos sobre as concepções epistemológicas do professor mostram uma visão empirista da ciência e uma desvinculação do conhecimento e da emoção por parte dos professores.

\subsection{As Concepções Epistemológicas de Humberto Maturana}

\section{O que é especialmente humano no amor não é o amor, mas o que fazemos no amor enquanto humanos.}

Humberto Maturana

Para o biólogo e epistemólogo chileno Humberto Maturana vida é um processo de conhecimento e por esse motivo para se entendê-la faz-se necessário compreender como os seres vivos veem o mundo.

Para Maturana o fenômeno do conhecer é uma integração entre o humano, o social e sua base biológica.

Ele nos mostra que não há como saber se o mundo é ou não do jeito que o vemos, construímos o mundo e somos construídos por ele, portanto somos responsáveis por nossas ações. E como seres humanos e me arrisco a dizer, como professores, somos convidados a sair do conforto e da passividade de nosso papel social para construir o mundo que queremos na educação.

Há no mundo uma visão generalizada de que conhecimento é a representação de uma realidade, resultado de um processamento de informações. $O$ que Maturana traz de novo é a ideia de que tudo o que é dito é dito por alguém, ou melhor, por um observador.

[...] Não vemos o "espaço" do mundo, vivemos nosso campo visual [...] (Maturana, 2001, p.28)

Para ele não se pode conhecer o conhecer sem conhecer o conhecedor. Esta recursividade está presente o tempo todo em suas ideias.

Quando Maturana diz que tudo o que é dito é dito por um observador ele não exclui a validação das explicações para que sejam aceitas.

[...] Uma explicação é sempre uma proposição que reformula ou recria as observações de um fenômeno, num sistema de conceitos aceitáveis para 
um grupo de pessoas que compartilham um critério de validação[...] (Maturana, 2001, p.34)

Para ele cada explicação está de acordo com a visão de mundo de cada observador, com sua história de vida, crenças e valores. $O$ autor sustenta que conhecer é uma ação efetiva que permite a um ser vivo existir e continuar existindo em um meio, possibilitando assim o surgimento de seu mundo. Tem como ponto de partida que todo conhecer é um fazer daquele que conhece, portanto depende de sua estrutura, de sua organização. E para ele o que caracteriza o ser vivo é sua organização autopoiética.

Autopoiese é um conceito utilizado por ele para descrever organismos que se autogerem, se autoproduzem, indicando uma autonomia de ações e reações.

[...] A característica mais peculiar de um sistema autopoiético é que ele se levanta por seus próprios cordões, e se constitui como diferente do meio por sua própria dinâmica, de tal maneira que ambas as coisas são inseparáveis [...] (Maturana, 2001, p.55)

Ele caracteriza dois conceitos para o ser vivo: organização e estrutura. A organização diz respeito às relações que ocorrem entre os componentes de algo, ser vivo ou não, que o reconheça como parte de uma classe específica, já o conceito de estrutura é utilizado para designar os componentes e relações que configuram a organização de uma unidade particular.

Todo ser vivo é um sistema autônomo, "capaz de especificar sua própria legalidade" (Maturana, 2001, p.55), produzindo a si mesmo de modo contínuo. Os componentes celulares possuem uma rede dinâmica de interações, produzem componentes e integram a rede de transformações que os produzem. Essa recursividade ou circularidade está presente em todos os momentos na linguagem de Maturana.

As mudanças só ocorrem nessas unidades autopoiéticas através de interações com o meio, desde que estas mudanças estejam previstas em sua própria estrutura. Portanto, o meio não determina as mudanças, ele apenas as desencadeia. Para que essas mudanças estruturais ou de estado mútuas e concordantes ocorram é necessário um acoplamento estrutural.

Acoplamento estrutural é uma dependência da unidade com o meio, um vai desencadear alterações no outro. Organismo e meio interagem e essa interação é 
essencial para a manutenção do ser vivo, pois alteram um ao outro, lembrando que para o autor as mudanças só ocorrem se permitidas pela própria estrutura do indivíduo. A reação, a mudança, está no próprio organismo e é apenas desencadeada pelo meio.

Esse acoplamento estrutural é uma complementaridade estrutural entre o organismo e o meio, portanto é essencial para todo o sistema.

[...] Enquanto existir essa comensurabilidade, meio e unidade atuarão como fontes de perturbações mútuas e desencadearão mutuamente mudanças de estado [...](Maturana, 2001, p.112).

Podemos então entender a aprendizagem como mudanças estruturais que ocorrem através de interações com o meio, em um acoplamento estrutural contínuo, mantendo-se a adaptação do ser vivo ao meio.

O sistema nervoso, sendo parte do ser vivo, possui uma determinação estrutural, portanto podemos considerá-lo como um sistema fechado que não trabalha com representações do mundo. O meio ambiente não pode provocar mudanças nele e sim desencadear mudanças. Apesar de o sistema nervoso ser considerado fechado para captar informações, ele é aberto para o fluxo de estímulos.

Segundo Maturana, o sistema nervoso expande os domínios de interação de um organismo, pois a cada momento funciona de maneiras múltiplas, através de seus ciclos e interações em uma "mutação incessante" (Maturana, 2001, p.180).

[...] O que dissemos mostra que o funcionamento do sistema nervoso é plenamente consistente com sua participação numa unidade autônoma, na qual a todo estado de atividade leva a outro estado de atividade nela mesma, dado que seu modo de operar é circular, ou em clausura operacional. [...] (Maturana, 2001, p.185)

O autor distingue dois tipos de comportamentos: os inatos e os aprendidos. Os comportamentos inatos são aqueles independentes de interações e diz que são geneticamente determinados, instintivos. Os comportamentos aprendidos ocorrem se há uma história de interações entre as estruturas que passam a ser chamadas de ontogenéticas. Acreditamos que o comportamento em sala de aula é aprendido e, portanto professores e alunos precisam de uma história de interações. 
Esse acoplamento estrutural entre organismos ocorre no dia a dia escolar, onde um organismo é fonte de perturbações para o outro e essas interações são recorrentes e levam a coordenações consensuais de condutas, as quais Maturana chama de linguagem ou linguajar. É através da linguagem que o ser humano se constitui e mantém os sistemas sociais. Essa coordenação de conduta sobre coordenação de conduta leva a um mundo de ações e reflexões que só tem sentido em um domínio social.

[...] Somos concebidos, crescemos, vivemos e morremos imersos nas coordenações de condutas que envolvem as palavras e a reflexão linguística, e por e com ela na possibilidade da autoconsciência [...] (Maturana, 1997, p.203)

Para Maturana o genético apenas funda o que ele chama de humanizável, pois o ser humano só existe no social, num fenômeno de coexistência. E este social se funda no amor, ou para sair de possíveis chavões, consiste na abertura de espaço onde se veja o outro como legítimo outro, levando-se em conta o respeito e a cooperação.

[...] O amor é o fenômeno biológico que nos permite escapar da alienação anti-social criada por nós através de nossas racionalizações [...] (Maturana, 1997, p.185)

As emoções são disposições corporais que especificam o domínio de ações de um animal, humano ou não. As emoções permitem as interações entre organismos e o meio. Entre todas as emoções, o amor é a emoção que move o social, que envolve o outro em suas coordenações consensuais de condutas.

O fluir de nosso emocionar muda o domínio de ações e com isso muda o nosso linguajar e o nosso raciocinar. Daí a importância de se manter o acoplamento estrutural social, onde o outro também tenha lugar, que nos permita refletir e ampliar nosso campo de visão, onde possamos ver com uma perspectiva mais ampla e agir com responsabilidade.

[...] É nossa história de interações recorrentes que nos permite um efetivo acoplamento estrutural interpessoal. Permite-nos também descobrir que compartilhamos um mundo que especificamos em conjunto, por meio de nossas ações [...] (Maturana, 2001, p.255).

Para Maturana qualquer atitude que destrua a aceitação do outro, seja através de competições, certezas ideológicas ou a posse da verdade destrói o 
fenômeno social e sem a socialização não há humanidade. Infelizmente essas atitudes são frequentes em sala de aula.

A existência humana parte do emocional e realiza o racional através da linguagem, das interações com o outro, das coordenações consensuais de condutas.

[...] Todo sistema racional tem fundamento emocional, e é por isso que nenhum argumento racional pode convencer ninguém que já estivesse de início convencido, ao aceitar as premissas a priori que o constituem [...] (Maturana, 1997, p.171)

O professor precisa entender que as emoções e o linguajar se entrelaçam, isto é, se modulam continua e mutuamente na convivência de sala de aula. Por este motivo é fundamental que o professor, através da linguagem, saiba guiar o emocionar do aluno a uma reflexão. Através da linguagem ou da conversação, é que o professor abre caminhos para a reflexão, onde seu aluno possa ser respeitado como legítimo outro e não se sinta negado por suas dificuldades.

Maturana nos mostra a intrínseca relação entre as emoções, a linguagem e a razão durante uma conversação e isso nos remete mais uma vez para dentro da sala de aula. Portanto, na tentativa de compreender o papel da emoção, da linguagem e da razão para professores de ciências nós as utilizaremos como três categorias teóricas a serem estudadas neste trabalho.

\subsection{A Respeito da Emoção}

A dicotomia entre razão e emoção interpretada por muitos autores a partir do método cartesiano está cada vez mais fragilizada, pois é evidente que não conseguimos dissociar a razão da emoção, nem torná-las antagônicas. Cada um dos nossos pensamentos, o nosso discurso e a nossa tomada de decisões está associada à emoção ou às emoções que atuam no momento.

Para Piaget (2005) em cada nível de desenvolvimento mental há um paralelismo entre comportamentos cognitivos e afetivos, sendo impossível encontrar comportamentos unicamente afetivos sem elementos cognitivos e vice versa. Para o autor a afetividade pode causar aceleração ou retrocesso no desenvolvimento da 
inteligência podendo modificar seu funcionamento e conteúdos, sem modificar ou produzir suas estruturas.

[...] elementos cognitivos e elementos afetivos se interpenetram estreitamente nas mais diversas situações [...] (Piaget, 2005, p.27)

Para este conceituado epistemólogo fica evidente, em seus estudos cognitivos, o papel da emoção, pois nos quatro estágios de desenvolvimento cognitivo propostos por ele, a saber, o sensório-motor, pré-operacional, operatórioconcreto e operatório-formal a emoção está presente, permitindo ou não a construção do conhecimento. Piaget cita a mudança de funcionamento e conteúdos na inteligência, desencadeadas pelas emoções. Neste aspecto, podemos estabelecer uma analogia com os conceitos de estrutura e organização de Maturana, onde a estrutura do ser vivo pode ser mudada, através de acoplamento estrutural com o meio ou com outro ser vivo, desde que não modifique sua organização.

Ao considerar a importância das emoções para o desenvolvimento humano e a impossibilidade de separar estas da razão é necessário levar esta reflexão para a escola, não apenas considerando o professor, mas também todos os sujeitos que entram em relação na sala de aula: alunos e professores. A este respeito Zembylas (2004) enfatiza que se deve levar em conta as contribuições ativas das crianças para a negociação de regras emocionais de sala de aula e significados na ciência, não considerar apenas o professor como aquele que impulsiona este processo.

Na pesquisa fica evidente a perspectiva de que as emoções são pelo menos tão importantes quanto o processo cognitivo na aprendizagem da ciência. Existe uma interdependência de emoção e cognição na aprendizagem da ciência, logo o desenvolvimento de habilidades e práticas intelectuais das crianças está diretamente relacionado ao tom emocional da sala de aula.

Freire (1996) propõe:

[...] Nenhuma formação docente pode fazer-se alheado a, de um lado, do exercício de criticidade que implica a promoção da curiosidade ingênua à curiosidade epistemológica, e do outro, sem o reconhecimento do valor das emoções, da sensibilidade, da afetividade, da intuição ou adivinhação [...] (p.51). 
Morin (2003) relaciona inteligência e afetividade, como a curiosidade e a paixão, e diz que a capacidade de raciocinar pode ser prejudicada pelo déficit de emoções.

[...] O enfraquecimento da capacidade de reagir emocionalmente pode mesmo estar na raiz de comportamentos irracionais [...] (p.20)

Novak (apud. Moreira, 1999) assume que a aprendizagem significativa ocorre com o intercâmbio entre pensamentos, sentimentos e ações e essa interação leva ao empowerment humano, ou seja, seu engrandecimento.

Tanto para Morin (2003) quanto para Novak (apud. Moreira, 1999) as emoções não só criam o clima de interações em sala de aula, como também tornam o indivíduo capaz de raciocinar e agir com responsabilidade evitando os comportamentos irracionais.

Para Santos (2007) os eventos emocionais nas interações em sala de aula servem para formar o clima e para favorecer a comunicação de significados entre alunos e professores, permitindo também uma orientação cognitiva. Em seu trabalho a autora discute a estreita interdependência entre afetividade e significação sob a ótica dos aspectos emocionais que orientam as interações no cotidiano das aulas. Griffithis (apud. Santos, 2007) descreve a abordagem da construção social da emoção e discute a visão de que há várias respostas emocionais, as quais dependem da existência de modelos culturais.

Almeida (1999) declara ser necessário, para melhorar as interações, ou podemos dizer a socialização dentro da sala de aula, que o professor conheça o fenômeno emocional e não só cognitivo de seus alunos.

[...] Assim, a emoção consiste naquilo que une o indivíduo à vida social pelo que pode haver de mais fundamental na sua existência biológica [...] (Wallon, apud Almeida, 1999, p.28).

Tassoni (2000) propõe que é através da interação com o outro, através da afetividade, que a criança vai adquirindo avanços cognitivos.

Para Maturana (1997b) "o humano se constitui no entrelaçamento do emocional com o racional" (p.10). Para ele as emoções se diferenciam dos sentimentos por serem disposições corporais dinâmicas que definem os domínios de 
nossas ações, de nosso modo de agir, portanto se muda a emoção, muda também a ação.

Se estivermos em uma determinada emoção podemos aceitar argumentos que provavelmente não aceitaríamos se estivéssemos sob outra emoção, "o que mudou são as premissas fundamentais da argumentação que se aponta. E essa mudança é emocional'. (Maturana 2001b, p.48). Isso nos faz compreender como a dinâmica em uma sala de aula pode ser transformada se conseguirmos, como professores, desencadear mudanças no fluxo das emoções.

[...] dizer que a razão caracteriza o humano é uma viseira, e o é porque nos deixa cegos frente à emoção que cai desvalorizada como algo animal ou como algo que nega o racional [...] (Maturana, 1997b, p.8).

\subsubsection{A emoção fundamental do humano: o amor}

Entre as emoções a que fundamenta o ser humano é o amor. Para Maturana o amor é um fenômeno biológico, que abre espaços para as ações, permite as coordenações consensuais de conduta, pois permite aceitar o outro como legítimo outro junto a nós. O amor é o fundamento do social, porque ao permitir a coexistência do outro conosco, permite a nossa socialização através da linguagem e, portanto, é o amor que permitiu nossa história evolutiva. A negação deste amor causa sofrimento, já que o amor faz parte de nosso fundamento biológico e humano.

É importante salientar que nem todas as relações são sociais, Maturana nos mostra que relações como as de trabalho e de poder não são sociais, pois exigem regras que fundamentam as coordenações de condutas.

Méndez (1993) acredita que surgimos do amor e dependemos dele, pois faz parte de nossa biologia, e quando o negamos culturalmente colocamos limites na convivência com o outro, em função de outras emoções. Para o autor inventamos discursos racionais para negar o amor e com isso negamos o outro. A linguagem deforma racional utiliza-se de emoções diferentes do amor.

Para que haja uma relação ou uma interação entre os seres humanos é necessário que o amor esteja presente, somos seres estruturalmente diferentes e precisamos de um espaço de aceitação recíproca para nos desenvolver. Neste momento abre-se espaço para refletirmos sobre a importância do amor em sala de 
aula, nas interações entre professores/alunos e aluno/aluno. Para que haja transformações, ou aprendizagens, a legitimação do outro é imprescindível. Ainda para Méndez (1993) é com o amor no centro das interações escolares que existirão paciência e respeito aos diferentes ritmos e maneiras de fazer dos alunos.

Como Maturana afirma é através do amor que recuperamos nossa humanidade.

Citando Freire (1996, p.46): "A assunção de nós mesmos não significa a exclusão dos outros".

\subsection{A Respeito da Linguagem}

É comum acreditar que a linguagem é um sistema de símbolos de comunicação, mas para Maturana os símbolos são secundários, surgem como distinções feitas pelo observador. Para ele linguagem não faz parte do corpo dos participantes, é um fluir de coordenações consensuais de condutas, de ações.

Para o autor o que permitiu a evolução dos seres humanos não foi a competição e sim a sua capacidade de colaborar uns com os outros, seja na troca de alimentos, cuidado com a prole, encontros sensuais ou na convivência através de coordenações consensuais de coordenações consensuais de condutas que constituem a linguagem.

[...] podemos identificar a característica-chave da linguagem, que modifica de maneira tão radical os domínios comportamentais humanos, possibilitando novos fenômenos, como a reflexão e a consciência [...] (Maturana, 2001, p.232).

Para Maturana não há como distinguir linguagem de emoção, pois elas se entrelaçam durante a conversação.

[...] Nestas redes fechadas de coordenações consensuais de emoções e linguagem, nossas ações e o fluxo de nossas ações na linguagem mudam ao mudarem nossas emoções, e nossas emoções e o fluxo de nosso emocionar mudam ao mudarem nossas coordenações de ações na linguagem [...] (Maturana, 2001b, p.132).

Essa linguagem como coordenações consensuais de condutas não pode surgir da agressão, pois atrapalha e restringe a convivência. Ela só é possível a 
partir do amor que permite ampliar a convivência e as interações recorrentes (Méndez, 1993)

A linguagem falada, para Vygotsky (2000), é regulada por situações dinâmicas que a motiva e a regula. $O$ autor afirma que em colaboração a criança faz mais, pois se revela mais forte e mais inteligente do que ao trabalhar sozinha, logo é na escola onde a criança aprende a fazer aquilo que não sabe fazer sozinha, com a colaboração do professor e sob sua orientação. Através de uma análise ontogênica e genética, sobre a linguagem e o pensamento, mostra que apesar dos caminhos serem diferentes, se cruzam em algum momento.

Para o autor o desenvolvimento do pensamento e da linguagem depende dos instrumentos de pensamento e da experiência sociocultural da criança, ou seja, o desenvolvimento da linguagem interior depende de fatores externos, onde o desenvolvimento da lógica na criança depende de seu domínio dos meios sociais do pensamento, o que ele chama de linguagem.

Ainda para Vygotsky (2000) a linguagem não é um simples reflexo especular da estrutura do pensamento, razão por que não pode esperar que o pensamento seja uma veste pronta. A linguagem não serve como expressão do pensamento pronto. Ao transformar-se em linguagem o pensamento se reestrutura e se modifica. "O pensamento não se expressa mas se realiza na palavra. Por isto, os processos de desenvolvimento dos aspectos semânticos e sonoro da linguagem, de sentidos opostos, constituem a autentica unidade justamente por força do seu sentido oposto" (Vygotsky, 2000, p. 412).

\subsection{A Respeito da Razão}

A concepção que identifica o indivíduo com a razão (cógito) encontra as suas origens nos albores do pensamento filosófico com Parmênides, quem defende uma verdade ontológica: ser é o mesmo que pensar (Spencer e De Barros, 1993). Assim na Grécia antiga, através de Aristóteles, Platão entre outros filósofos já ficou definida a separação corpo/mente ou razão/emoção e a busca pela verdade. O conhecimento racional como conhecimento do real, sem comprovações empíricas, mas com princípios que norteiam as regras do pensamento, foi chamado de 
metafísica. Ao longo da história da Filosofia muitos pensadores identificaram o indivíduo com a razão, sendo de particular importância para as ciências naturais o pensamento de René Descartes, para quem a razão entendida como pensamento é uma atividade do indivíduo.

[...] A razão convertida em autêntica entidade metafísica não informa apenas o cogito, mas regula igualmente os domínios da extensão garantindo com isso a veracidade da dedução, na sua modalidade sintética ou progressiva [...] (Spencer e De Barros, 1993, p.4)

No mundo moderno, segundo Pádua (2004) a ciência busca uma interpretação matemática do real e, portanto busca a neutralidade do conhecimento científico. O método científico passa a apresentar a ordem e a medida, elementos fundamentais para a matemática e passa com isso ser item necessário ao conhecimento científico que busca a verdade. O método científico foi necessário para separar o que era da filosofia, ou do metafísico, do que era conhecimento científico e com esse método foi possível manipular a realidade a partir de uma base experimental.

Para Teixeira e Melaco (2010) entre os séculos XVI e XVIII uma das questões da ciência era a verificação do método científico, já nos séculos $X I X$ e $X X$ a ciência tinha como foco o controle de resultados esperados. Nesta época, no princípio do século XX um grupo de cientistas, que ficou conhecido como o Círculo de Viena, pertencia a um movimento filosófico, o positivismo lógico.

O positivismo lógico, segundo Oliveira (2009), definia o conhecimento através de critérios de identificação e separação daquilo que não era cognoscitivo. Utilizavam para isso a análise lógica da linguagem, de seus enunciados que "são entidades linguísticas indicativas de como são os fatos" (p.30). Para esta análise os positivistas lógicos precisavam de instrumentos que diferenciassem os enunciados científicos de outras entidades linguísticas.

Oliveira (2009) aponta na obra de Wittgenstein (1921) Tratactus LogicoPhilosophicus duas teses básicas: que os enunciados lógicos e matemáticos são independentes das expressões que os compõem e que o significado do enunciado estão intimamente ligados, ou como diz o autor "se reduz"" aos dados empíricos que determina a veracidade do enunciado, ou verificacionismo. 
[...] se a verificabilidade é logicamente possível, então, a conclusão deve ser verdadeira também [...] (Teixeira e Melaco, 2010, p.8)

Teixeira e Melaco (2010) defendem que Karl Popper rejeitou o verificacionismo, tão defendido pelo Círculo de Viena, como sendo um critério de demarcação, isto é, entre o conhecimento científico e o não-científico. Para os autores o falsificacionismo de Popper vem contra a tese do empirismo lógico, sobre o método indutivo. O falsificacionismo propõe que uma teoria só é científica se for "corroborada e falsificada pela experiência passada" (p.13).

Chalmers (1993), em seu livro O que é ciência afinal?, faz uma introdução elementar sobre as concepções modernas da natureza das ciências e desenvolveu relatos sobre ciências. Insiste que não existe uma única categoria de ciência, pois não há como incluir várias áreas de conhecimento como a biologia, a física, a sociologia em uma única categoria. O autor demonstra um aspecto relativista e também objetivista. Quando Chalmers (1993) menciona que cada área do conhecimento pode ser analisada "por aquilo que é" (p.210), de acordo com seus objetivos e os meios usados para atingir esses objetivos, sendo julgada por seus próprios méritos ele apresenta uma visão relativista da ciência. No momento em que ele enfatiza:

[...] os indivíduos em sociedade são confrontados por uma situação social com certas características, estejam ou não cônscios disso, e têm à sua disposição uma variedade de maneiras de mudar a situação, quer gostem ou não [...] (p. 211)

Fica explícita sua visão objetivista da ciência. Isso mostra que não há um conceito universal e atemporal de ciência ou de método científico.

A visão do racionalismo clássico com as suas variações estende ao longo dos séculos e influencia a origem, os métodos e a finalidade do pensamento científico. Nesta perspectiva Spencer e De Barros (1993) afirmam que a razão absoluta é inimiga da tolerância da compreensão do outro e do verdadeiro respeito entre os homens. A esta razão absoluta identificada como racionalização por Morin (2003), se opõe a racionalidade "sempre insegura de seus resultados, e por isso mesmo modesta, ainda que disposta sempre a encontrar o melhor e eticamente mais correto, dentro da limitação essencial do humano" (Spencer e De Barros, 1993, p.15). 
Podemos afirmar aqui que a razão que Maturana nos apresenta como inseparável da emoção e da linguagem se aproxima e se identifica com a idéia de racionalidade de Morin (2003) e de Spencer e De Barros (1993).

[...] racionalidade deve se manter aberta ao que a contesta para evitar que se feche em doutrina e se converta em racionalização [...] (Morin, 2003, p.23)

[...] O exercício da racionalidade põe fronteiras à razão e lhe mostra que há um vasto domínio do mundo - certamente o maior - que é marcado pela irracionalidade. E, em lugar de proclamar, em abstrato, a soberania da razão, trata de tornar esse universo irracional o mais racional possível pelo trabalho constante e ininterrupto do entendimento [...] (Spencer e De Barros, 1993, p.15)

Morin (2003) coloca a racionalidade como a "melhor proteção contra o erro e a ilusão"p.23, pois a considera aberta a contestações para impedir que se torne doutrina. Ele diferencia racionalidade de racionalização. A racionalidade elabora teorias coerentes, verifica a compatibilidade entre ideias e a lógica da organização teórica, é aberta e autocrítica. Já a racionalização se crê racional, mas não aceita argumentos, ignora a subjetividade, a afetividade e, portanto pode se tornar fonte de ilusões. Para o autor a racionalização possui um sistema lógico perfeito e com isso nega a contestação de argumentos, como também à verificação empírica.

Até os dias de hoje a razão ocupa uma posição privilegiada em nossa cultura, e grande parte do processo de construção do conhecimento é dedicada a ela, a razão. Damásio (1996) em contrapartida propôs em seu livro "O erro de Descartes" que a emoção é parte integrante do processo de raciocínio, pois o auxilia.

Para Maturana a conduta racional é a maneira como operamos em explicações e argumentos e, portanto pertence às coerências operacionais das coordenações consensuais de conduta, a linguagem, que está associada à emoção. Para ele, negar que a razão tem como base a emoção é negar-se a ter responsabilidade sobre seus próprios atos racionais.

[...] é isentar-se por detrás da exigência de um real nunca atingido nem nunca provado, mas, que aceito a priori, coage o pensar, o agir e o viver coletivo [...] (Maturana, 1997, p.25). 


\subsubsection{Os caminhos explicativos de Maturana}

Maturana apresenta uma visão biológica do conhecimento. Somos conhecedores e observadores e como tal o somos através da linguagem, em contínua reflexão sobre o que nos sucede.

A relação do conhecer e da linguagem é tão íntima com a nossa biologia que ao alteramos essa nossa biologia, se alteram nosso conhecer e nossa linguagem.

Estamos sempre tentando explicar os fenômenos, as experiências, e com isso propomos uma reformulação de uma experiência para explicar de forma aceitável para o observador. Quem escuta a reformulação da experiência é quem decide se a explicação é válida ou não.

Configuramos o mundo que vivemos ao viver. Maturana parte do pressuposto que não podemos distinguir percepção de ilusão, portanto não podemos falar da realidade independente de nós mesmos, ele não descarta o objeto, apenas esse objeto não pode ser especificado independente do próprio observador. $\mathrm{O}$ autor destaca dois caminhos explicativos, um que ele chama de objetividade sem parênteses, e o outro da objetividade entre parênteses. No primeiro, o da objetividade sem parênteses, a explicação é dada como se o objeto, o fenômeno ou a realidade a que nos referimos fosse válido independente de nós mesmos.

Consideramos uma explicação objetiva, verdadeira e única. Levamos em consideração medidas, dados, tudo que possa comprovar a verdade, e a universalidade do conhecimento se funda nesta objetividade. Nesta objetividade sem parênteses não se leva em conta as habilidades cognitivas do observador, pois a realidade é independente dele.

Para Méndez (1993) esse caminho explicativo aparece como uma petição de obediência para o outro, onde a realidade objetiva ocorre independente do observador.

$\mathrm{Na}$ objetividade sem parênteses, acreditar que exista uma única realidade leva a conflitos entre observadores e as divergências entre eles ameaçam suas capacidades cognitivas levando a competições pela verdade e necessariamente a submissão do outro, negando-o, e gerando disputas. 
No segundo caminho explicativo, ou da objetividade entre parênteses, leva-se em conta as habilidades cognitivas do observador, não há verdade absoluta, pois todas as realidades são válidas, mesmo em domínios diferentes. Um domínio explicativo não anula o outro. Lembrando que para este autor "tudo o que é dito é dito por um observador".

Neste caminho da objetividade entre parênteses, a realidade não ultrapassa ao sujeito que a explica, todas as explicações são legítimas mesmo que não sejam igualmente válidas ou desejadas. Essa explicação é fundada na aceitação do outro como legítimo outro, ou seja, é fundada na emoção, no amor.

Qualquer explicação possui critérios explicativos, que as validam, e servem de convite para que o outro participe de seu domínio explicativo. Quando se trata da ciência há critérios de validação construídos por uma comunidade de observadores do campo da ciência (Méndez, 1993). Por mais que tentemos, não conseguimos dissociar esses três conceitos, emoção, linguagem e razão nas falas de Maturana, pois estão intrinsecamente relacionadas e são fundamentos um para os outros. 


\section{Objetivos da pesquisa}

O objetivo principal desta pesquisa foi investigar a Biologia do Conhecer de Humberto Maturana e as suas implicações educacionais para a relação pedagógica professor - aluno - conhecimento. Com os objetivos específicos se pretendia:

1. Conhecer as ideias que professores em exercício têm sobre a relação pedagógica: professor - aluno - conhecimento.

2. Identificar e comparar elementos encontrados nas respostas dos professores sobre a relação pedagógica com alguns elementos da epistemologia de Humberto Maturana, obtidas a partir de obras do autor. 


\section{Procedimentos Metodológicos}

Após analisar, selecionar e interpretar o pensamento e as ideias mais relevantes de Humberto Maturana na sua teoria da Biologia do Conhecer, e outros autores que deram consistência ao referencial teórico que sustenta a pesquisa, foi definido que este seria um estudo exploratório. A partir da revisão bibliográfica foram identificados três conceitos essenciais nas obras de Maturana, a saber, razão, emoção e linguagem (Tabela 1). Estes conceitos foram selecionados como categorias teóricas e utilizados como base para a elaboração do instrumento de pesquisa respondido pelos professores. Sob esse ponto de vista esta pesquisa é qualitativa e descritiva (Rampazzo, 1998) além de possuir uma etapa quantitativa que nos permitiu um panorama geral de nossa amostra de professores.

Definiu-se que para obtenção e interpretação dos dados seria utilizada a metodologia interativa-hermenêutico-dialética para pesquisa qualitativa descrita por Oliveira (2007). A escolha desta metodologia de análise se fundamentou na necessidade de ter uma visão sistêmica dialética e interacionista do problema e dos dados, e que segundo a autora permite uma visão do homem e da mulher como sujeitos que fazem e refazem a história, na busca de explicações para o entendimento da realidade que se pretende estudar.

Foi constituído um grupo de apoio com a ajuda de professores e colegas de pesquisa, todos da área do ensino de ciência. Este grupo de apoio respondeu ao pré-teste e fez críticas e sugestões ao instrumento de pesquisa.

O público alvo participante desta pesquisa foram 46 professores de ciências, de escolas públicas e particulares, que foram convidados a emitir as suas opiniões sobre afirmações a respeito da relação pedagógica professor/aluno/conhecimento, através de um opiniário.

O instrumento de pesquisa primeiramente foi um questionário do tipo Likert (Apêndice 1) com 20 questões que foi aplicado em um pré-teste a um grupo de 10 professores. Através desse pré-teste e com a ajuda inestimável do Prof. Dr. Esteban Tuesta estatístico da $\mathrm{EACH}$, chegou-se à conclusão que este tipo de questionário limita as possíveis respostas dos professores sendo necessário elaborar um questionário de notas (Apêndice 2) que permite graduar melhor a concordância ou 
não às questões, fornecendo um espectro maior de possibilidades de respostas para os participantes. Algumas questões que estavam confusas na sua interpretação foram reelaboradas para evitar problemas nas respostas. O questionário então foi reelaborado e finalmente ficou com 38 questões.

As frases do questionário de notas foram elaboradas considerando a inclusão das mesmas em alguma das categorias teóricas ou subcategorias previamente elaboradas, a intenção era analisar a adequação ou não adequação das respostas dos professores ao pensamento de Maturana (Apêndice 3). Este questionário de notas foi aplicado a 28 professores de ciências escolhidos por diversos critérios, por trabalharem ou terem trabalhado com a professora pesquisadora ou por escolha aleatória em visitas a escolas.

Cada professor deveria atribuir notas de 1 a 10 a cada uma dessas frases, sendo que a nota 10 era para a frase com a qual ele concordasse plenamente, a nota 1 para aquela frase que discordasse. Os valores intermediários deveriam ser utilizados para graduar sua concordância ou não com a frase. Estas notas foram tabuladas (Apêndice 4) e utilizadas para elaborar os gráficos que foram analisados de forma preliminar.

\subsection{Análise e discussão preliminar do questionário de notas}

Para esta etapa inicial de análise agrupamos os gráficos referentes aos mesmos temas, facilitando sua observação e sua análise.

A Figura 1 indica que, para grande parte dos professores, a razão é quem dirige nossos atos. Na Figura 2, quando usamos a expressão aspectos cognitivos, ao invés de razão, alguns professores não consideram que a cognição tem maior valor que a emoção, mas a grande maioria ainda sobrepõe os aspectos cognitivos à emoção, modificando um pouco as características do gráfico.

As Figuras 1 e 2 demonstram a grande tendência dos professores em considerarem a razão como fundamento de nossas ações e da formação de nosso conhecimento. 
Questão 1: Como seres humanos temos como diretriz de nossos atos a razão.

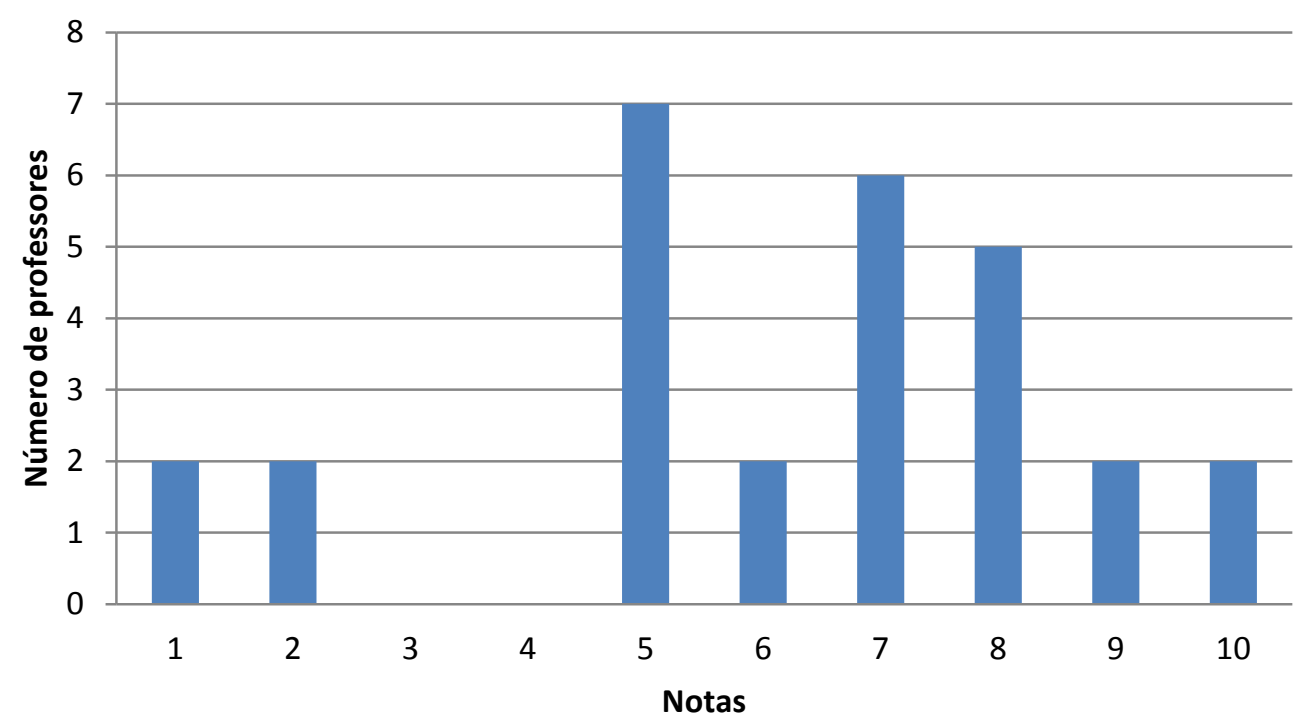

Figura 1: Representação gráfica das respostas dadas pelos professores à questão 1.

Questão 2: Os aspectos cognitivos da aprendizagem tem um valor maior em relação aos aspectos emocionais.

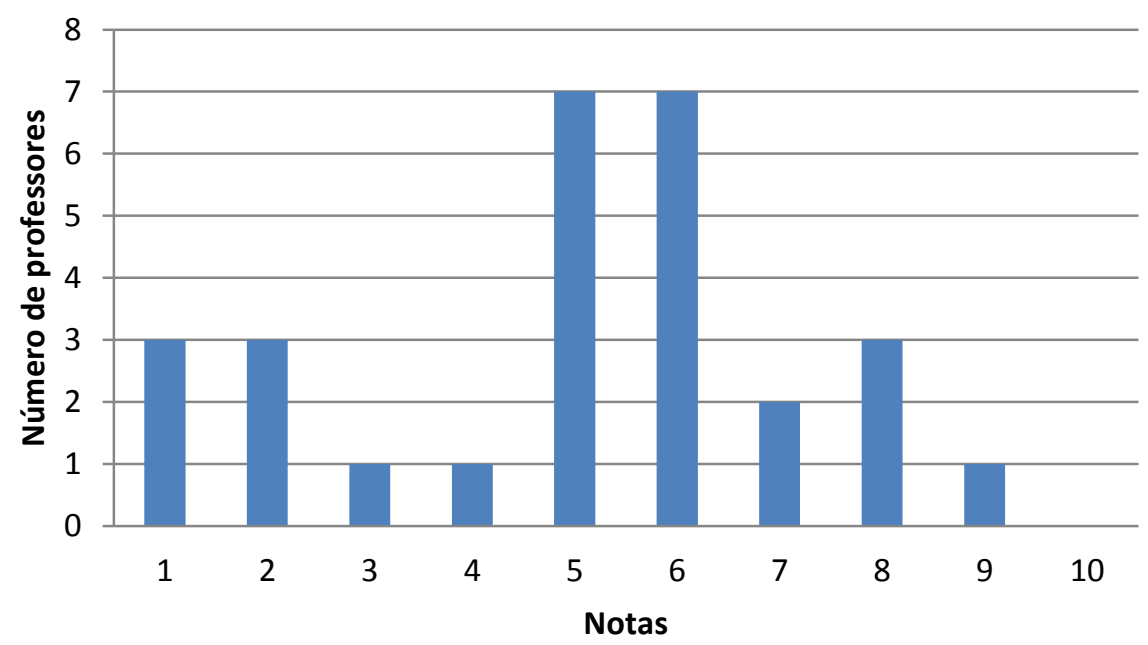

Figura 2: Representação gráfica das respostas dadas pelos professores à questão 2

Parece fazer parte do senso comum dos professores de Ciências que, por sermos seres humanos, nos diferenciamos dos demais animais pois pensamos. Maturana nos mostra que o ser humano se constitui no social através da linguagem, 
e o que nos diferencia de outros animais é justamente essa capacidade de interagir através da linguagem.

Apesar de oito professores não concordarem com a frase os demais professores tendem a aceitar que a aprendizagem ocorre quando o aluno presta atenção no professor. Podemos inferir que o professor é sujeito da educação.

Através das respostas dadas à questão 3 (Figura 3) podemos perceber que a ideia de "tabula rasa", onde basta o aluno prestar atenção no professor e escutá-lo para que ocorra a transmissão de conhecimento, persiste nos dias de hoje, independente do tempo de magistério do professor.

Questão 3: O aluno aprende quando presta atenção no professor.

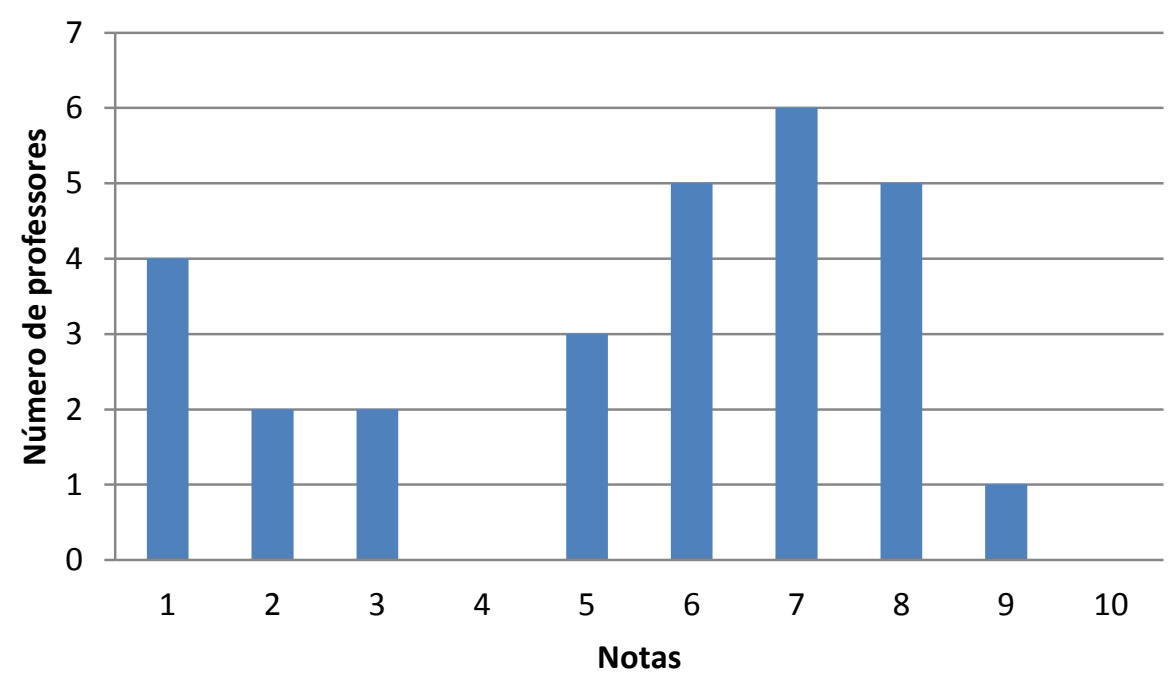

Figura 3: Representação gráfica das respostas dadas pelos professores à questão 3

A Figura 4 indica um grande número de professores (12) que não concordam que o professor é quem detém o saber científico, mas também podemos observar que, apesar da dispersão na concordância, outro grande grupo de professores (13) aceita esta afirmação.

Esta dispersão pode caracterizar o não entendimento da afirmação, pois, quando se fala sobre o saber científico, o professor pode ter direcionado aos cientistas e não a ele professor. 
Questão 4: O professor é o indivíduo que detém o saber científico.

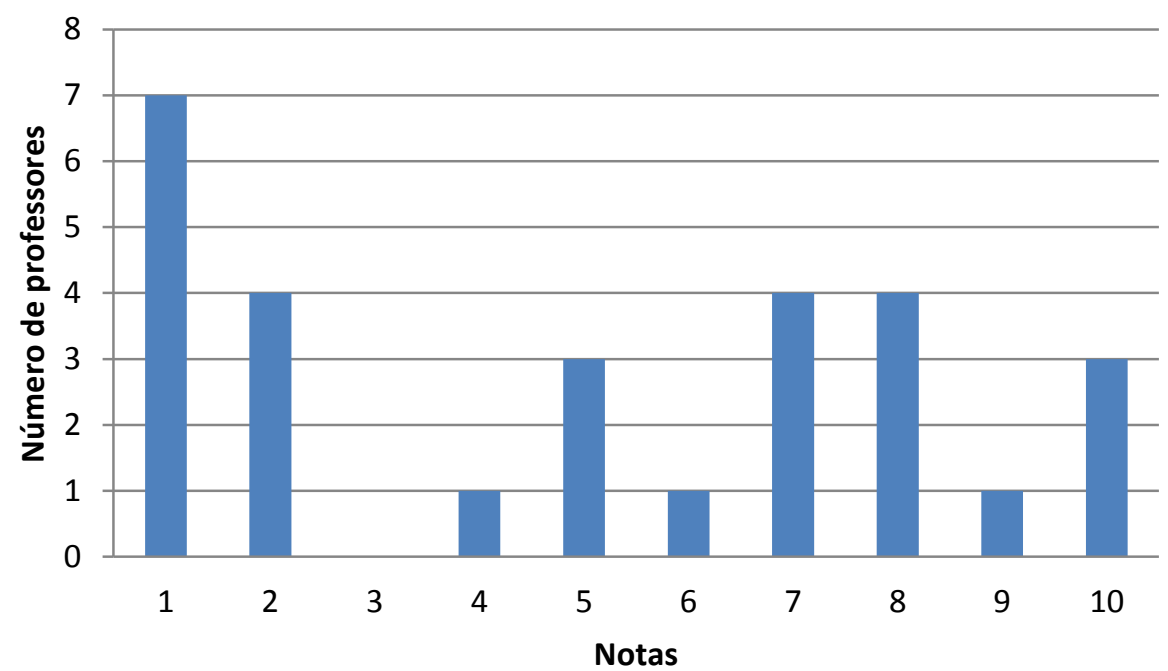

Figura 4: Representação gráfica das respostas dadas pelos professores à questão 4

Questão 5: Para que o conhecimento seja transmitido é necessária a atenção total por parte dos alunos.

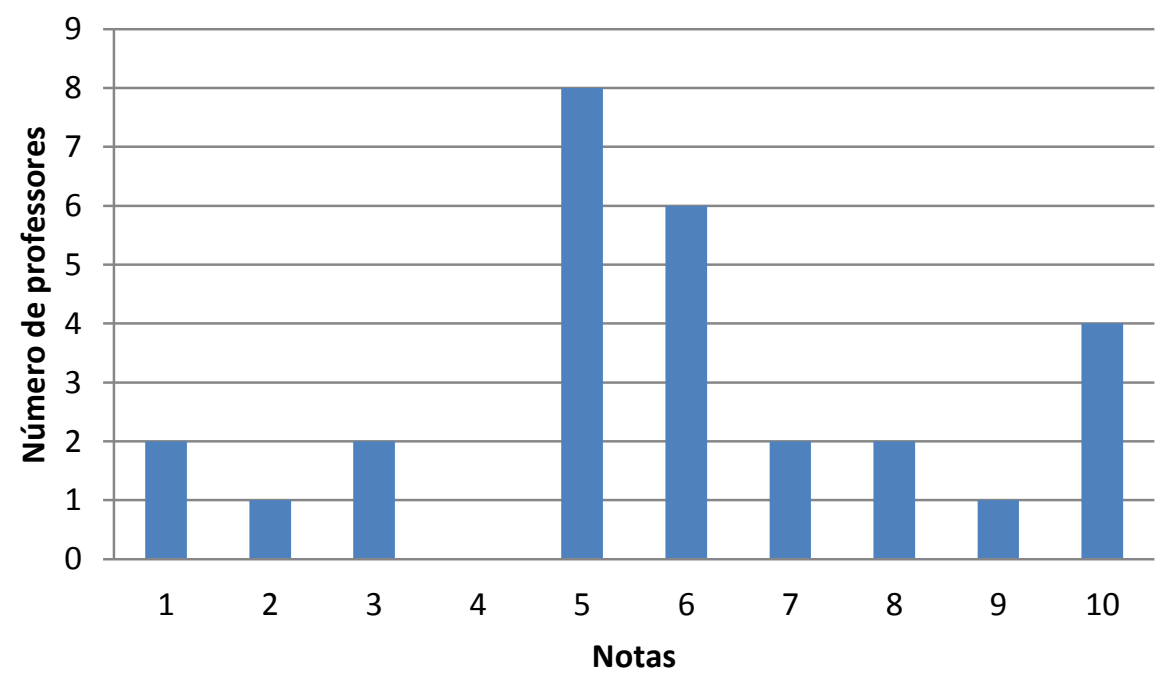

Figura 5: Representação gráfica das respostas dadas pelos professores à questão 5

A Figura 5 nos permite observar que muitos professores de ciências veem que a atenção é necessária para que o conhecimento seja transmitido.

Se compararmos o gráfico 6 (Figura 6) com o gráfico anterior (Figura 5) podemos observar que um número considerável de professores aceitam que é 
necessário a atenção total por parte dos alunos para que o conhecimento seja transmitido e aceitam a afirmação que na escola o conhecimento é transmitido.

Novamente encontramos dados nos gráficos contidos nas Figuras 4, 5 e 6 que nos indicam que na concepção dos professores o conhecimento é adquirido, ou seja, transmitido. Percebemos que o professor aparece como centro do processo educativo, provocando reações em seus alunos que passivamente recebe 0 conhecimento.

Questão 33: A escola é o local onde professor e alunos se encontram e, portanto é o local onde o conhecimento é transmitido.

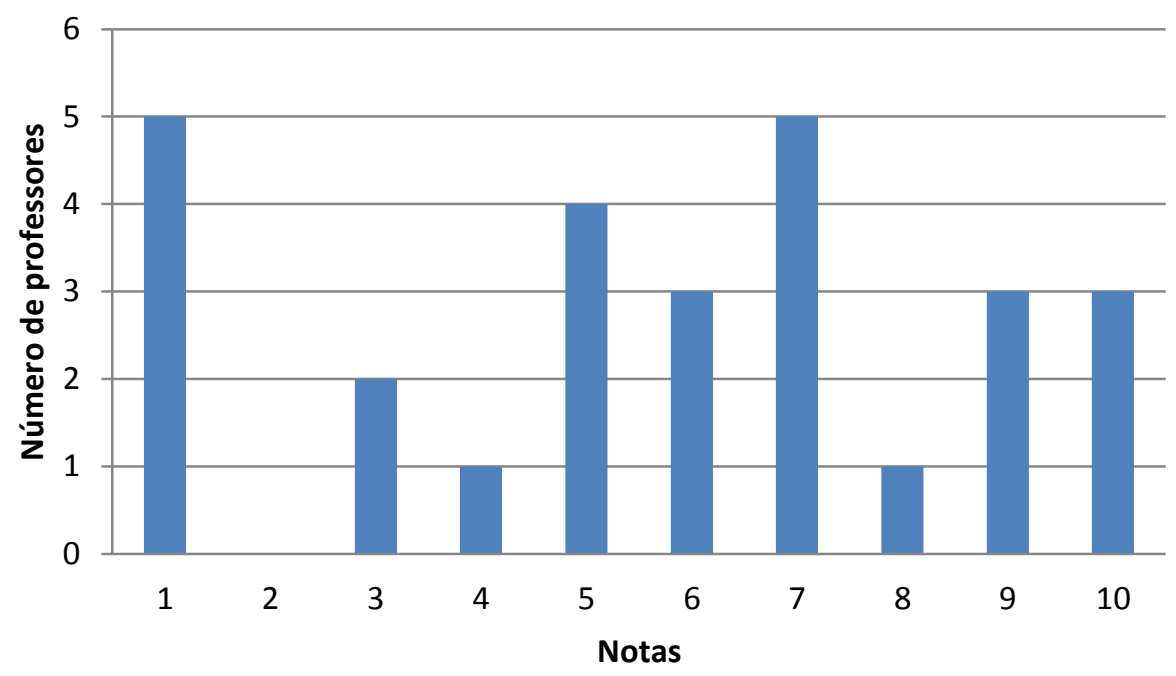

Figura 6: Representação gráfica das respostas dadas pelos professores à questão 33

Maturana nos mostra que o papel do professor é provocar perturbações que desencadeiem mudanças nas estruturas de seus alunos, porém essas mudanças só ocorrerão se a estrutura do próprio organismo assim o permitir.

A Figura 7 indica que, com exceção de um professor, o grupo pesquisado percebe a educação como um meio para que os alunos se tornem cidadãos responsáveis. Segundo nosso referencial teórico os seres humanos se constituem na emoção, e as emoções estão vinculadas com as tomadas de decisões. O papel do professor é abrir espaço na sala de aula para que a interação entre emoção e linguagem ocorra. Valorizando a emoção em sala de aula, o professor colabora para que seus alunos desenvolvam autonomia e com ela a responsabilidade. 
Questão 6: O propósito da educação é preparar nossos alunos para que se tornem cidadãos responsáveis e úteis à sociedade.

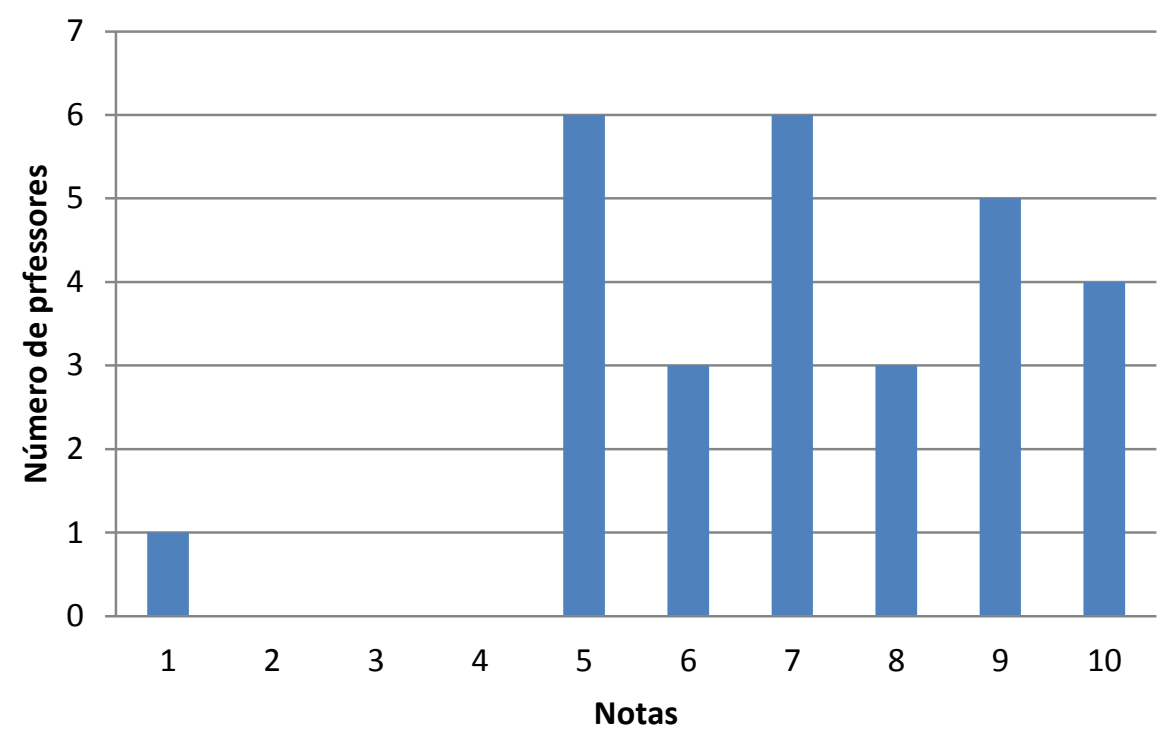

Figura 7: Representação gráfica das respostas dadas pelos professores à questão 6

Questão 7: O professor tem como dever transmitir seus conhecimentos aos seus alunos.

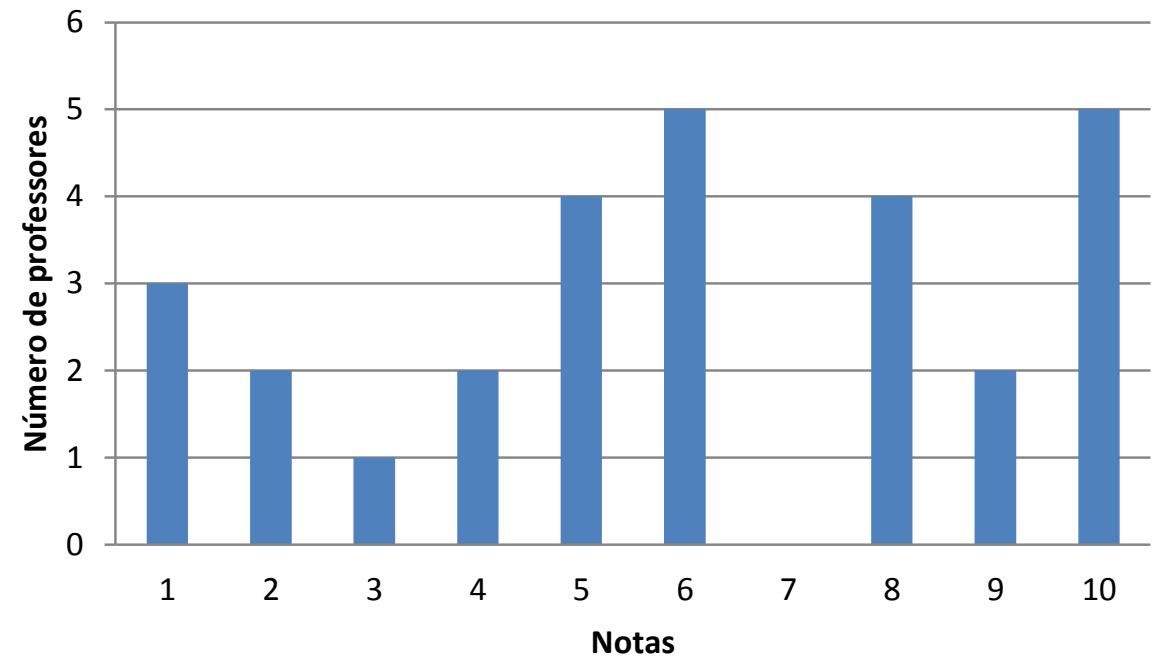

Figura 8: Representação gráfica das respostas dadas pelos professores à questão 7

O gráfico acima (Figura 8) indica que, apesar de alguns professores se posicionarem contra a afirmação, a maioria tende a aceitar que o papel do professor é transmitir conhecimento. 
Questão 8: As concepções ingênuas ou cotidianas dos alunos sobre ciência em geral são erradas.

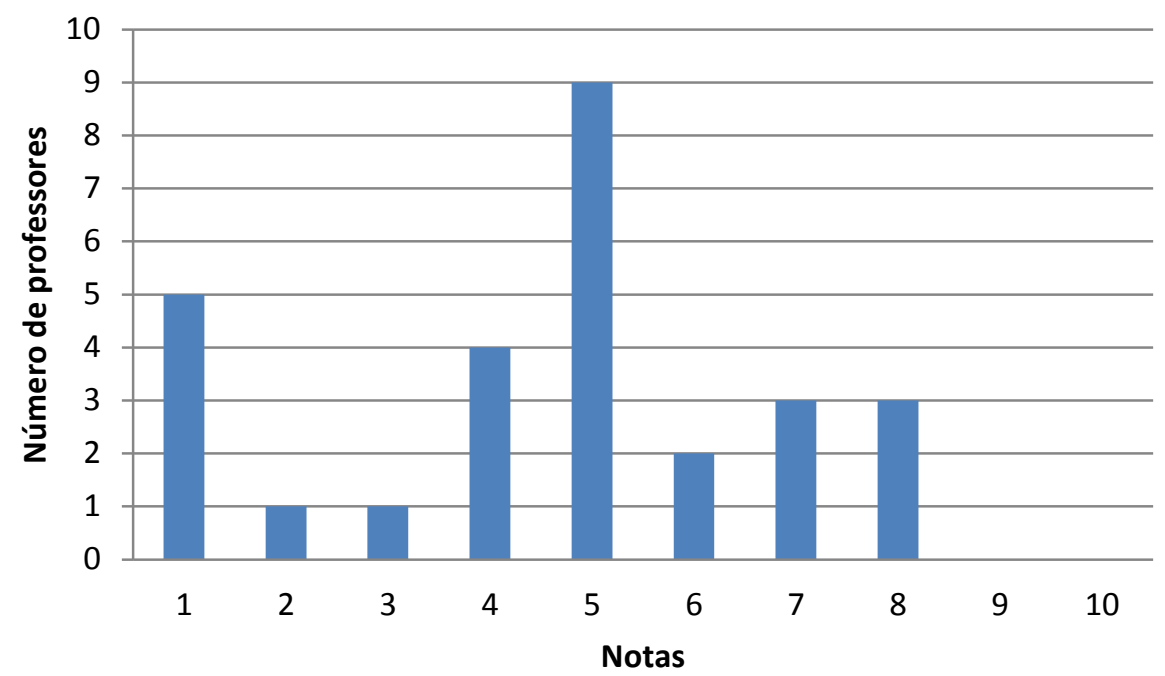

Figura 9: Representação gráfica das respostas dadas pelos professores à questão 8

Com relação à questão 8 (Figura 9), onze professores mostraram discordar que as concepções cotidianas dos alunos sobre ciência são errôneas, nove deles parecem não assumir uma posição a respeito desta afirmação e sete concordam com a frase.

Questão 13: $O$ professor por ser mais experiente e conhecedor do assunto tem como obrigação corrigir os conceitos errados dos alunos.

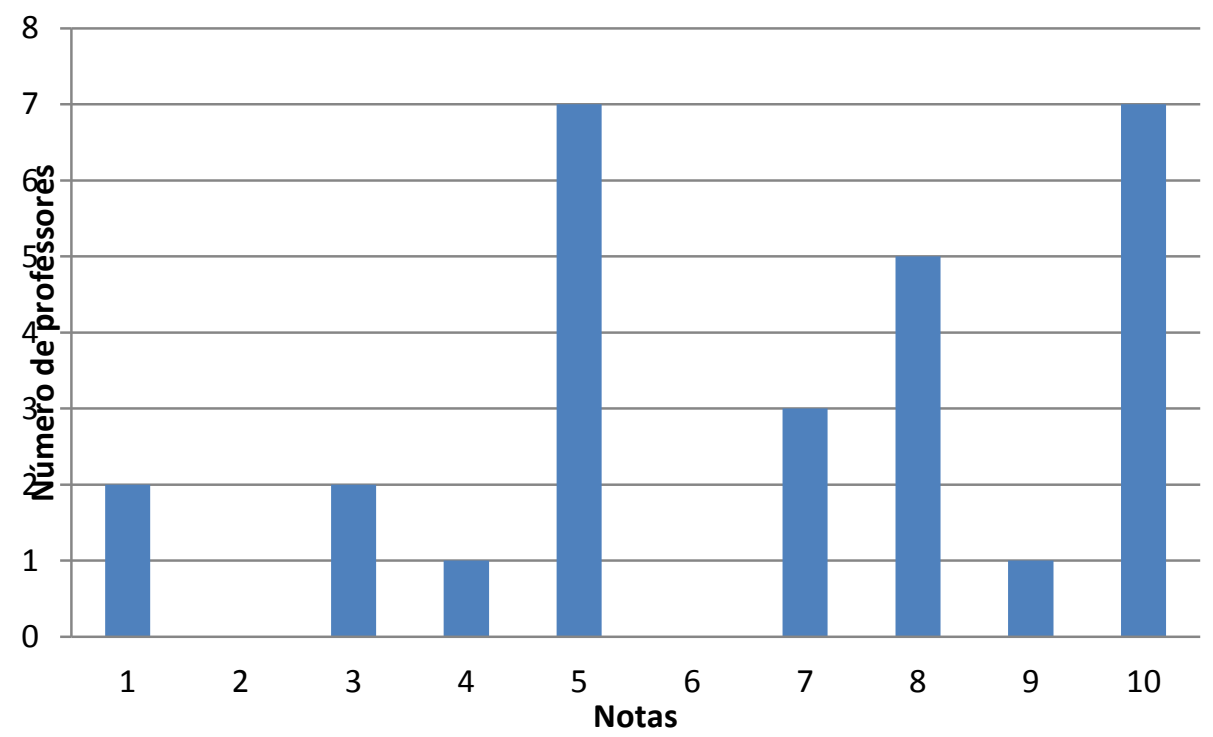

Figura 10: Representação gráfica das respostas dadas pelos professores à questão 13 
Para esta questão dezesseis professores concordam que o professor tem como obrigação corrigir os conceitos errados dos alunos, outros cinco professores discordam desta afirmação enquanto sete professores não se posicionaram claramente.

Com base nos gráficos contidos nas Figuras 8, 9 e 10 podemos inferi,r novamente, a ideia de transmissão de conhecimento do professor aos alunos, como se o professor fosse o único a deter conhecimento, além disso, os professores, em sua maioria, acreditam que as concepções que alunos possuem sobre ciências são ingênuas ou erradas.

Questão 9: As concepções ingênuas ou cotidianas devem fazer parte das discussões em sala de aula.

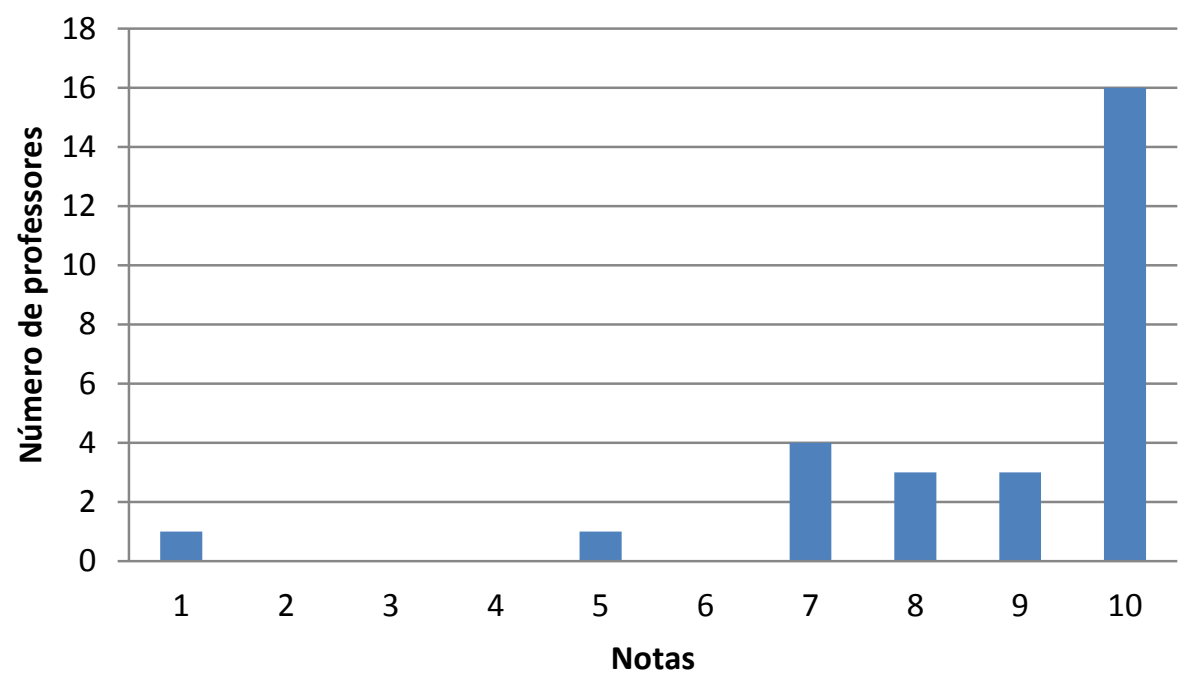

Figura 11: Representação gráfica das respostas dadas pelos professores à questão 9

Através do gráfico da Figura 11 verificamos que apenas um professor não aceita que as concepções cotidianas devem fazer parte das discussões em sala de aula enquanto maioria deles pensam ao contrário.

No gráfico 12 podemos observar que três professores tendem a aceitar que as concepções ingênuas sejam descartadas e se compararmos novamente com o gráfico anterior percebemos uma coerência entre os gráficos e, portanto entre as 
respostas. Professores acreditam que as concepções cotidianas dos alunos devem fazer parte das discussões em sala de aula e que não devem ser descartadas.

Questão 10: As concepções ingênuas ou cotidianas dos alunos devem ser descartadas.

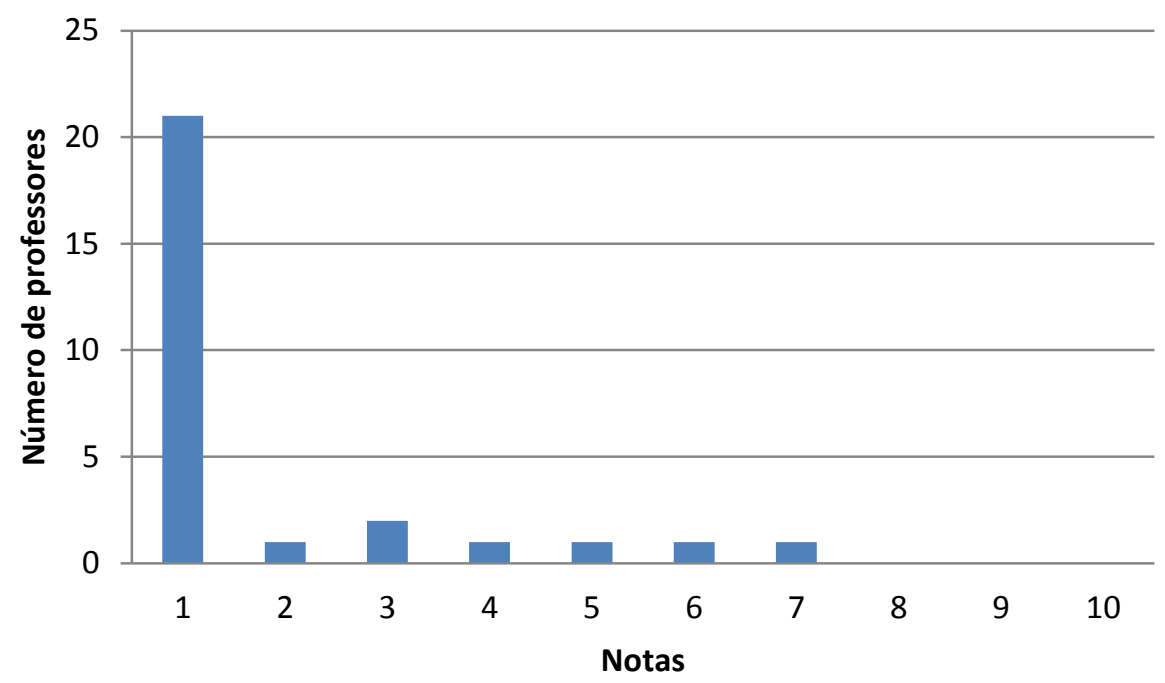

Figura 12: Representação gráfica das respostas dadas pelos professores à questão 10

Questão 11: O professor deve identificar um conceito errôneo para que não seja novamente utilizado por este ou outro aluno.

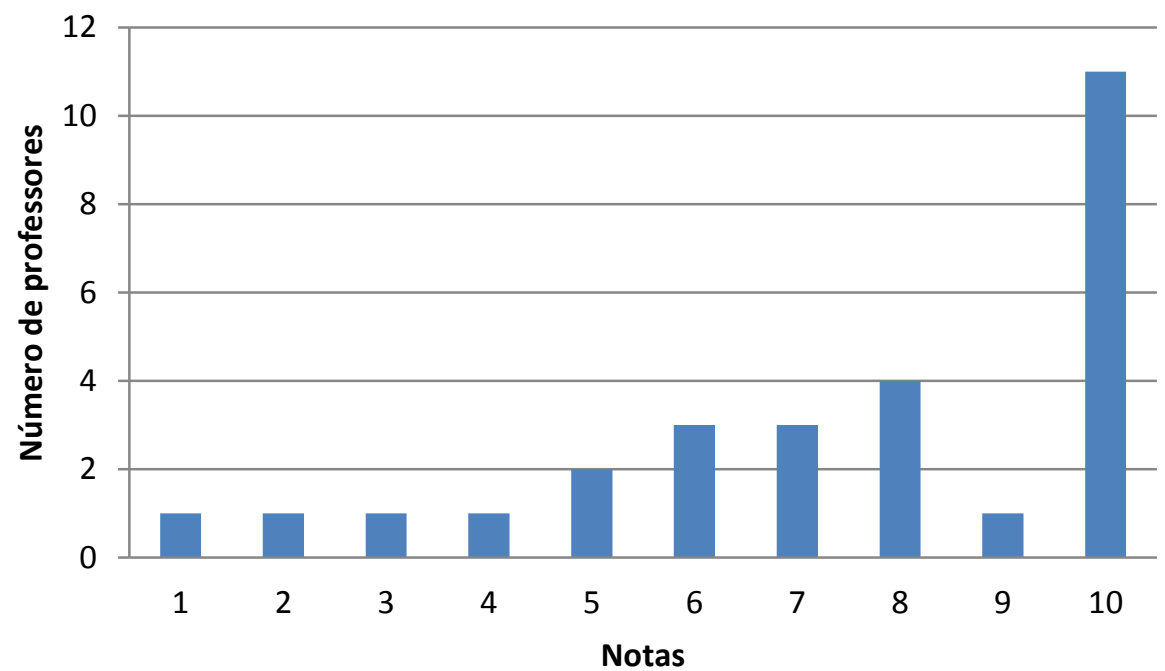

Figura 13: Representação gráfica das respostas dadas pelos professores à questão 11 
$\mathrm{Na}$ questão 11 (Figura 13) vinte e um professores concordam que os conceitos errôneos devem ser apontados e corrigidos, enquanto quatro professores discordam e dois não concordam e nem discordam totalmente. Essa resposta parece depender da concepção que o professor tem de conceito errôneo.

O professor, segundo Maturana, ao aceitar a existência de outras ideias a cerca de um assunto, mesmo que não concorde com elas, implica considerar a existência de vários domínios explicativos, o que faz com que seus alunos reflitam sobre suas próprias ideias, conservando-as ou não.

Questão 12: $O$ aluno que responder as questões do professor de maneira equivocada, provavelmente possui problemas de aprendizagem e deve ser encaminhado a outros profissionais.

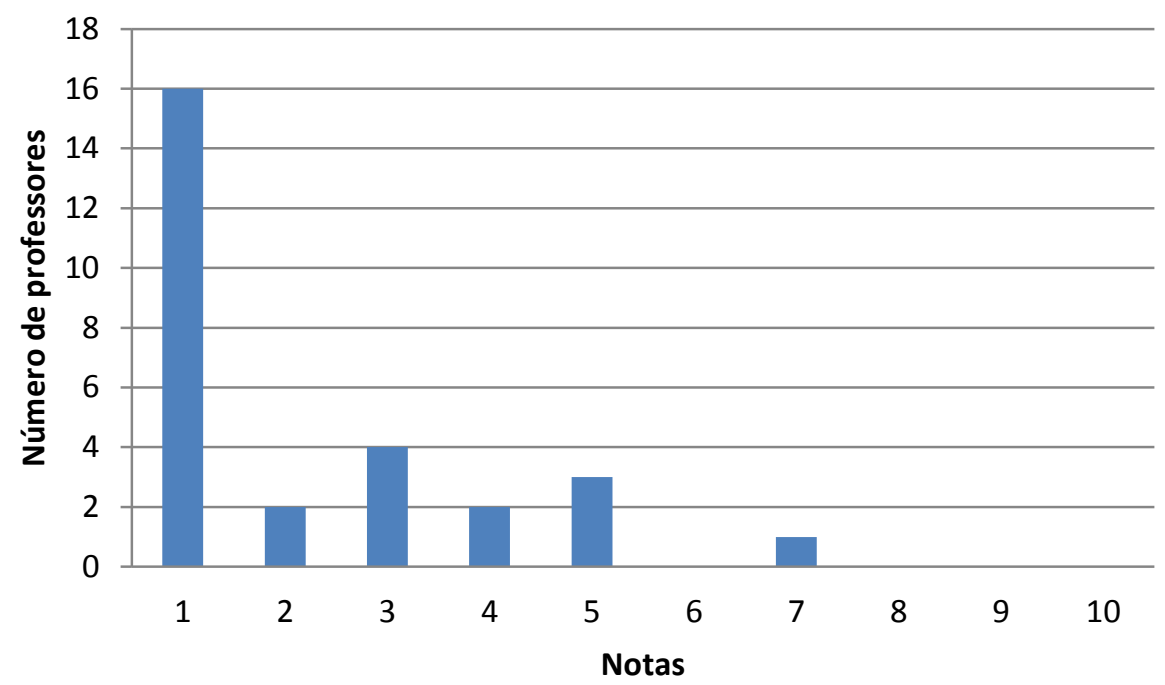

Figura 14: Representação gráfica das respostas dadas pelos professores à questão 12

Neste gráfico 14 podemos verificar que a maioria dos professores não considera que ao responder de maneira equivocada ou "errada" o aluno tenha problemas de aprendizagem necessitando de ajuda externa de outros profissionais, mas podemos observar que três professores ficaram indecisos com a afirmação e um professor se mostrou favorável a esta afirmação. É de senso comum entre professores que se os alunos não aprendem, por falta de interesse e não por problemas de aprendizagem. 
Maturana diz que a aprendizagem é uma mudança espontânea e não podemos garantir que ela ocorrerá na interação entre professor e aluno. No entanto, a intenção do professor em provocar mudanças mais a capacidade de enxergar o outro como um legítimo outro, abrindo espaço para uma conversação, desenvolvendo assim a confiança nesta interação, pode levar o aluno a refletir e mudar seu modo de raciocinar e agir.

Na questão 14 (Figura 15) a grande maioria dos professores parece acreditar que os conceitos de ciências devem fazer parte do cotidiano de seus alunos e um professor desta amostragem é contra esta ideia.

Questão 14: Aprender ciência é permitir que seus conceitos façam parte do dia a dia do aluno.

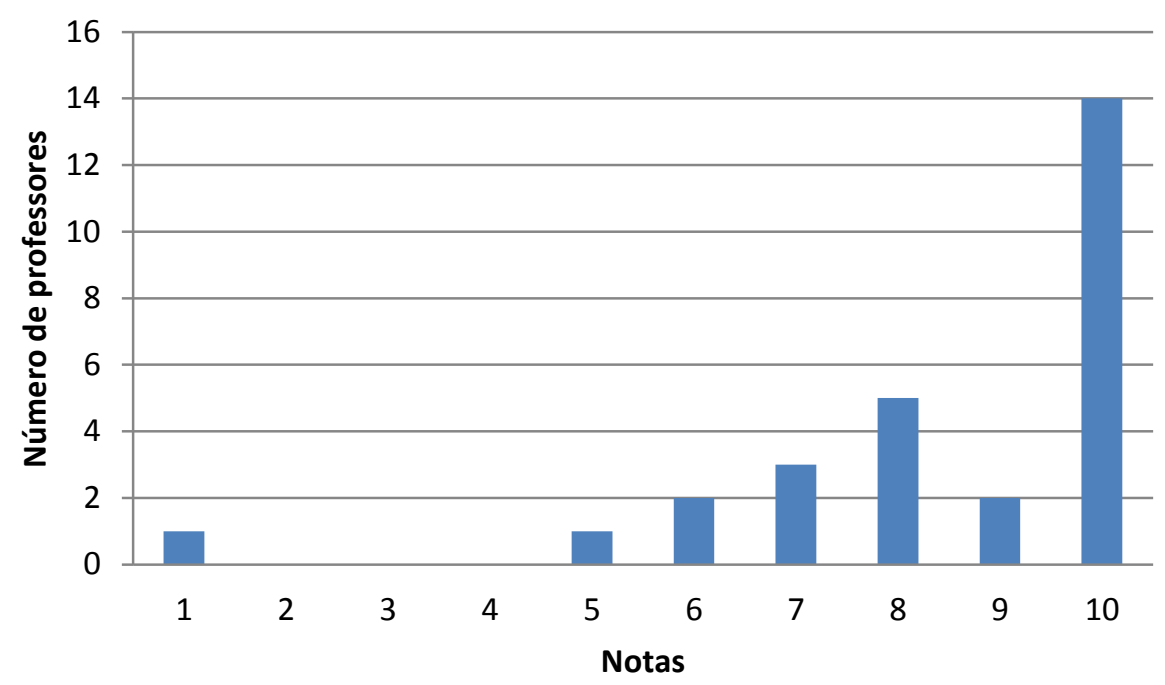

Figura 15: Representação gráfica das respostas dadas pelos professores à questão 14

Apesar da grande maioria de professores de ciências não aceitarem que a ciência é formada de conceitos únicos e verdadeiros, ainda podemos observar neste gráfico 16 que há professores que veem a ciência desta forma.

Da mesma forma que no gráfico da Figura 16, o gráfico da questão 16 (Figura 17) indica que a maioria dos professores vê a ciência como passível de incertezas e mudanças, mas uma pequena parcela de professores acreditam que a ciência não tem incertezas, são verdades absoluta. 
Questão 15: Ciência é formada por conceitos únicos e verdadeiros.

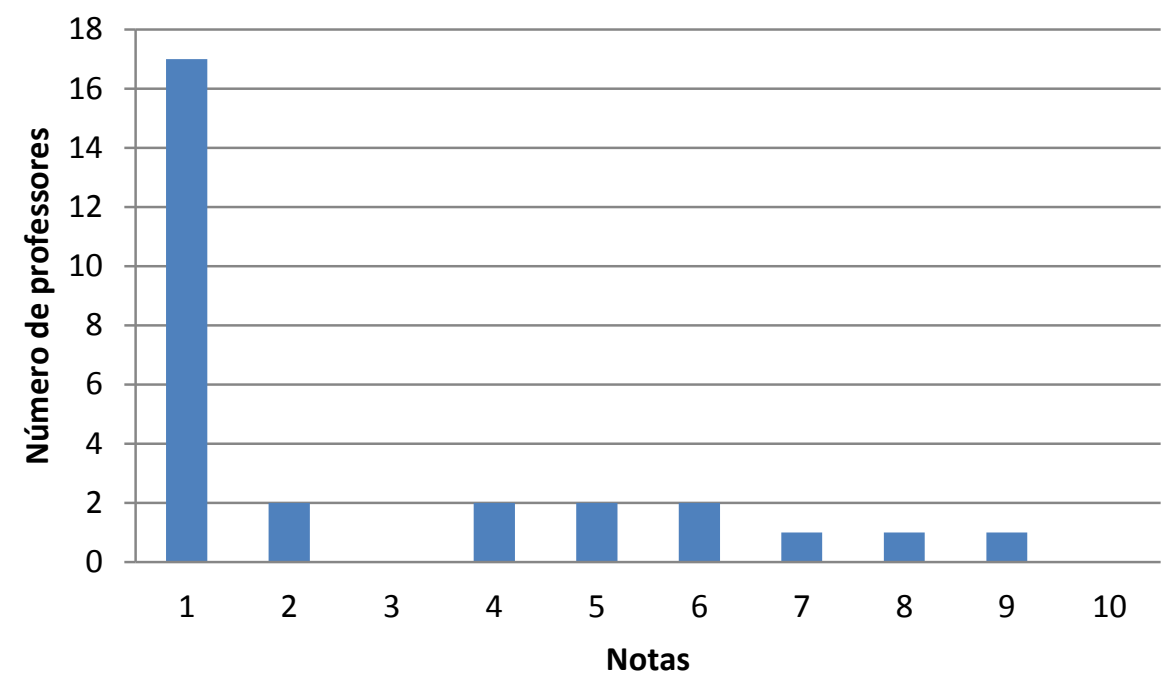

Figura 16: Representação gráfica das respostas dadas pelos professores à questão 15

Questão 16: Na Ciência não há incertezas.

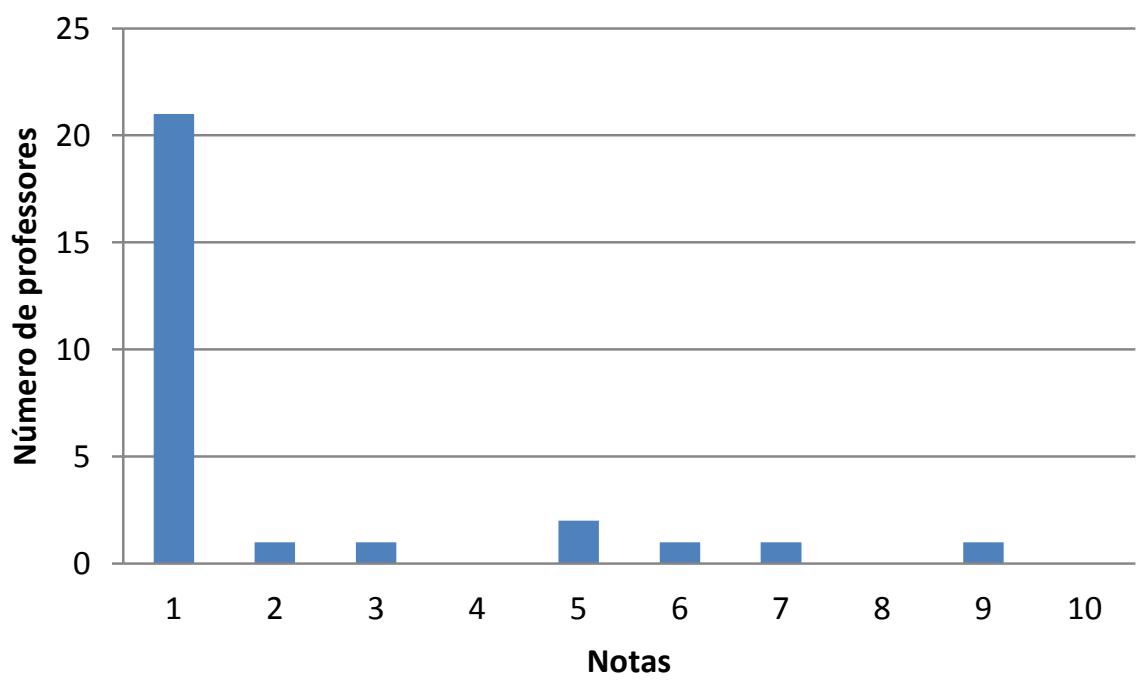

Figura 17: Representação gráfica das respostas dadas pelos professores à questão 16

Mais uma vez a maioria dos professores acredita que, da mesma maneira que a ciência tem incertezas, o ensino de ciência também as têm, mas ainda podemos observar um pequeno grupo desta amostragem que não vê as incertezas do ensino de ciências.

Os gráficos apresentados nas Figuras 15, 16, 17 e 18 nos permitem inferir que ainda há professores empiristas, pois apesar de acreditarem que, na ciência não 
há conceitos únicos e verdadeiros, uma parcela desta amostra acredita que no ensino de ciências não há incertezas o que nos indica que esses professores possuem uma concepção da natureza da ciência empirista, onde a ciência é única e verdadeira.

Questões 17: No ensino de ciência não há incertezas.

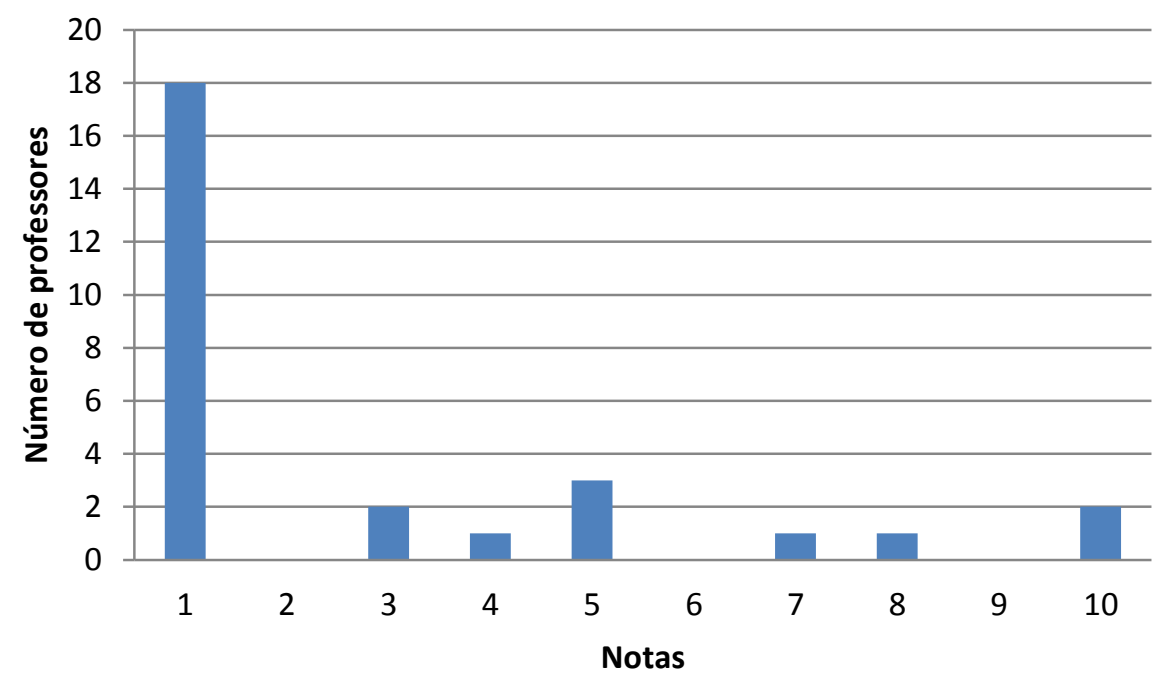

Figura 18: Representação gráfica das respostas dadas pelos professores à questão 17

Questão 18: Aprender ciência é permitir que seus conceitos sejam fonte de cultura e reflexão para o aluno.

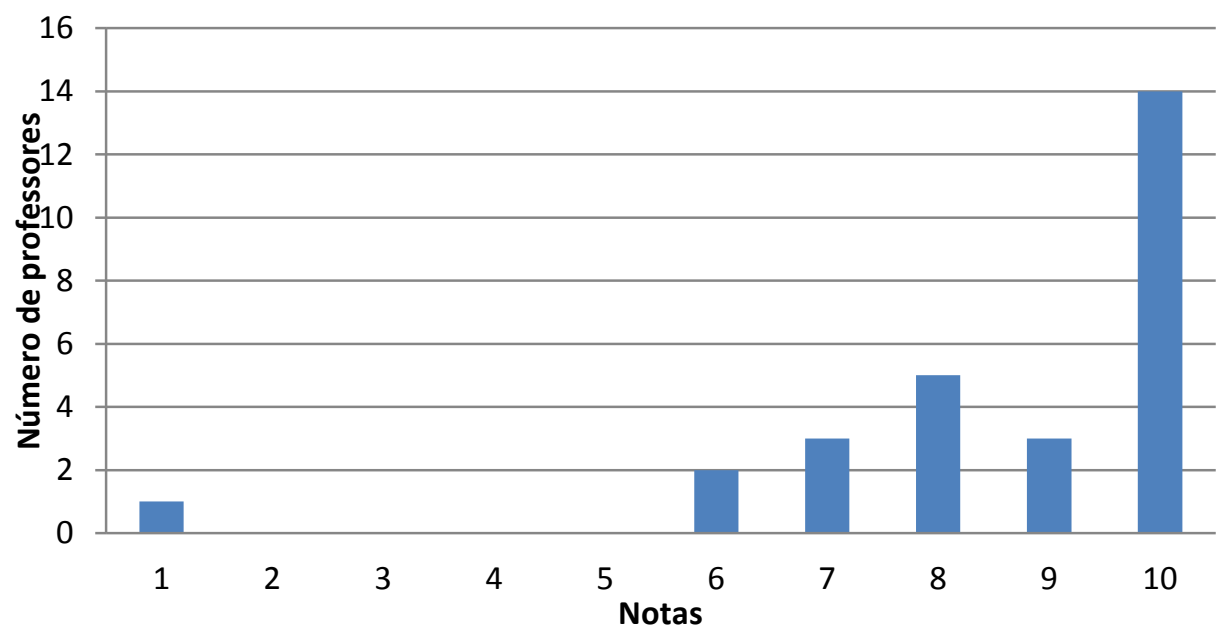

Figura 19: Representação gráfica das respostas dadas pelos professores à questão 18 
No gráfico da Figura 19 é nítida a aceitação por parte dos professores que ciência deve ser fonte de cultura e reflexão para os alunos, mas verificamos neste grupo um professor que se destaca dos demais.

Nos gráficos contidos nas Figuras 19 e 20 os professores aceitam que os conceitos da ciência são testáveis e transitórios e que devem fazer parte do dia a dia do aluno, mas podemos contrapor essas respostas com as dadas nos gráficos $16 \mathrm{e}$ 17 onde alguns professores consideram não haver incertezas na ciência.

Questão 19: A ciência possui conceitos testáveis e transitórios.

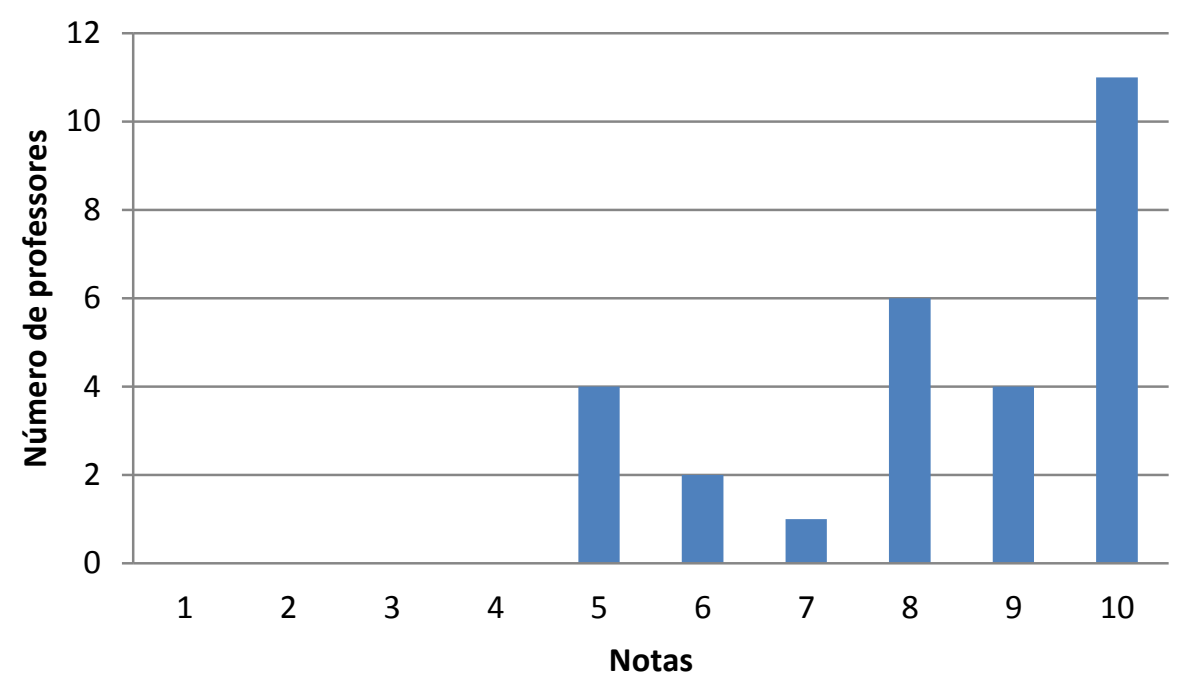

Figura 20: Representação gráfica das respostas dadas pelos professores à questão 19

$\mathrm{Na}$ Figura 21 podemos verificar que a grande maioria dos professores aceita que a emoção faça parte da tomada de decisões, mas vemos também que uma pequena parcela, apenas dois professores não aceitam que a emoção nos move e três professores parecem indecisos.

Verificamos no gráfico da Figura 22 que não há uma tendência única entre os professores a respeito da emoção como obstáculo à razão, mas uma boa parcela de nossa amostragem concorda com a afirmação.

Neste mesmo gráfico (Figura 22), com exceção de um professor que discorda e dois professores que ficaram indecisos quanto à afirmação, a grande maioria dos professores vê a emoção como fator necessário à aprendizagem. 
Questão 20: A emoção está associada à tomada de decisões

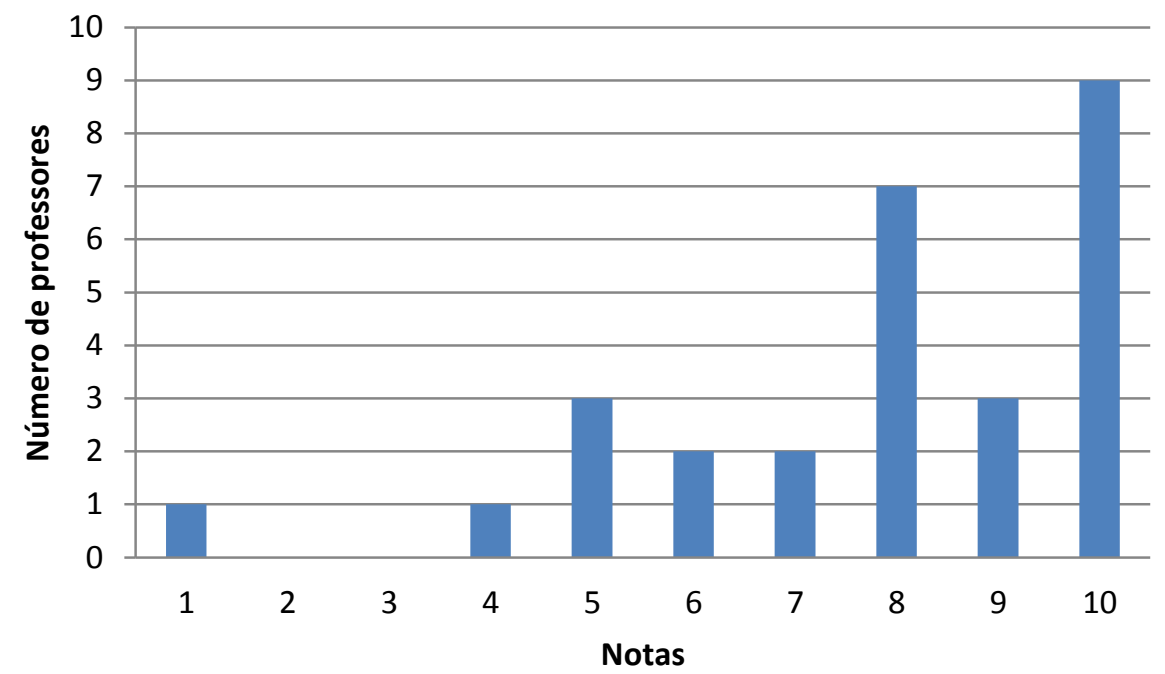

Figura 21: Representação gráfica das respostas dadas pelos professores à questão 20

Questão 21: A emoção é um obstáculo ao pensamento racional.

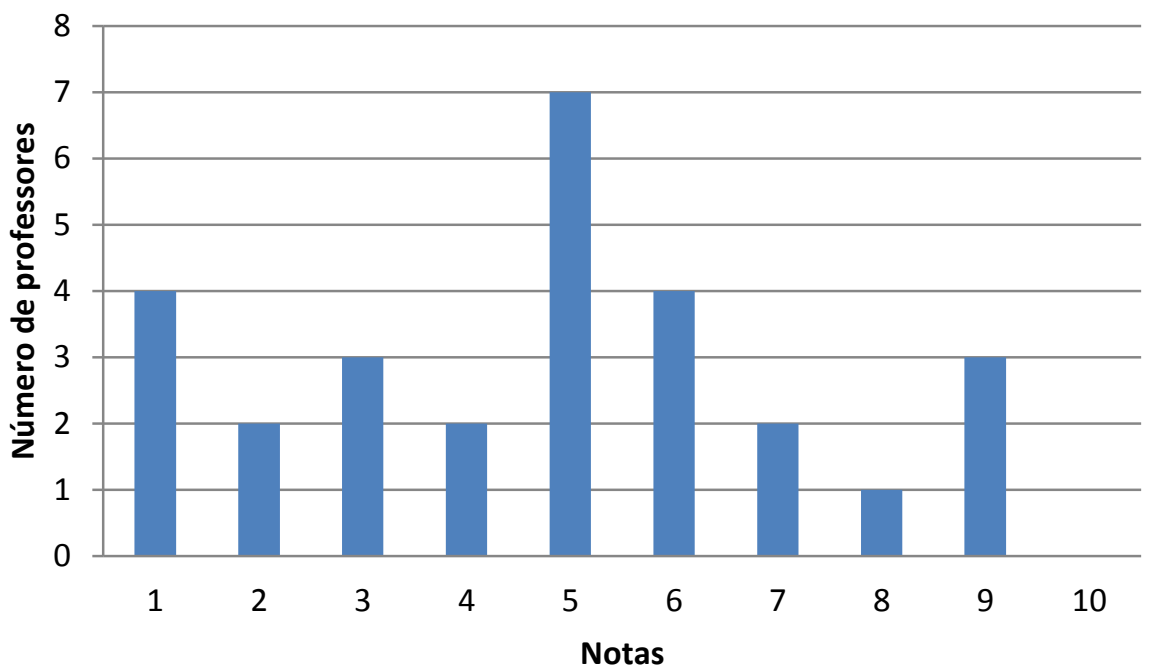

Figura 22: Representação gráfica das respostas dadas pelos professores à questão 21

O gráfico da Figura 24 indica que a autoestima, como um tipo de emoção, é vista como necessária à aprendizagem pela maioria dos professores, apesar de três professores estarem indecisos quanto a esta relação autoestima / aprendizagem.

No gráfico 25 percebe-se a tendência entre professores em aceitar que um dos papéis do professor em sala de aula é identificar as emoções e saber lidar com elas, mas ainda há muitos professores que não concordam e nem discordam disto. 
Questão 22: A emoção é importante para a aprendizagem.

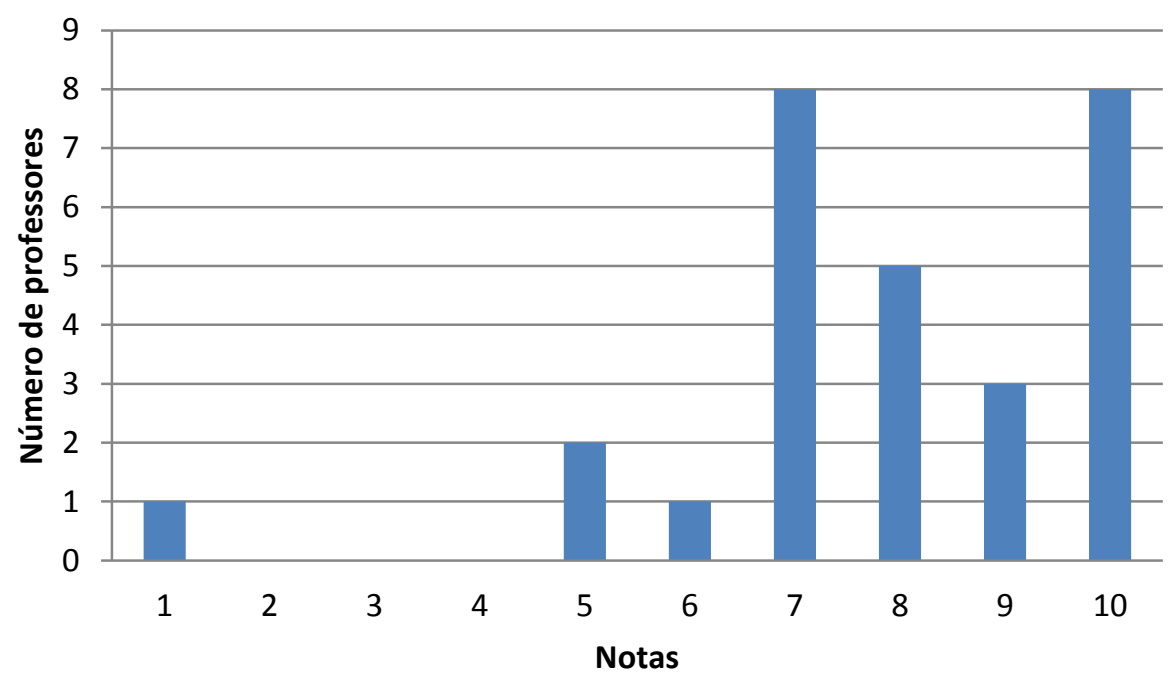

Figura 23: Representação gráfica das respostas dadas pelos professores à questão 22

Questão 23: O aluno que possui uma autoestima desenvolvida tem uma maior capacidade de aprendizagem.

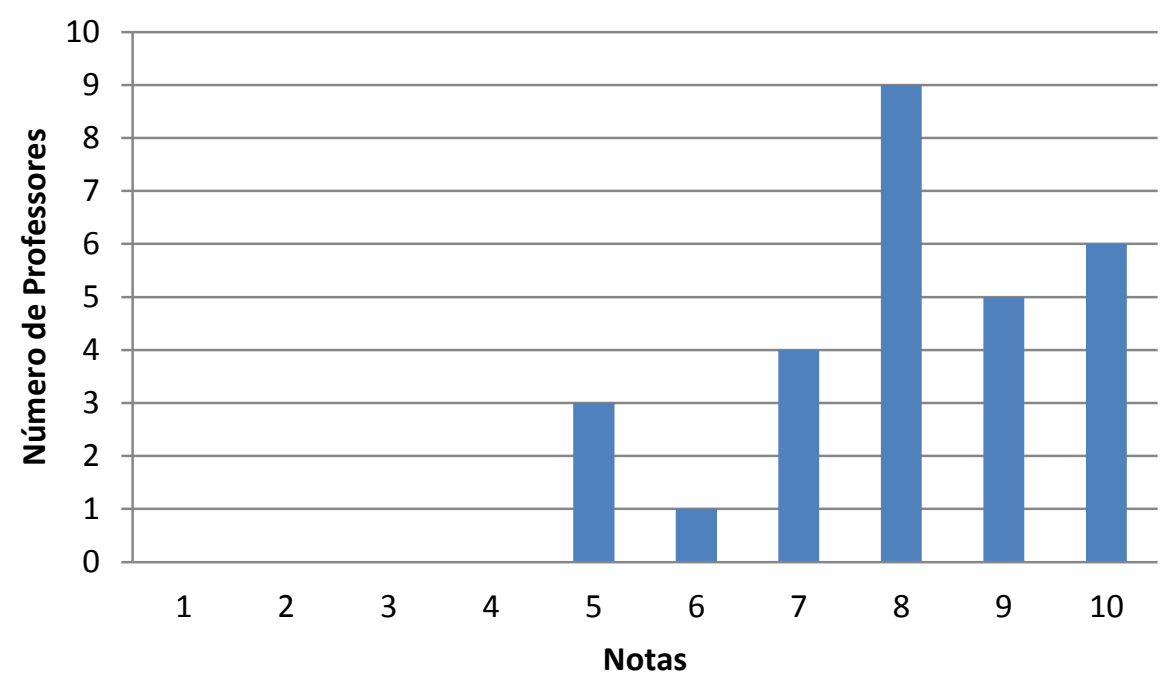

Figura 24: Representação gráfica das respostas dadas pelos professores à questão 23

Nos gráficos contidos nas Figuras 21, 22, 23, 24 e 25 fica evidente que a emoção, apesar de ser importante para a aprendizagem, é um obstáculo na sala de aula, o que nos permite inferir que para estes professores a sala de aula é local onde a razão deve ser o único elemento nas tomadas de decisões. 
Maturana diz "que o ser humano é vivido no conversar, no entrelaçamento do linguajar e do emocionar que é o conversar" (1997, p.121). Não há como separar estes três elementos, emoção, razão e linguagem na vida e muito menos dentro de uma sala de aula, a emoção faz parte da aprendizagem como de nossas tomadas de decisões.

A sala de aula é o espaço onde essas interações acontecem, onde a dinâmica emocional gera conversação, ação humana e a interação educativa.

Questão 26: Um dos papéis do professor é identificar as emoções dos alunos em sala de aula.

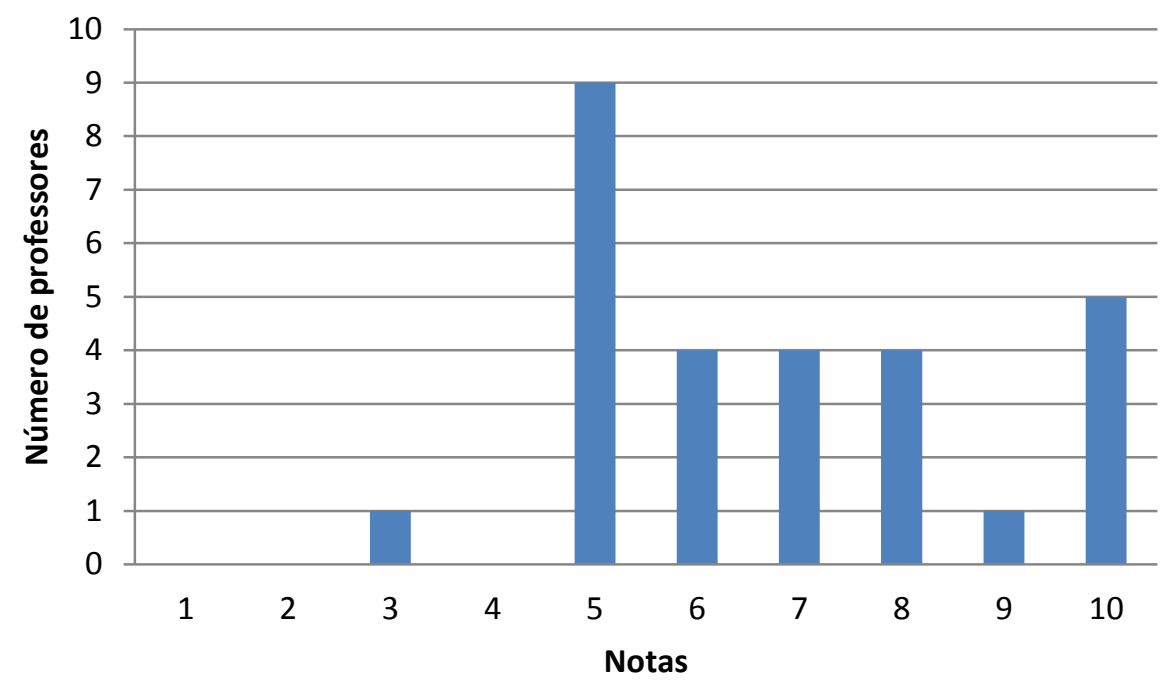

Figura 25: Representação gráfica das respostas dadas pelos professores à questão 26

Podemos verificar que na questão 24 (Figura 26), dezenove professores de ciências concordam com a ideia de que qualquer aluno consegue aprender independentemente de suas relações (emoções) conflitivas em família enquanto quatro professores se mostraram indecisos e cinco não concordaram.

Fica claro neste mesmo gráfico que para o professor a emoção não participa do processo de aprendizagem, pois se o aluno tem uma relação conflitiva na família isso não interfere em sua aprendizagem, como se a razão fosse o único elemento que participasse deste processo. 
Questão 24: O aluno que possui uma relação conflitiva na família pode aprender qualquer assunto.

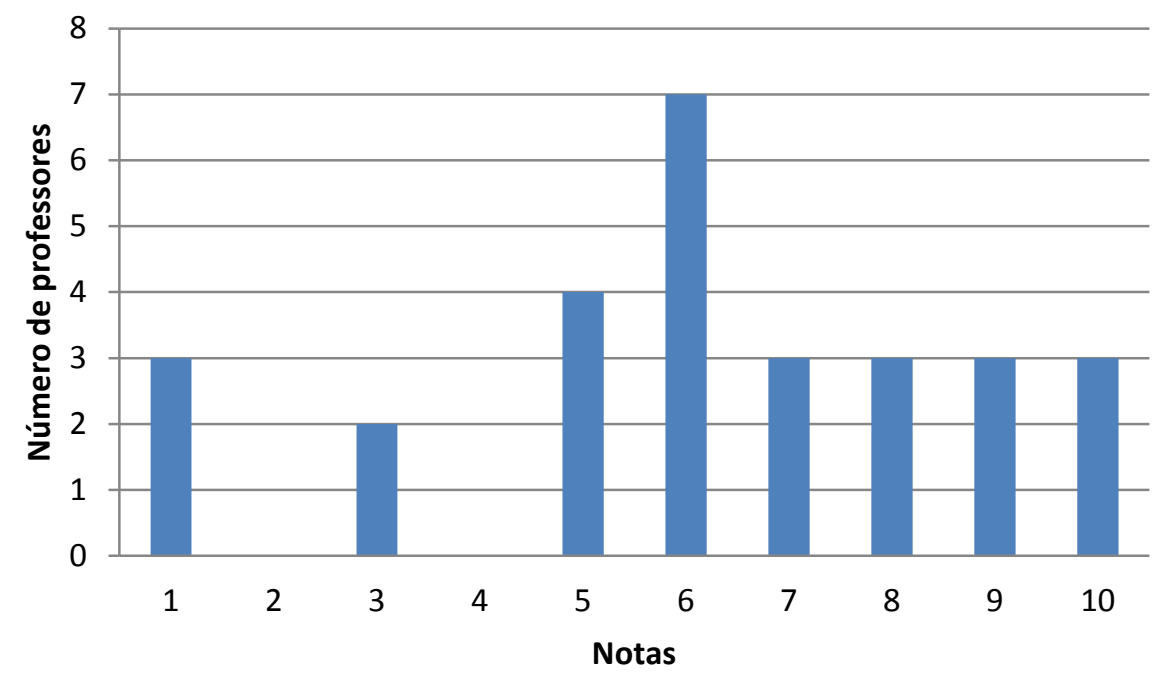

Figura 26: Representação gráfica das respostas dadas pelos professores à questão 24

Questão 25: A emoção fundamental do ser humano é o amor.

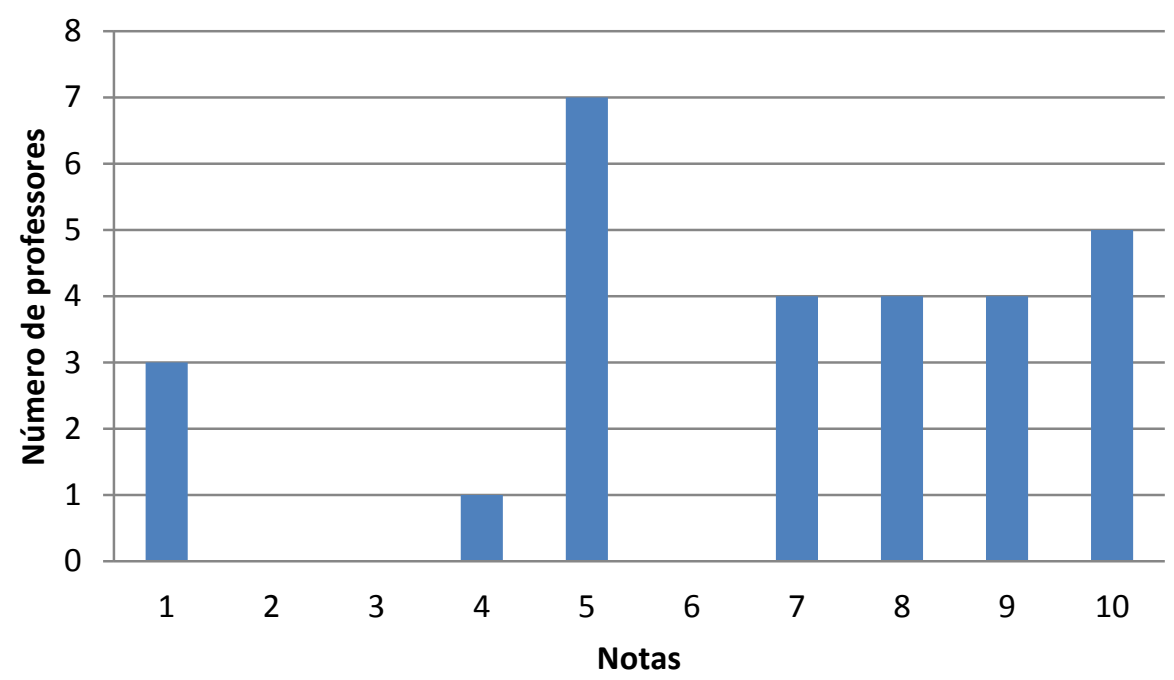

Figura 27: Representação gráfica das respostas dadas pelos professores à questão 25

Muitos professores na questão 25 (Figura 27) concordam com a afirmação que o amor é a emoção que fundamenta o humano, mas percebemos um grupo de sete professores que não concordam e nem discordam de tal afirmação, provavelmente por não entender em que sentido o amor está sendo utilizado na 
frase. Neste mesmo gráfico, quatro professores mostraram não concordar com esta afirmação.

O gráfico da questão 27 (Figura 28) mostra que os professores aceitam a firmação que diz que o amor pode modificar as relações em sala de aula e assim modificar as relações com o conhecimento. Um professor se mostra contra esta afirmação e três destes professores não concordam e nem discordam.

A palavra amor (Figuras 27 e 28 ) tem para alguns professores uma conotação negativa, muito associada à pedagogia do afeto de Gabriel Chalita, onde o afeto é traduzido como "jeito delicado de o professor corrigir o aprendiz, na forma serena de explicar, de transmitir informações de tirar dúvidas" (grifo nosso, trecho retirado de uma entrevista no site www.gabrielchalita.com.br).

Questão 27: $O$ amor pode modificar a relação triádica professor/aluno/ conhecimento.

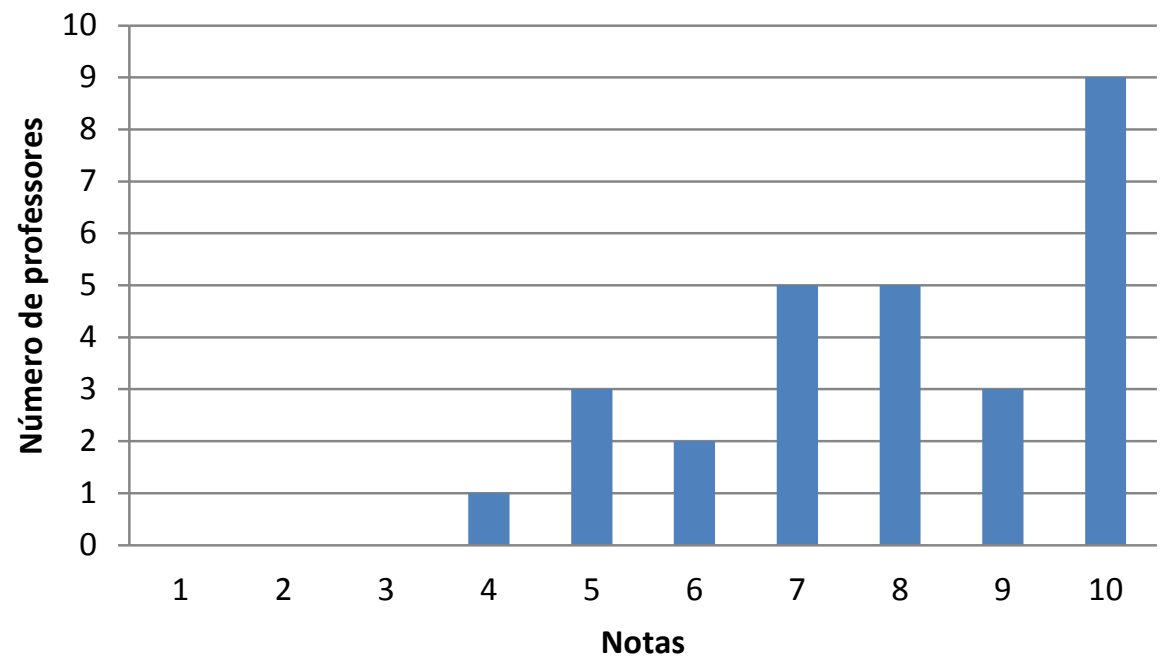

Figura 28: Representação gráfica das respostas dadas pelos professores à questão 27

Para Maturana a emoção que está na base da humanidade, do social e de nossas reflexões éticas é o amor, ele é o fundamento do fenômeno social e não o contrário.

O amor é a emoção necessária para que se abra espaço para as interações sociais e é através dele que enxergamos o outro como legítimo outro, na convivência, no respeito e na confiança, sem ele não há humanidade. 
Alguns professores concordam que os alunos não se manifestam em sala de aula mesmo quando abrimos espaço para eles, enquanto dez professores discordam desta afirmação e nove professores não concordam totalmente e nem discordam.

Questão 28: Quando abrimos espaço para discussão em sala de aula normalmente os alunos não se manifestam.

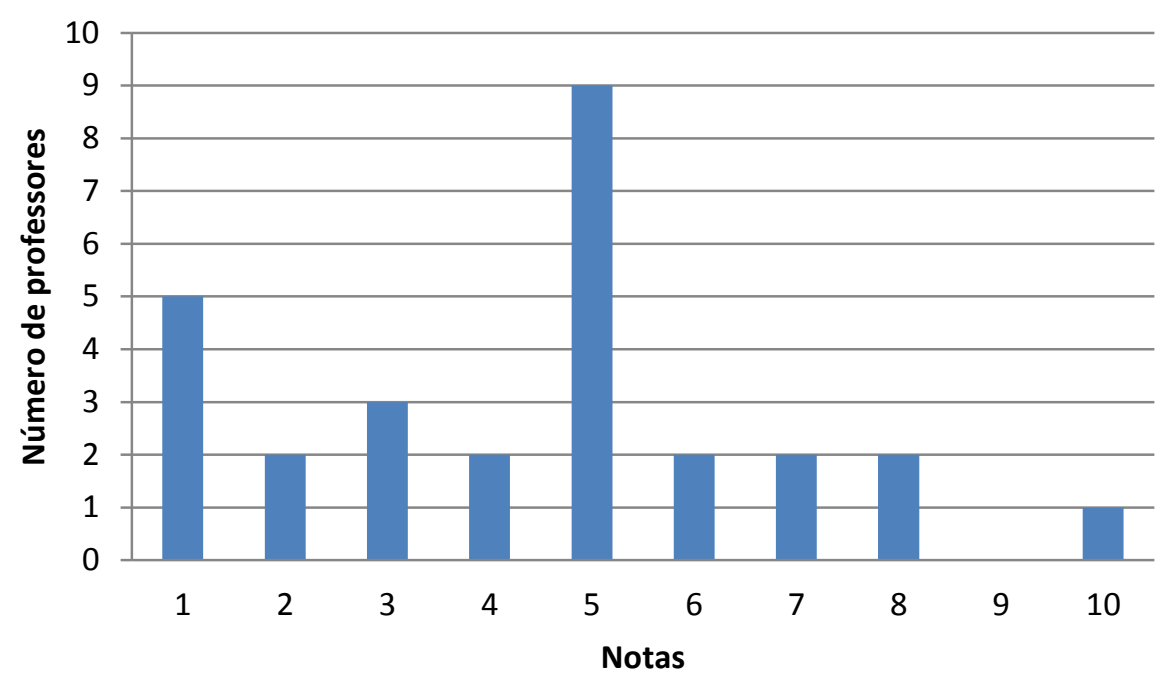

Figura 29: Representação gráfica das respostas dadas pelos professores à questão 28

Questão 29: É preciso abrir espaços para discussões em sala de aula.

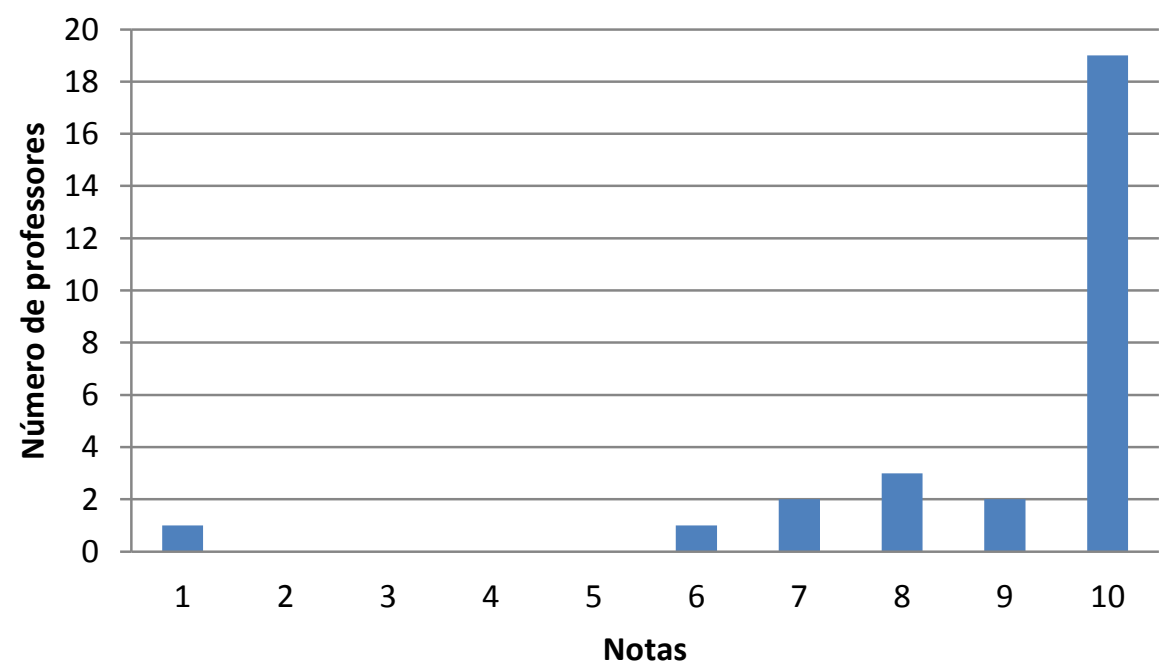

Figura 30: Representação gráfica das respostas dadas pelos professores à questão 29 
Neste gráfico 30 fica claro que a grande maioria de professores concorda que é necessário abrir espaços para que os alunos se manifestem e apenas um professor desta amostragem discorda desta afirmação.

Questão 30: Normalmente os alunos não se manifestam nas discussões em aula por que não abrimos espaço para eles.

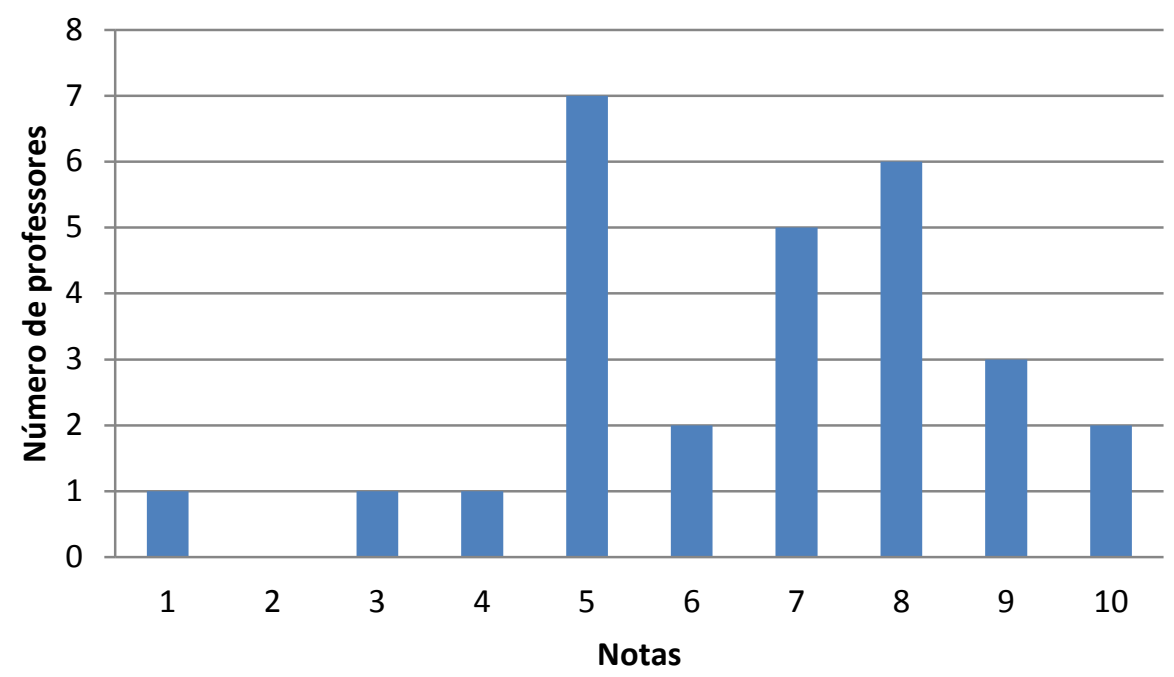

Figura 31: Representação gráfica das respostas dadas pelos professores à questão 30

O gráfico da questão 30 (Figura 31) expõe claramente que apesar dos professores acreditarem que é necessário abrir espaço para o aluno se manifestar em sala de aula, muitos deles em torno de dezoito professores concordam que os alunos não se manifestam porque não abrimos espaço.

Nos gráficos apresentados nas Figuras 29, 30 e 31 observamos uma contradição das respostas, pois os professores afirmam que precisamos abrir espaço para os alunos em sala de aula, mas também assumem que os alunos não se manifestam porque não abrimos espaço. Abrir espaço para que os alunos se manifestem sem medo em sala de aula é ação necessária que o professor em alguns casos não o faz.

Muitos professores discordam da afirmação, mas há um grupo de seis professores que concordam que os alunos não têm conhecimentos prévios sobre os assuntos abordados e seis professores estão indecisos entre concordar e discordar. 
Questão 31: Os alunos não possuem conhecimento prévio sobre os assuntos abordados.

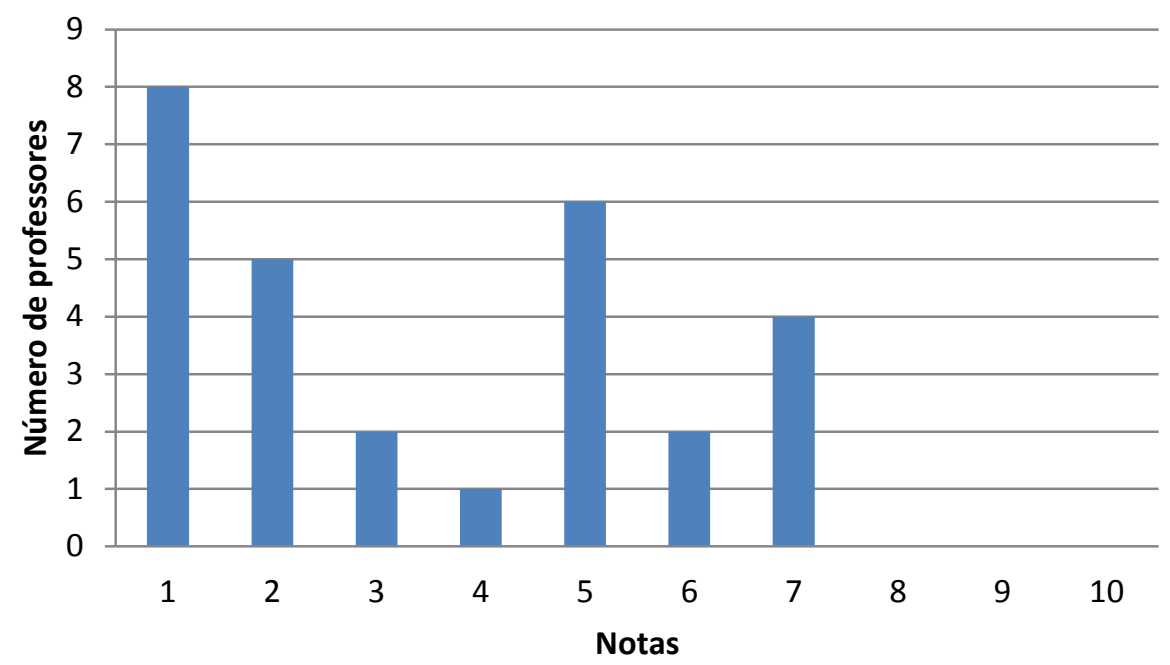

Figura 32: Representação gráfica das respostas dadas pelos professores à questão 31

Questão 32: A aprendizagem pode ser provocada através das intervenções do professor.

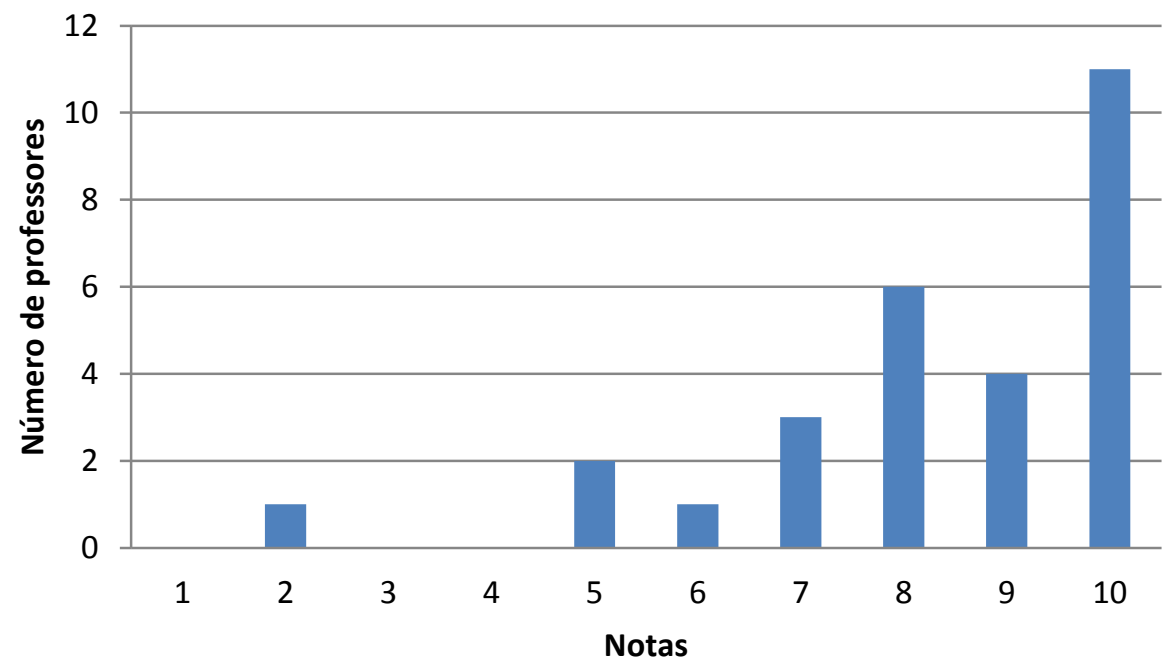

Figura 33: Representação gráfica das respostas dadas pelos professores à questão 32

A partir do gráfico apresentado na Figura 32 podemos inferir que alguns professores não consideram as concepções cotidianas de seus alunos como sendo conhecimento prévio. 
A análise do gráfico da questão 32 (Figura 33) explicita que a grande maioria destes professores de nossa amostra concorda que a aprendizagem pode ser provocada pela intervenção do professor, enquanto um professor discorda desta afirmação e dois professores se mostram indecisos quanto a concordam ou não com ela.

Questão 35: A educação é um processo no qual alunos e professores se transformam enquanto interagem.

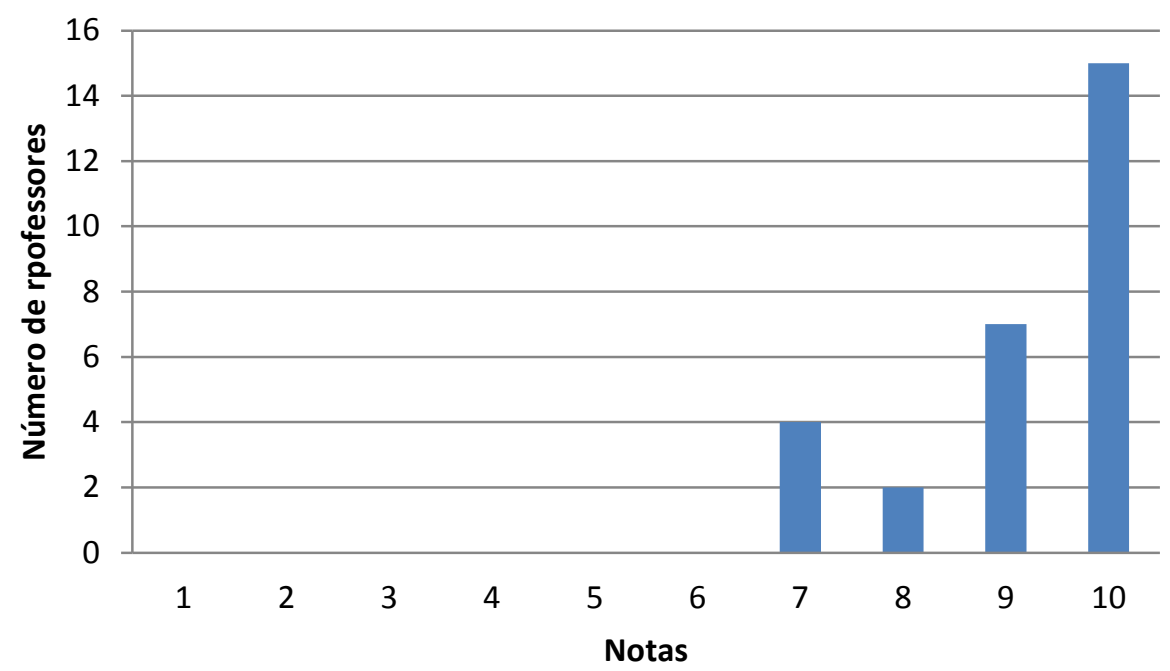

Figura 34: Representação gráfica das respostas dadas pelos professores à questão 35

Neste gráfico 34 podemos observar que os professores que responderam ao questionário possuem a ideia de transformação entre professores e alunos através da interação.

Os gráficos apresentados nas Figuras 33 e 34 indicam que os professores aceitam ou acreditam que há transformações enquanto interagem com seus alunos, mas uma parcela desses professores possuem dúvidas que essas interações possam provocar aprendizagem.

Neste gráfico 35 os professores em sua maioria aceitam que linguagem e a cognição se constituem socialmente e apenas três professores ficaram indecisos quanto a esta afirmação. 
Questão 34: A linguagem e a cognição estão constantemente se constituindo socialmente.

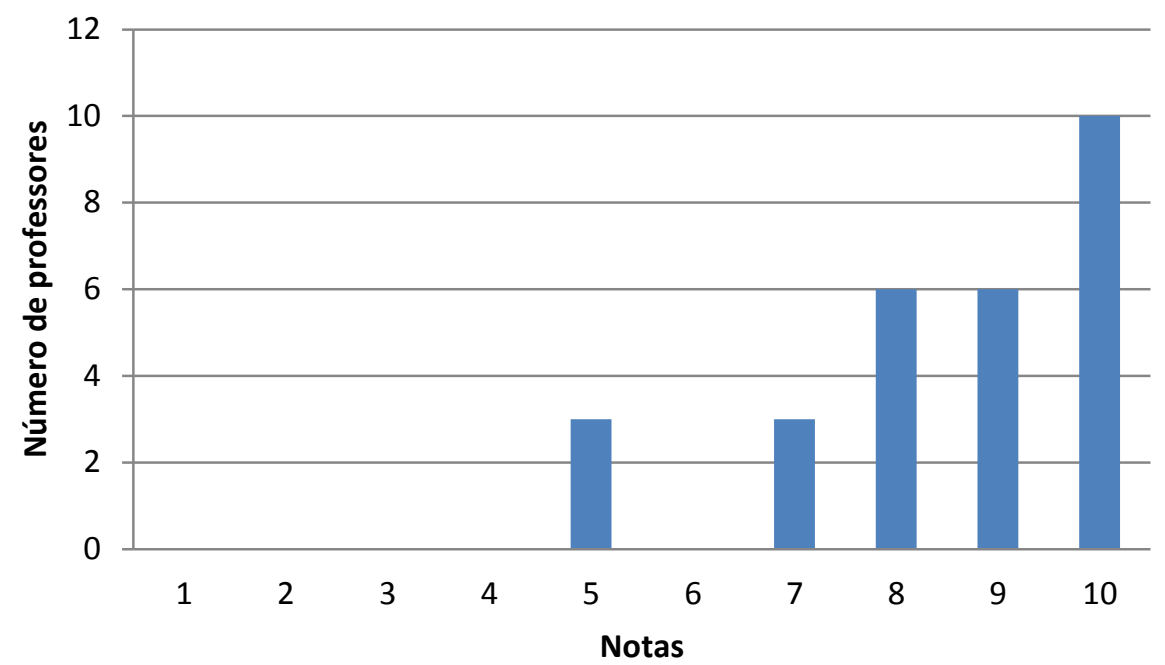

Figura 35: Representação gráfica das respostas dadas pelos professores à questão 34

Questão 36: O ser humano se constitui na linguagem.

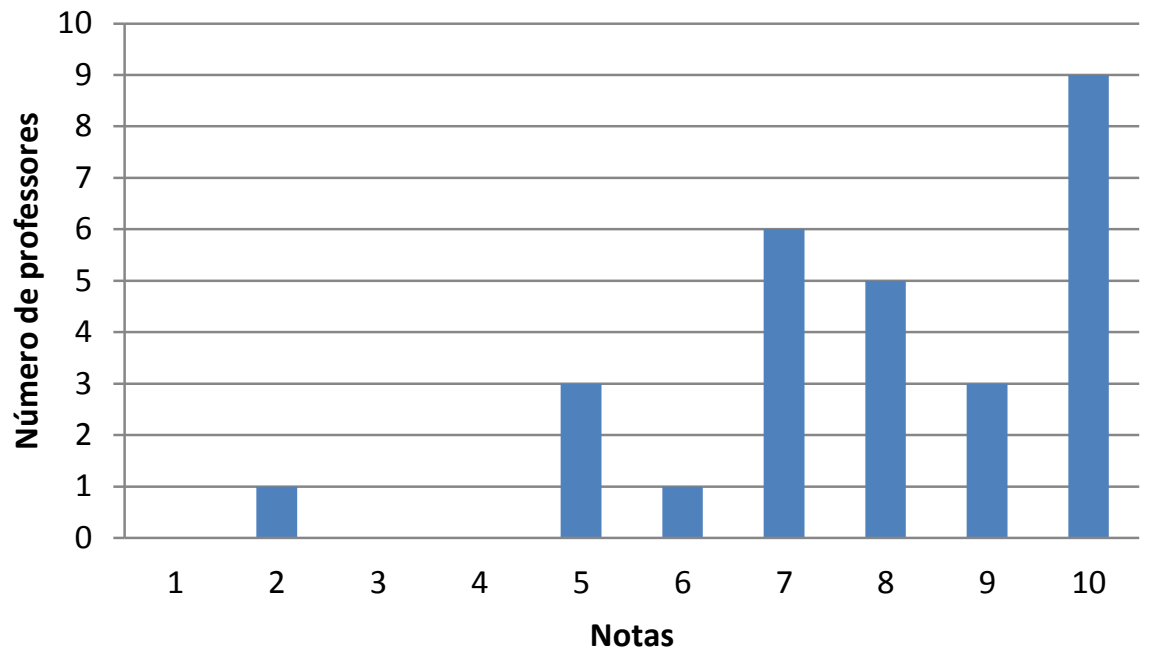

Figura 36: Representação gráfica das respostas dadas pelos professores à questão 36

$\mathrm{Na}$ questão 36 (Figura 36) a grande maioria dos professores demonstra concordar que a linguagem é fator fundamental na constituição do ser humano, mas podemos observar também que há professores indecisos quanto a esta afirmação e um professor manifestou sua discordância quase que total em relação a ela. 
Nos gráficos apresentados nas Figuras 35 e 36 parece haver algumas dúvidas a respeito do valor da linguagem para o processo educativo. Maturana propõe que para ocorrer mudança de estado do indivíduo é necessário uma mudança estrutural que permitirá surgir uma conduta adequada (aprendizagem). Essa mudança estrutural ocorre nas interações entre professores e alunos através da linguagem, onde o amor está presente permitindo que o outro seja visto como legítimo outro em um ambiente de confiança mútua.

$\mathrm{Na}$ questão 37 (Figura 37 ) praticamente metade dos professores que responderam ao questionário concordam que a escola é um espaço de ampliação da inteligência, outros sete professores mostraram não concordar e nem discordar totalmente e três discordaram da afirmação.

Questão 37: O espaço educacional é um espaço de ampliação da inteligência.

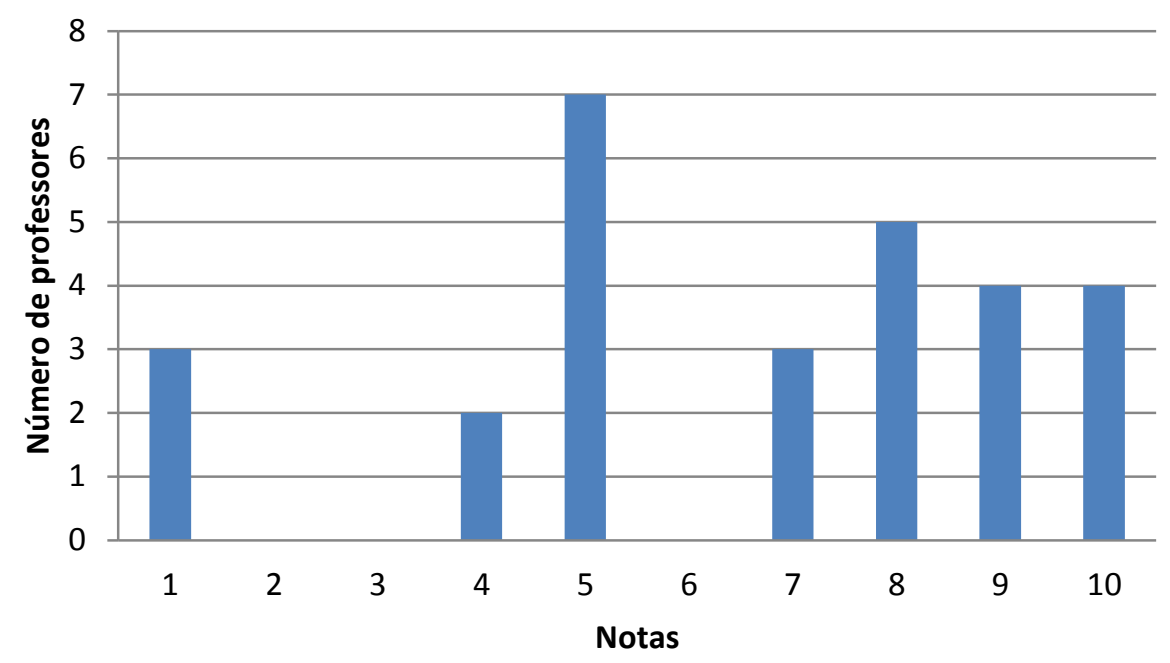

Figura 37: Representação gráfica das respostas dadas pelos professores à questão 37

Quando utilizamos a ideia de avaliação sobre o fazer do aluno e não sobre o seu ser percebemos uma dispersão nos dados, que se mostraram mais espalhados no gráfico 38 , apesar de mais da metade dos professores concordarem com a frase.

Os gráficos apresentados nas Figuras 37 e 38 mostram as divergências de opiniões a respeito da escola como local de ampliação da inteligência e as opiniões ficam mais heterogêneas quando se trata de avaliação. 
Questão 38: A avaliação deve ser feita sobre o fazer do estudante e não sobre seu ser.

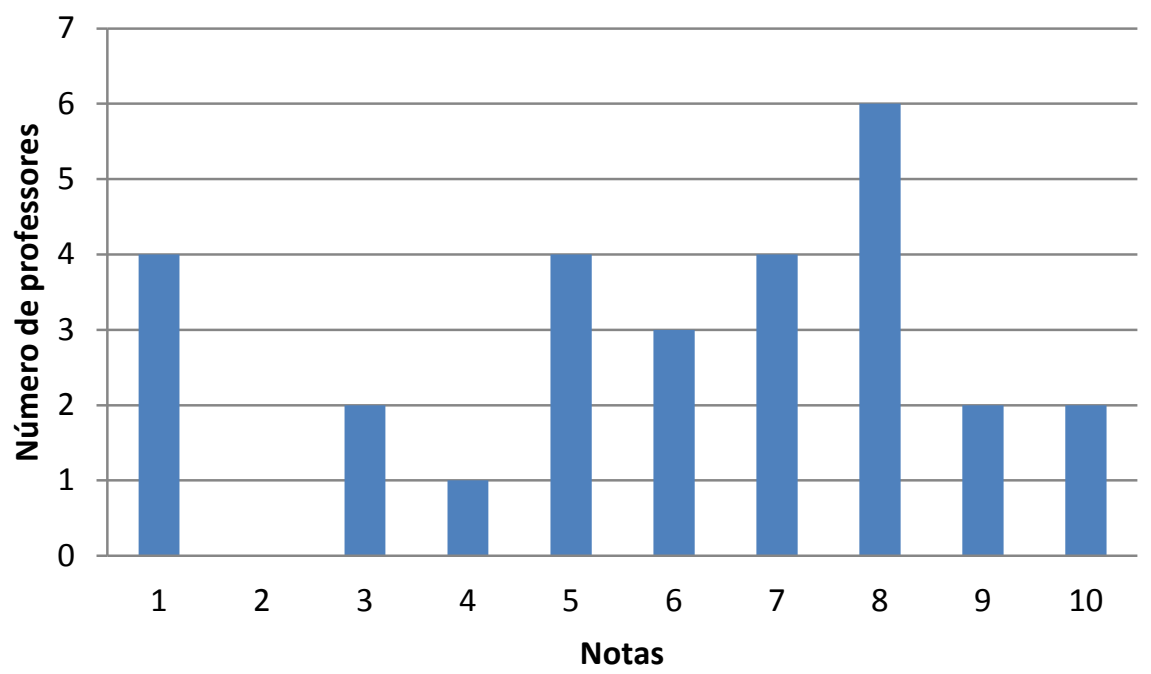

Figura 38: Representação gráfica das respostas dadas pelos professores à questão 38

Segundo Maturana (1997, p.22) a inteligência está associada à emoção, para ele as emoções como competição e inveja reduzem a inteligência e "para que $o$ espaço educacional seja um espaço de ampliação de inteligência e criatividade não pode haver avaliações do ser do estudante, só do seu fazer".

Durante o processo de qualificação foram sugeridas pequenas mudanças no questionário e no modo de aplicação. Com a intenção de identificar o quanto as concepções dos professores se aproximavam ou não das ideias de Maturana. $O$ questionário de 38 questões foi transformado em um opiniário de 15 afirmações (Apêndice 5) adaptadas das obras de Maturana.

As frases foram analisadas por um grupo de apoio, formado por mestrandos em ensino de ciências e professores orientadores, e aquelas afirmações que se mostraram com um vocabulário muito específico de Maturana e que não foram de fácil compreensão foram modificadas e simplificadas com o cuidado para que não perdessem o seu principal sentido.

Paralelamente à preparação das frases do opiniário, foram realizadas várias reuniões com colaboradores que nos ajudaram a chegar a uma escala final. As recomendações da Prof. a Dra. Ana Amélia Benedito da Silva, da EACH indicaram a utilização de uma escala gráfica onde o professor poderia escolher um local, não 
específico e nem graduado, em uma escala situada em uma reta que iria entre concordo e não concordo. Esta escala foi utilizada com o grupo de apoio e foi possível notar um incômodo geral com a falta de uma escala visível de números.

Uma nova escala foi elaborada com a colaboração da Prof. ${ }^{a}$ Dra. Nilda Montes Villanueva, da Universidade Federal de Lima, que sugeriu manter a escala do tipo Likert (Apêndice 5), mas com maiores possibilidades de graduar a concordância ou não com a frase. Neste novo opiniário o professor tinha a possibilidade de se manifestar em relação às afirmações, pois em cada um delas poderia após uma reflexão, escrever observações, críticas, sugestões e insatisfações, comentários que foram de extremo valor para a análise e discussão do trabalho.

Depois de passar mais uma vez pelo grupo de apoio, o opiniário foi aplicado, no formato virtual e também presencial, a 46 professores (Apêndice 7) de Biologia, Química, Física e Matemática da rede pública e particular, a maioria da cidade de São Paulo, que aceitaram participar desta pesquisa assinando um termo de consentimento livre e esclarecido (Apêndice10).

As respostas a cada afirmação do opiniário foram tabuladas (Apêndice 6) e analisadas através da analise de variância (ANOVA) para verificar diferenças significativas $(p \leq 0,05)$ em relação ao sexo, faixa etária, disciplina e tempo de serviço dos entrevistados no que se refere ao seu grau de concordância ou discordância das afirmações colocadas no estudo. Quando houve significância estatística no teste $F$ da ANOVA, foi realizada uma analise posterior através de testes de Tukey $(p \leq 0,05)$ para comparações pareadas de médias. As questões 3 e 4 respondidas por alguns professores foram transcritas (Apêndices 8 e 9) integralmente em nosso trabalho de acordo como foram registradas nos opiniários. Foi feita uma análise qualitativa destas respostas, comparando-as com as concepções epistemológicas de Maturana. A análise dos textos foi feita a princípio levando-se em consideração as três categorias teóricas, posteriormente com a leitura dos textos, surgiram algumas categorias empíricas que serão mostradas mais adiante.

Nas obras de Maturana o valor da razão, emoção e linguagem para a constituição do indivíduo e do seu conhecer é explicito, desta maneira, escolhemos estes três conceitos como categorias teóricas, que procuramos identificar nas 
respostas dadas pelos professores ao opiniário. Para o autor não podemos separar razão, emoção e linguagem, pois estão intrinsecamente relacionadas. O que faremos então será um ato de distinção no qual separamos o designado, distinguindo de um fundo, ou seja, olharemos com mais destaque suas propriedades. Nas palavras do autor:

[...] Cada vez que fazemos referência a algo, implícita ou explicitamente, estamos especificando um critério de distinção que assinala aquilo de que falamos e especifica suas propriedades como ente, unidade ou objeto [...] (Maturana, 2001, p.47)

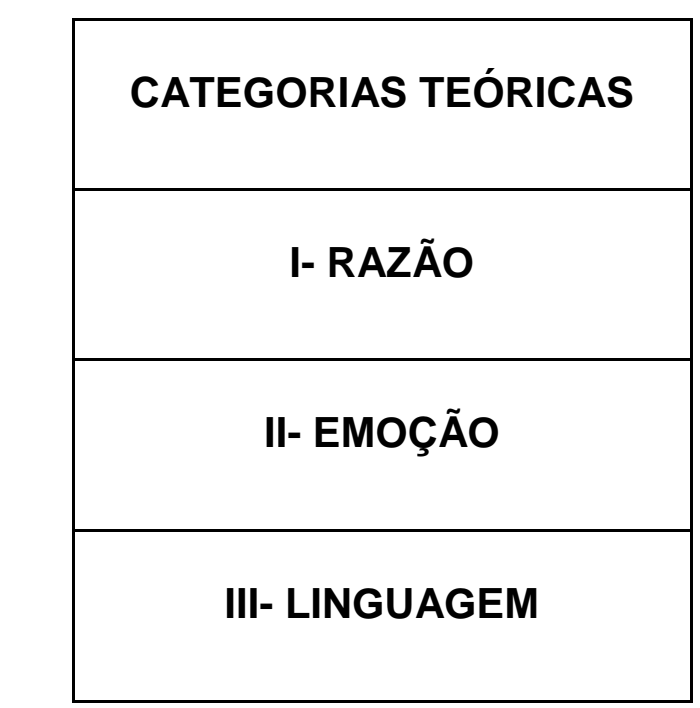

Tabela 1. Categorias teóricas elaboradas à partir das obras de Maturana 


\section{Análise de Resultados e Discussão}

\subsection{Análise das respostas para a escala Likert do opiniário}

A análise quantitativa dos dados obtidos nos permitiu vislumbrar um panorama mais abrangente das ideias da nossa amostra de professores e com ela pudemos observar que na maioria das afirmações não houve diferenças significativas ( $p>0.05$ ) em relação ao sexo, faixa etária, disciplina e nem tempo de serviço no grau de concordância/discordância das afirmações dos entrevistados. Todas as tabelas e gráficos produzidos durante essa etapa estão reunidos no Anexo1.

A seguir discutiremos brevemente as afirmações nas quais não houve diferenças significativas entre as pontuações atribuídas pelos professores.

Para a afirmação 1 (Gráfico 39): "As diferentes emoções, tanto positivas quanto negativas, regulam a linguagem dentro de sala de aula o que favorece a manifestação de condutas diferentes.", a média obtida a partir das respostas dos professores foi de 7.7, o que significa que em geral, os professores concordaram muito com esta afirmação. Este resultado já era esperado, pois acreditamos que os professores em geral sabem a importância da emoção para a manifestação de condutas em sala de aula e o quanto essas emoções permeiam a nossa linguagem. Um ambiente onde emoções positivas como a confiança, o respeito e a valorização estejam presentes será mais favorável ao surgimento de condutas mais positivas e a uma relação ensino/aprendizagem mais eficaz, no sentido em que esta seja mais significativa para o aluno e para o professor.

Para a afirmação 2 (Gráfico 40): "As emoções definem nossa racionalidade, ou seja, como pensamos", a média foi de 6.5 , o que significa que os professores em sua maioria atribuíram notas que variaram entre concordo ligeiramente a concordo moderadamente. Ainda encontramos nestes professores, em particular, uma dificuldade em aceitar a emoção como norteadora de nossas ações, pensamentos e, portanto, de nossa racionalidade. A ideia de professor racional, detentor do conhecimento, principalmente nos professores de ciências, é muito enraizada. 


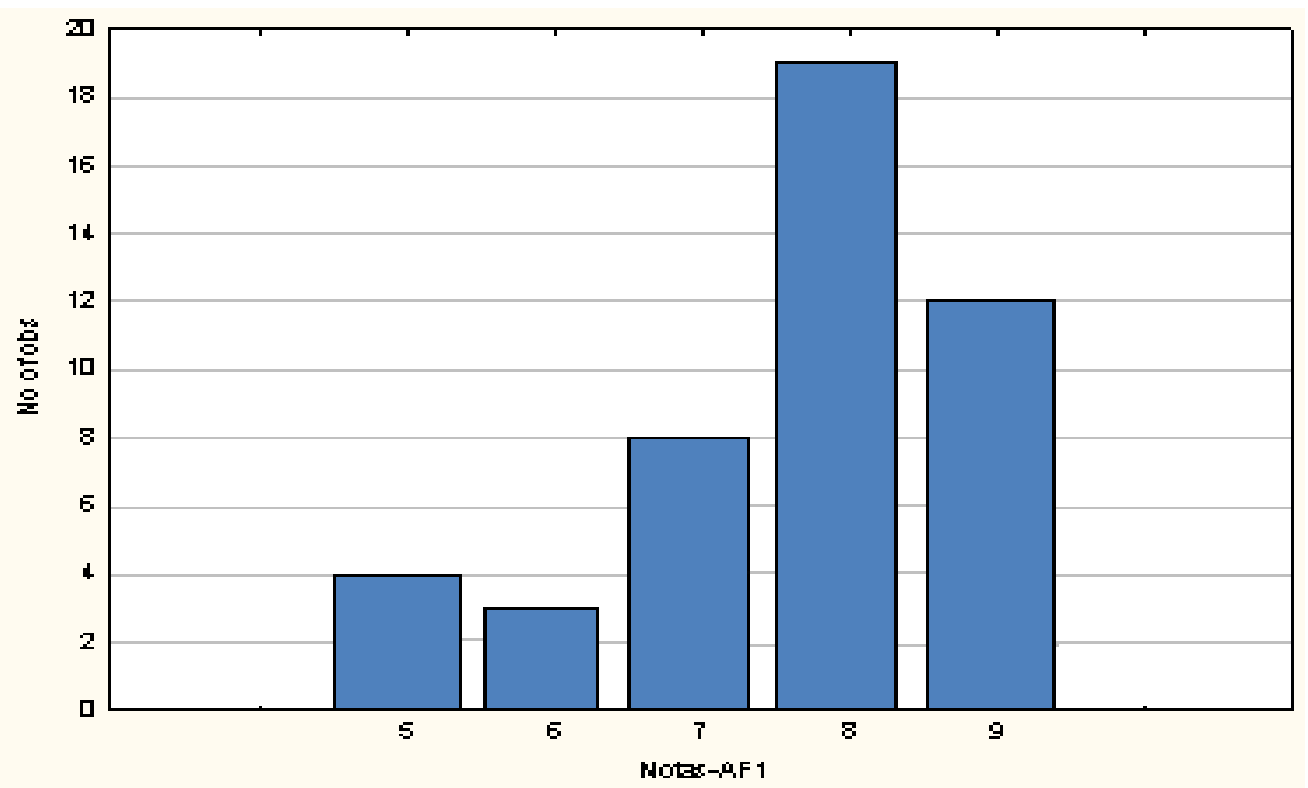

Figura 39: Gráfico que indica as notas atribuídas pelos professores à afirmação 1.

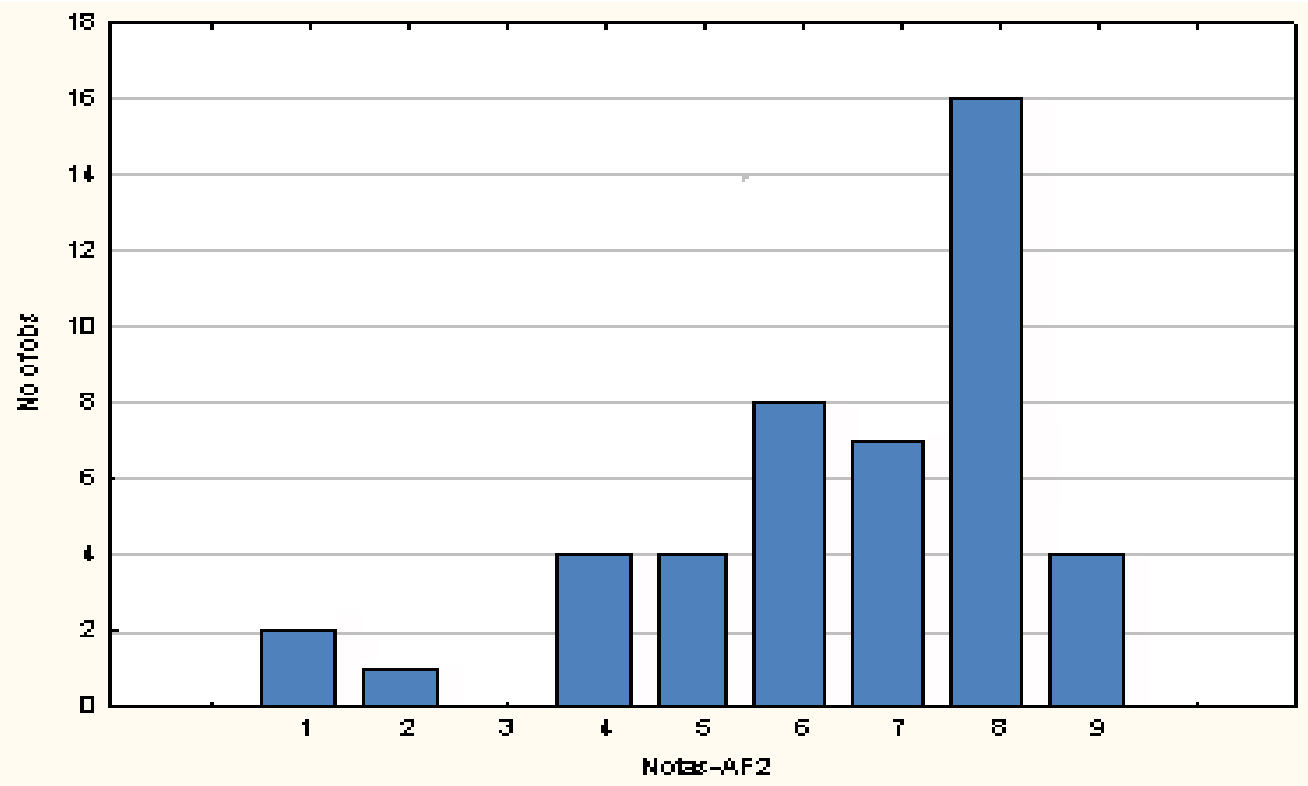

Figura 40: Gráfico que indica as notas atribuídas pelos professores à afirmação 2.

Para a afirmação 3 (Gráfico 41): "Professores e alunos interagem permanentemente uns com os outros de modo espontâneo e recíproco", a média obtida foi em torno de 6.0, o que significa que os professores concordaram ligeiramente com esta afirmação. Percebemos, ao aplicar o opiniário, que quando expressamos que a convivência entre alunos e professores ocorre de maneira 
espontânea e recíproca alguns professores tiveram dificuldades em aceitar a frase e se incomodaram com a palavra espontânea e podemos observar essas dificuldades verificando a dispersão nas respostas dadas à afirmação

O professor 30 afirmou: "quando estamos em sala de aula não somos espontâneos, pois temos a aula toda planejada, o que vamos dizer e como vamos agir". Quando interagimos em sala de aula, levados pela emoção, essa interação sempre será espontânea e recíproca, gerando desta forma emoções positivas ou negativas. Em uma sala de aula onde o professor ignora ou até menospreza as ideias do aluno ou onde o aluno desrespeita o professor, a reciprocidade de emoções negativas, que podem gerar ações negativas, será um fato. Da mesma maneira, quando em sala de aula o respeito e a confiança fazem parte do dia a dia, o fluir das ações será espontaneamente harmoniosa.

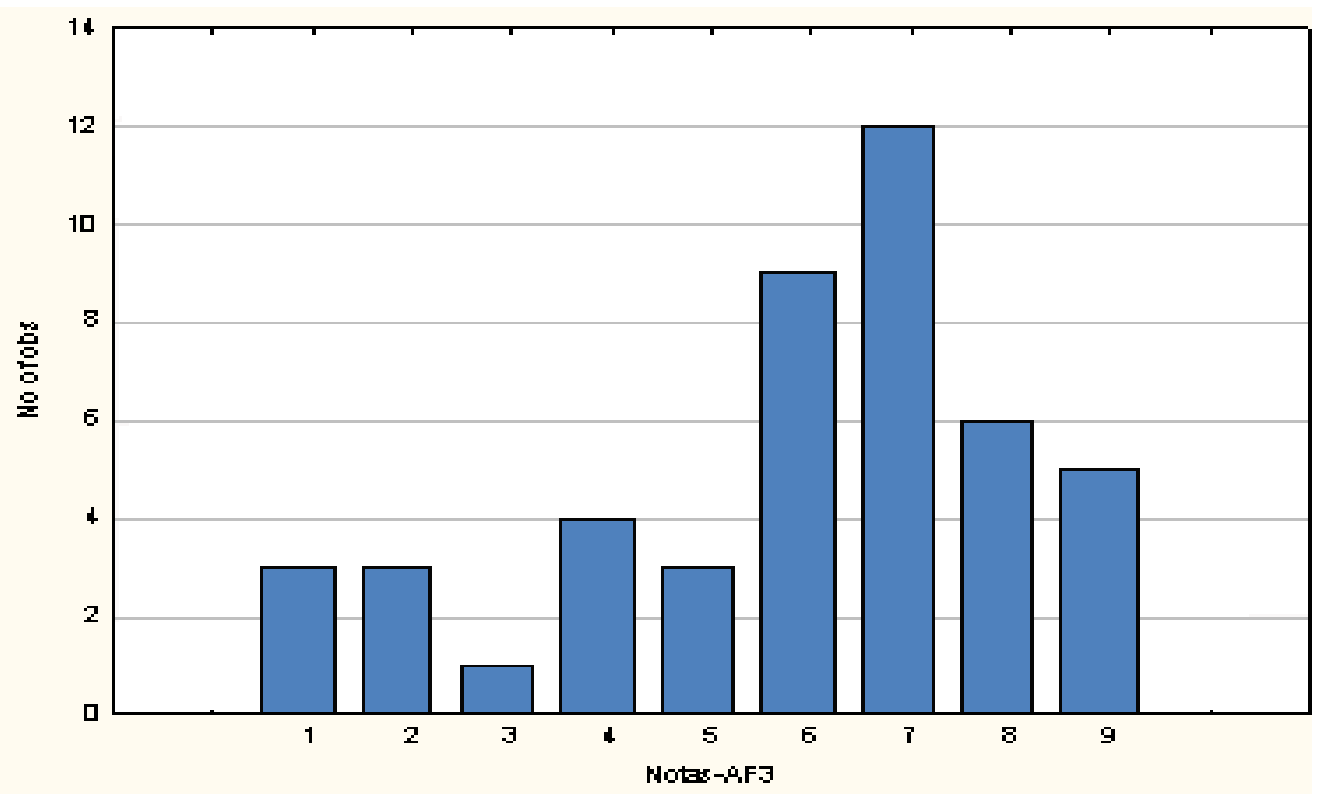

Figura 41: Gráfico que indica as notas atribuídas pelos professores à afirmação 3.

Para a afirmação 4 (Gráfico 42): “O amor é a condição espontânea para a aceitação do outro como legítimo outro, para a convivência em uma sala de aula", se obteve uma média em torno de 6.0, o que significa que os professores concordaram ligeiramente com esta afirmação. Nos gráfico referente a esta questão podemos perceber que há divergências entre as respostas, pois alguns professores não concordaram com a afirmação. Nos ensaios de pré-teste feitos com a finalidade de 
aprimorar e selecionar as afirmações definitivas e no opiniário final, em todo momento em que o amor foi citado, como necessário em uma sala de aula para a interação professor/aluno, houve discordância e parecia que alguns professores ficavam incomodados. O amor para Maturana, o que acreditamos também, é condição dinâmica espontânea de aceitação, uma emoção que permite enxergar o outro como legítimo outro e com isso abrimos espaços para que esse outro se manifeste. Em uma sala de aula isso é essencial. $O$ amor não é visto como um fenômeno biológico, para a maioria dos professores entrevistados ele é poderoso. Como veremos adiante em alguns trechos de textos escritos por professores. Observamos no gráfico a seguir a grande dispersão de respostas dadas a esta afirmação, demonstrando a dificuldade de interpretar ou aceitar a afirmação.

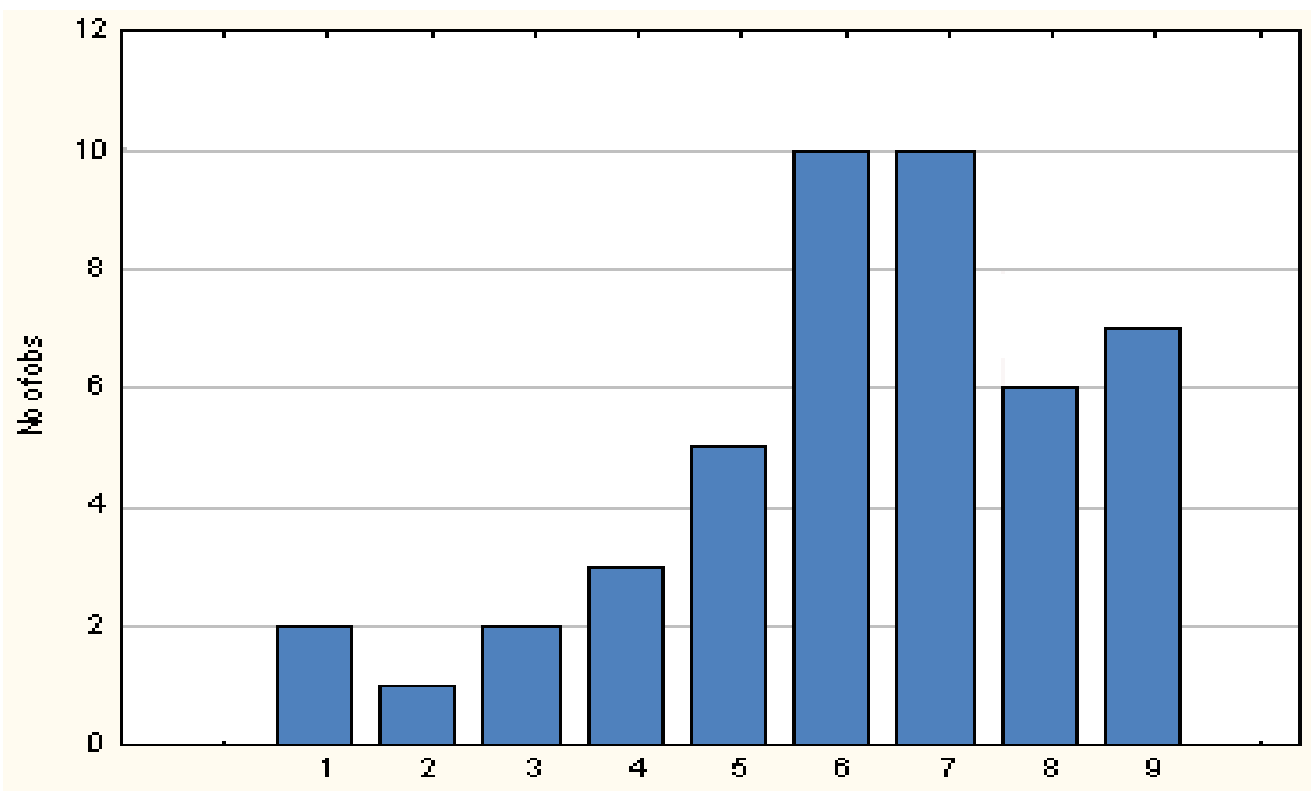

Figura 42: Gráfico que indica as notas atribuídas pelos professores à afirmação 4.

Para a afirmação 5 (Gráfico 43): "O amor é o fundamento do social, porque ao permitir a coexistência do outro conosco, permite a nossa socialização através da linguagem. Portanto, é o amor que permitiu nossa história evolutiva", se obteve uma média em torno de 6.0, o que significa que os professores concordaram ligeiramente com estas afirmações. Interpretamos essa média de concordância assim como a distribuição das respostas no gráfico, como uma dificuldade em compreender o amor como um fenômeno biológico capaz de gerar mudanças e adaptações. 
Aceitamos o respeito e a compaixão associados ao social, mas o amor é considerado muito especial para fazer parte do dia a dia, principalmente na escola. Aprendemos desde muito cedo que o que permitiu a evolução dos seres vivos foi a competição, portanto a ideia revolucionária do amor como motivador e gerador dessa evolução causa rejeição aos professores que aceitaram participar desta pesquisa. Para Maturana o que permitiu a evolução foi a capacidade de colaborar uns com os outros, como seres coletores capazes de trabalhar em grupo. O autor considera sociais as relações que são fundadas na aceitação do outro e para se aceitar o outro como legítimo outro é necessário o amor, portanto, para Maturana, nem todas as relações são sociais.

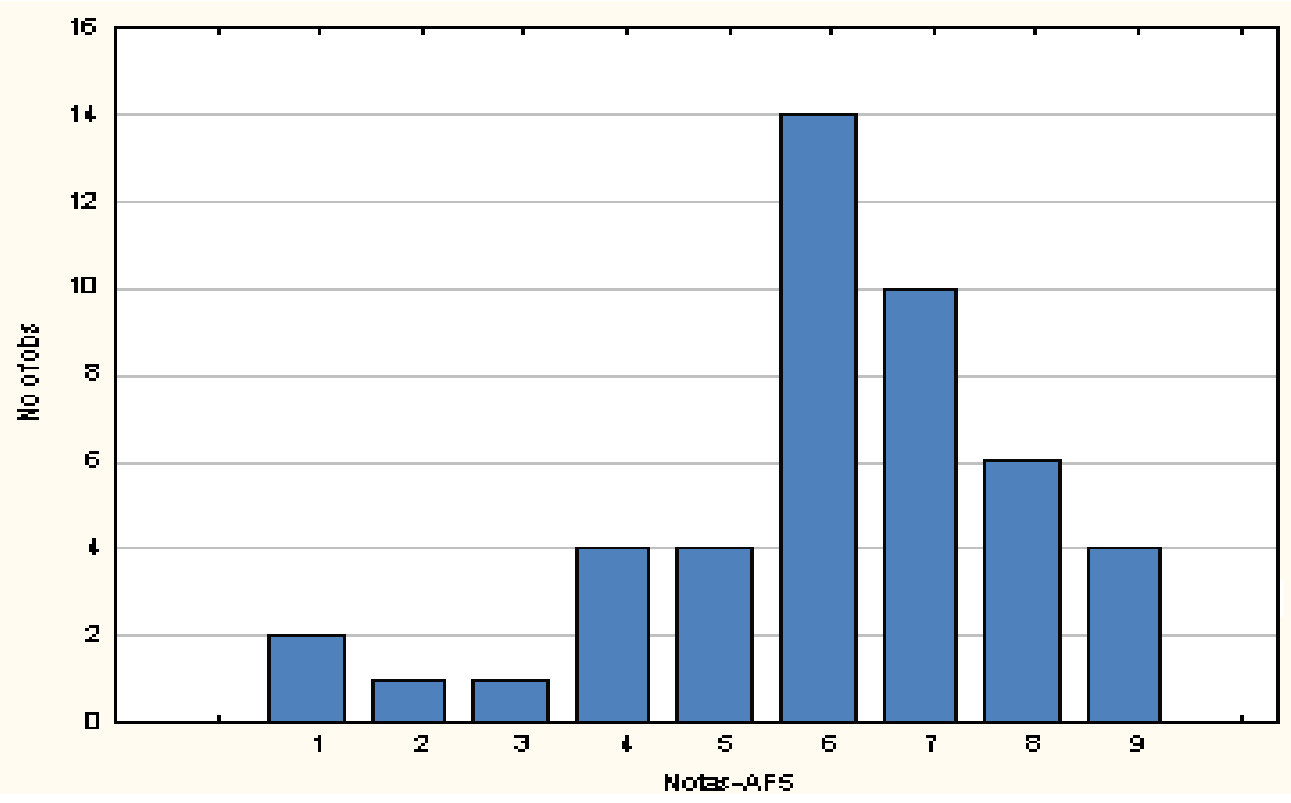

Figura 43: Gráfico que indica as notas atribuídas pelos professores à afirmação 5 .

Para a afirmação 6 (Gráfico 44): "É possível conscientemente através da linguagem e da razão identificar e mudar as nossas emoções em qualquer contexto, escolar ou não.", se obteve uma média de 6.7, o que significa que em geral, os professores concordaram moderadamente com esta afirmação, apesar de quatro professores não concordarem com esta afirmação. Precisamos lembrar que para Maturana a razão, a linguagem e a emoção estão intimamente relacionadas e ao identificarmos as emoções que surgem em qualquer contexto podemos conscientemente transformá-las. 
Esta ideia de mudança nos parece favorável dentro de uma sala de aula, pois convivemos com vários indivíduos, únicos em seu modo de ser e de se relacionar, e as emoções fluem em todas as direções. Estar atento a estas emoções e conscientemente tentar realinhá-las de maneira a favorecer as interações e possíveis aprendizagens é fundamental para a prática pedagógica do professor.

Para a afirmação 8 (Figura 44): "A linguagem nos auxilia na contemplação e na reflexão sobre o mundo em que vivemos", se obteve uma média de 8.4, o que significa que em geral, os professores concordaram muito. Cabe destacar que esta afirmação obteve a maior nota média entre todas as 15 afirmações do opiniário, ou seja, o maior grau de concordância dos professores.

Podemos dizer que esses resultados fugiram do esperado. Considerar a linguagem como um auxílio à reflexão sobre o mundo, apesar de concordarmos com a frase, não esperávamos essa concordância por parte da maioria dos professores, pois a razão se mostra tão mais expressiva na fala de nossos professores que a nossa hipótese nesta afirmação era que os professores não considerariam a linguagem e sim a razão capaz de nos auxiliar na contemplação e compreensão do mundo.

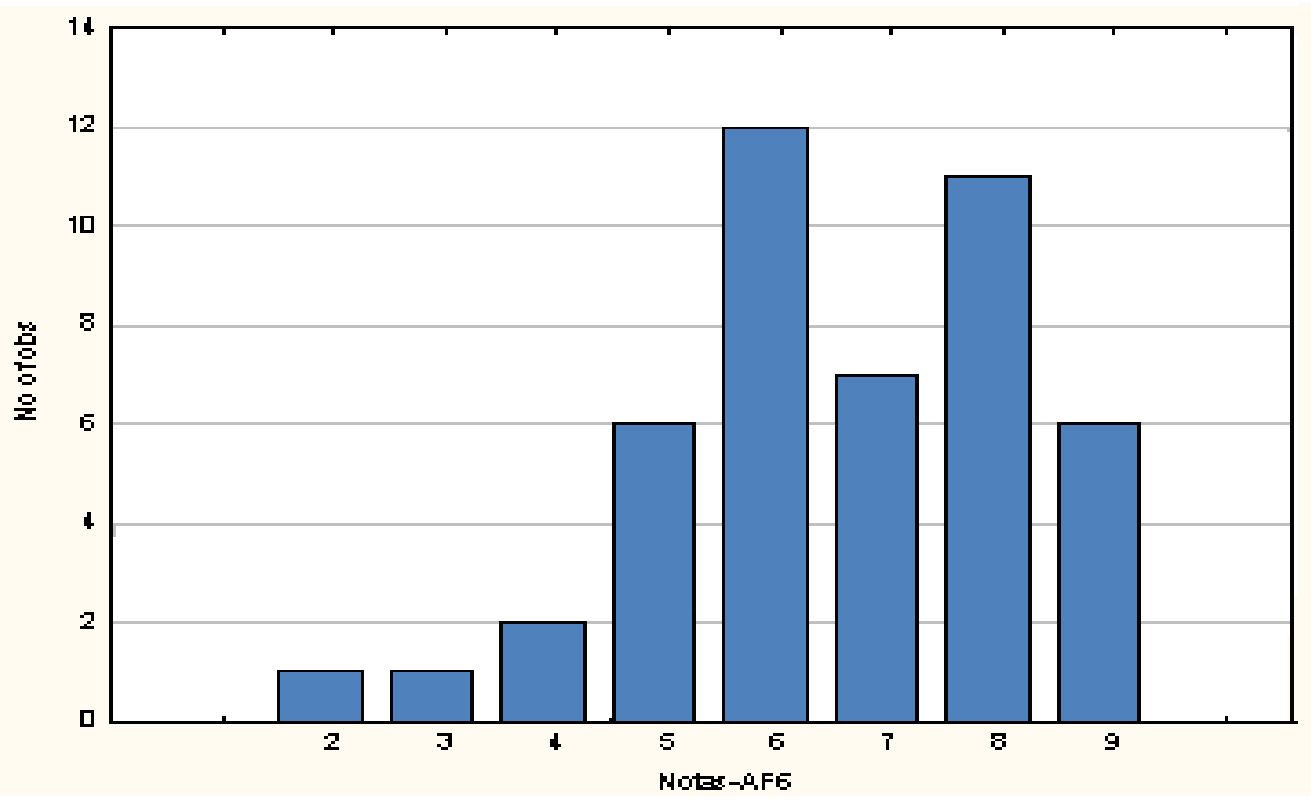

Figura 44: Gráfico que indica as notas atribuídas pelos professores à afirmação 6 . 


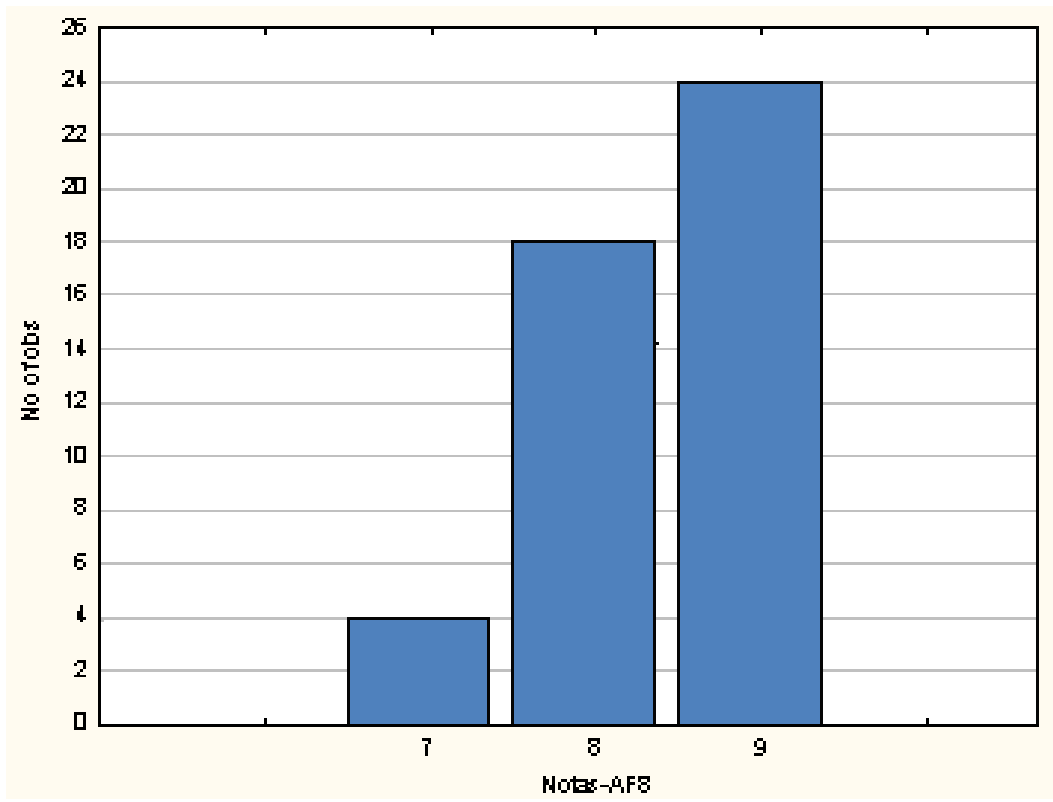

Figura 45: Gráfico que indica as notas atribuídas pelos professores à afirmação 8.

Para a afirmação 11 (Gráfico 46): "Qualquer explicação ou descrição que fazemos da realidade está associada à nossa própria experiência", se obteve uma média de 7.3, o que significa que em geral, os professores concordaram moderadamente com esta afirmação. Não se trata de puro relativismo e sim de que ao explicarmos um fenômeno utilizamos nossos conhecimentos e experiências, nossa história de vida. Dificilmente teremos duas pessoas interpretando a realidade ou um fenômeno da mesma maneira, portanto em sala de aula é papel do professor levantar todas as explicações possíveis e, juntos professor e alunos, chegarem a um domínio comum de explicação, através de uma validação de conceitos.

Para a afirmação 12 (Gráfico 47): "Todas as explicações que um indivíduo dá sobre a realidade são válidas e legítimas, mesmo que os outros as considerem erradas", se obteve uma média de 5.7, o que significa que em geral, os professores concordaram ligeiramente com esta afirmação. A ideia de que todas as explicações são válidas e legítimas parece incomodar bastante os professores, como veremos adiante na análise de textos escritos por eles e como podemos observar na dispersão das respostas no gráfico abaixo. Em sala de aula todas as explicações são válidas, dentro de um contexto determinado, o que não significa que estas explicações sejam válidas do ponto de vista científico ou erudito. O que queremos destacar nesta afirmação é que como professores no exercício da profissão é 
fundamental aceitar a explicação do outro, mesmo que não nos agrade ou mesmo que não concordemos, pois assim permitimos que o nosso aluno, o outro, se exponha e através da linguagem, nas interações do grupo, gere um processo reflexivo sobre o assunto e desta forma possam ocorrer transformações.

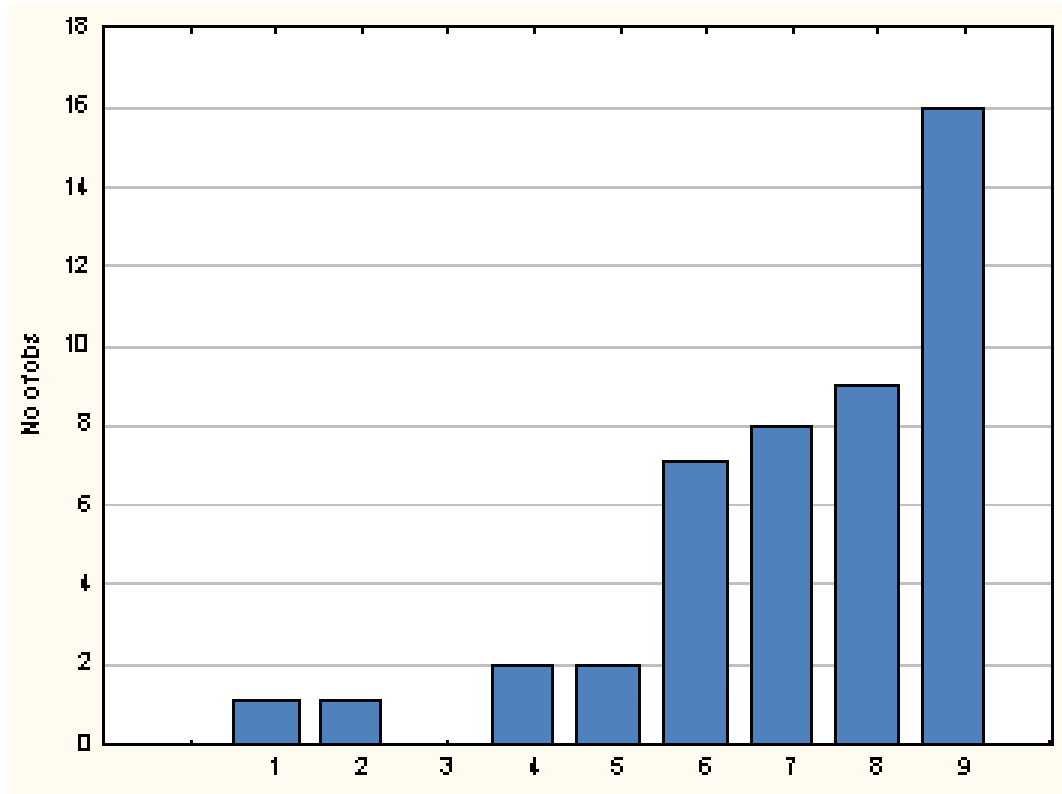

Figura 46: Gráfico que indica as notas atribuídas pelos professores à afirmação 11

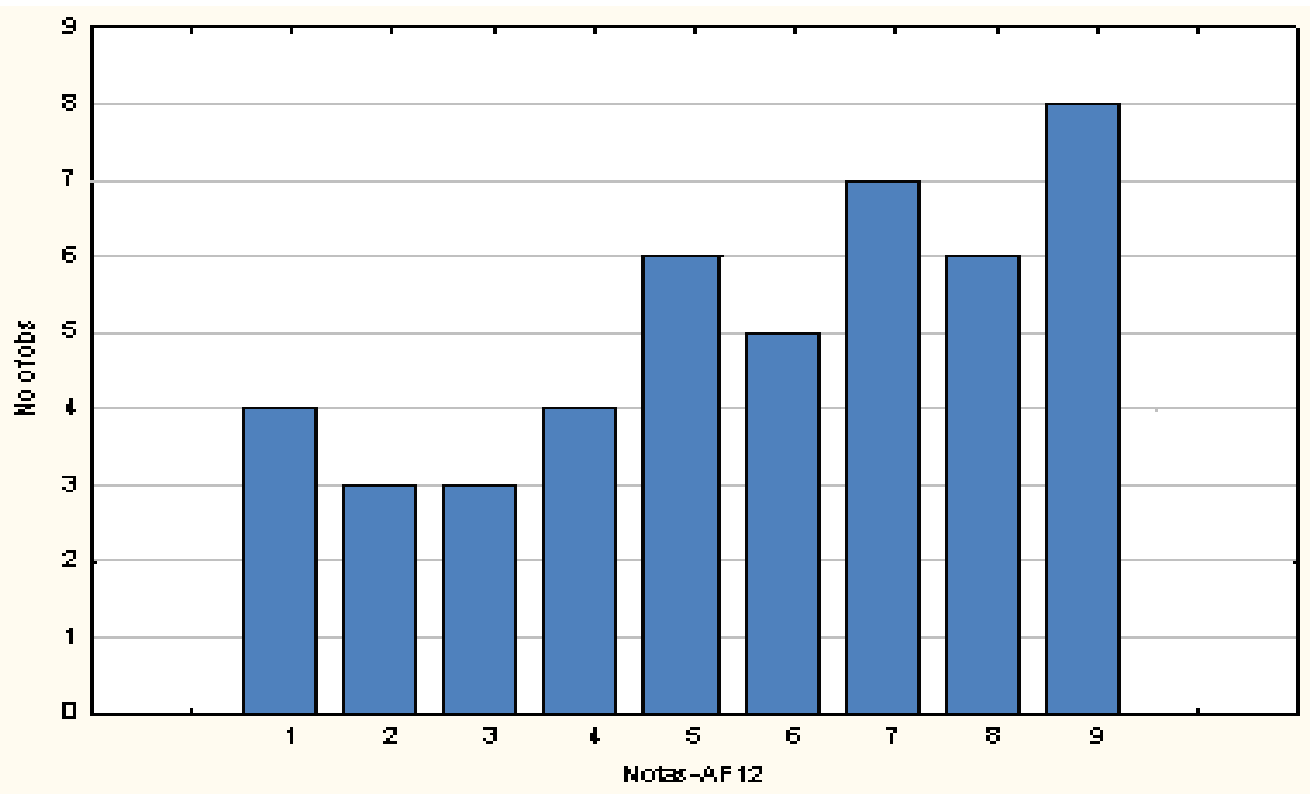

Figura 47: Gráfico que indica as notas atribuídas pelos professores à afirmação 12. 
Para a afirmação 14 (Gráfico 48): "Para que a sala de aula seja um espaço de promoção da inteligência e da criatividade dos alunos, não se pode avaliar a pessoa do aluno, apenas avaliar o que esse aluno faz.", se obteve uma média de 5.1, o que significa que em geral, os entrevistados não concordaram nem discordaram desta afirmação, verificamos também grande variabilidade de respostas e a formação de dois grandes grupos, os que concordam e os que discordam com a afirmação, o que indica que a interpretação da afirmação foi bastante variada.

Esta afirmação desde o início da pesquisa causou estranheza para os professores que participaram do pré-teste. Quando nos referimos à escola como local de promoção da inteligência e da criatividade, muitos professores aceitam este conceito de escola, mas indicar que não se pode avaliar a pessoa do aluno e sim o seu fazer, causa certo desconforto aos professores. Acreditamos que no final do bimestre estamos acostumados, como professores, a "dar a nota ao aluno" e parece que este processo se torna equivalente a uma avaliação pessoal e não das produções, o fazer, deste aluno. Esta ideia está tão enraizada na prática educativa dos professores que ao responder a este opiniário, em muitos deles aparecia a preocupação de serem avaliados como pessoas. Esta preocupação se tornou evidente nas falas e também nos textos produzidos por eles, como veremos adiante.

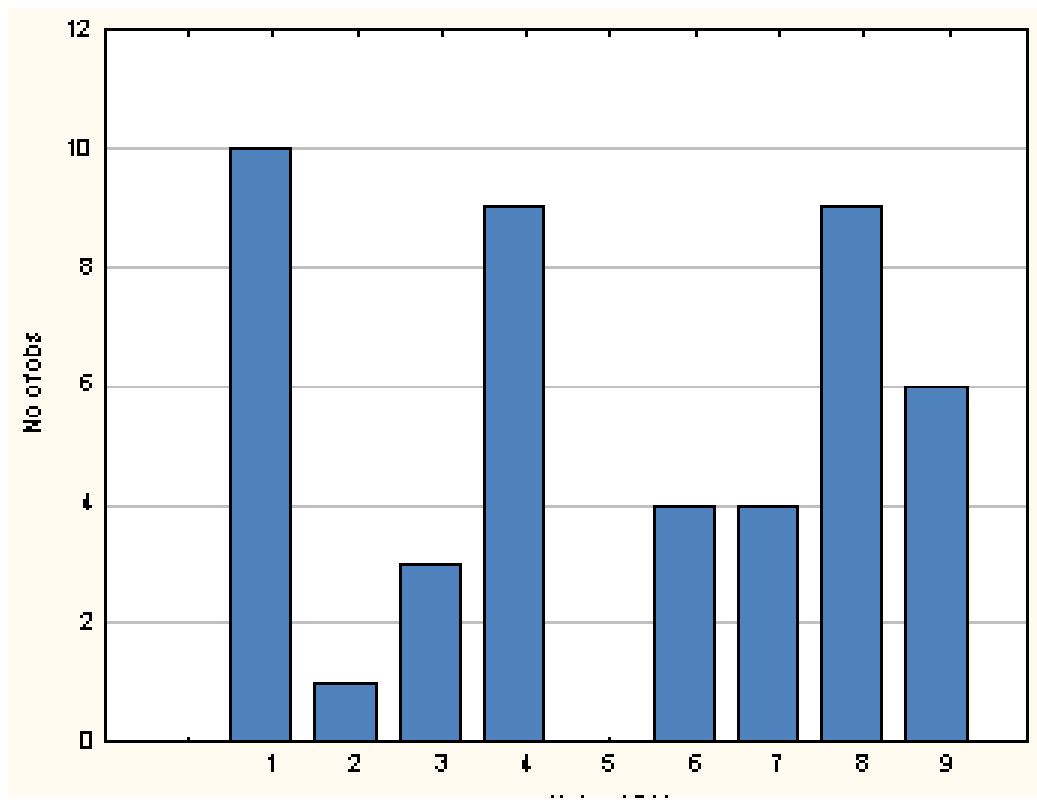

Figura 48: Gráfico que indica as notas atribuídas pelos professores à afirmação 14. 
Para a afirmação 15: "As nossas emoções mudam nossas ações e em consequência, mudam também a forma de nos comunicarmos e a nossa maneira de pensar", se obteve uma média de 7.2, o que significa que em geral, os professores concordaram moderadamente com esta afirmação. Com relação à ideia que a emoção gera mudanças em nossas ações e comportamentos parece não haver muita dúvida entre os professores, mas ainda podemos observar no gráfico a dificuldade de alguns professores em aceitar isso. Provavelmente para esses professores a razão é o que conduz e norteia a nossa comunicação e a nossa maneira de pensar.

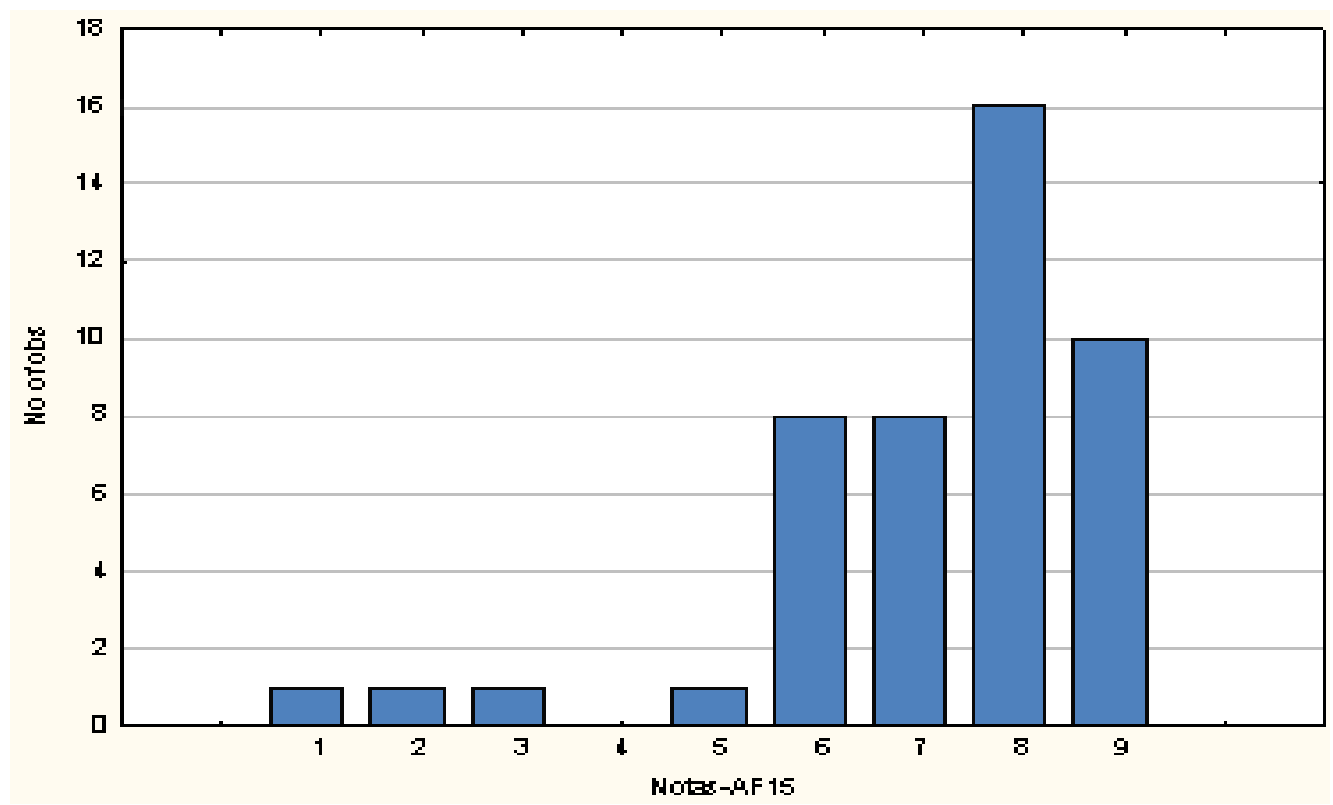

Figura 49: Gráfico que indica as notas atribuídas pelos professores à afirmação 15.

A seguir discutiremos brevemente as afirmações nas quais houve diferenças significativas entre as pontuações atribuídas pelos professores.

Para as respostas dadas às afirmações 7, 9, 10 (Figuras 50, 51 e 52) foram obtidas diferenças significativas $(p \leq 0,05)$ em relação ao sexo, tempo de serviço e faixa etária, respectivamente. A afirmação 13 (Figura 53) apresentou diferenças estatísticas significativas no grau de concordância dos entrevistados tanto em relação ao sexo como na disciplina que ministra na escola $(p \leq 0,05)$.

A afirmação 7 (Figura 50): "Em sala de aula, as interações entre os indivíduos provocam mudanças de comportamentos uns nos outros e isso gera 
transformações", apresentou diferenças estatísticas significativas em relação ao sexo $(p \leq 0,05)$ dos professores participantes. A nota média dos homens (7.6) foi significativamente menor que a nota média das mulheres (8.3). Este resultado era esperado, pois acreditamos que ao falar de interações humanas e emoções em sala de aula as mulheres se mostram mais abertas a estes temas do que os homens, as professoras parecem acreditar mais em mudanças do que os professores, independente da disciplina que ministram. Certamente esta é uma generalização o que não exclui a possibilidade que professores homens, acreditem em mudança e transformação.

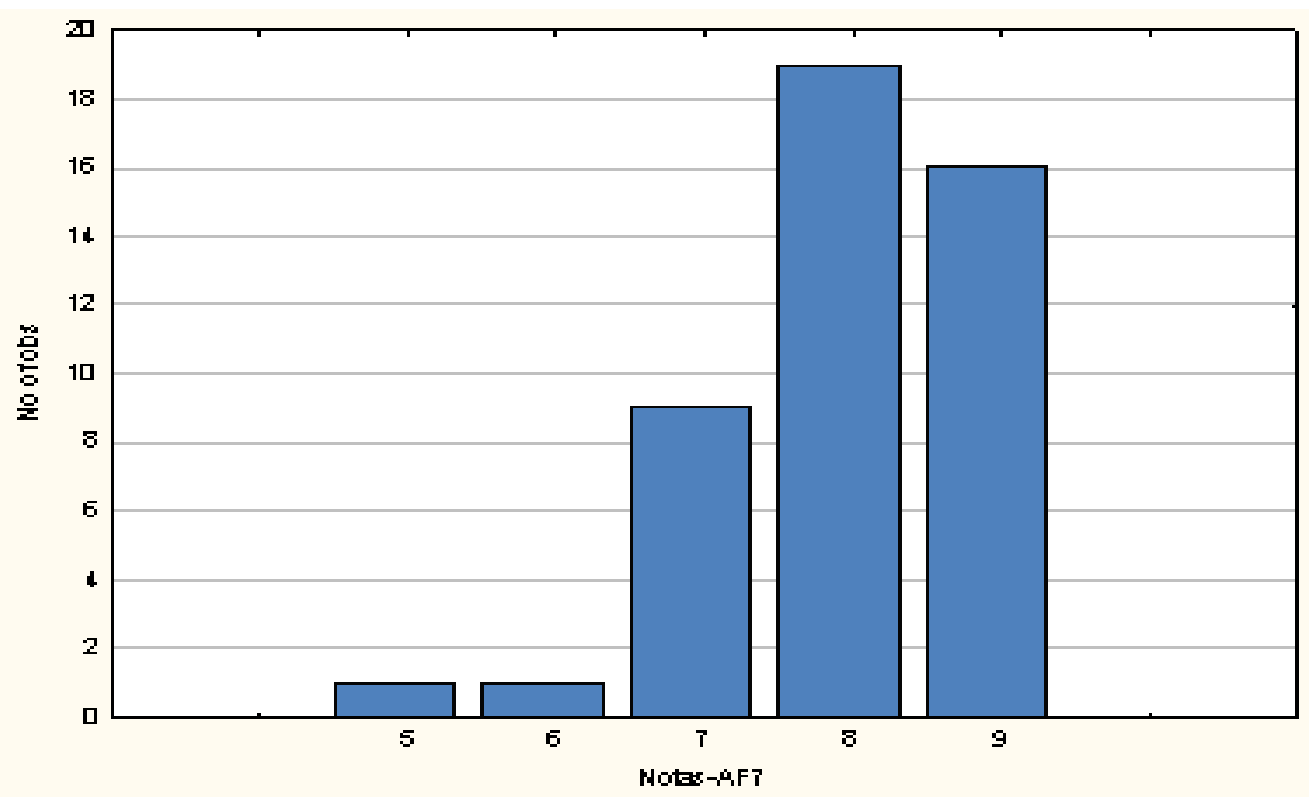

Figura 50: Gráfico que indica as notas atribuídas pelos professores à afirmação 7 .

A afirmação 9 (Figura 51): "Através da linguagem nos tornamos seres mais conscientes de nós mesmos e conscientes do mundo" apresentou diferenças estatísticas significativas $(p \leq 0,05)$ em relação ao tempo de serviço, sendo que os professores com menos de 5 anos de serviço atribuíram uma nota média de 7.8, enquanto os professores com maior tempo de serviço atribuíram notas médias em torno de 8.5, mostrando assim seu maior grau de concordância em relação a esta afirmação. Este resultado coincidiu com nossa hipótese inicial para esta questão, pois acreditamos que a experiência em sala de aula permite ao professor identificar a importância da linguagem para as interações uns com os outros e também com o 
ambiente em que se vive, permitindo assim uma maior consciência de nós mesmos e de nossas ações.

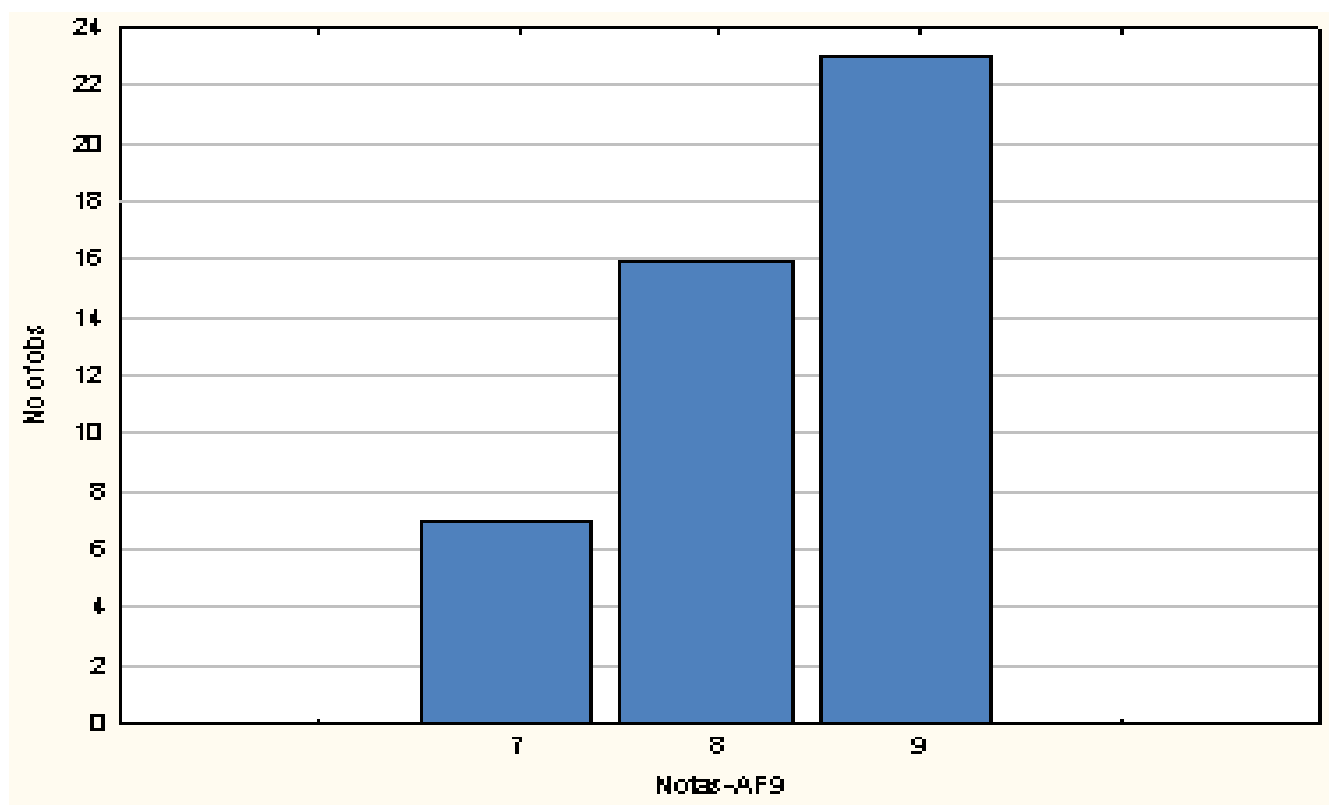

Figura 51: Gráfico que indica as notas atribuídas pelos professores à afirmação 9.

A afirmação 10 (Figura 52): "Quando afirmamos que somos seres racionais, menosprezamos as emoções e exaltamos a racionalidade" apresentou diferenças estatísticas significativas $(p \leq 0,05)$ em relação à faixa etária, sendo que os professores com idades entre 18 a 34 anos apresentaram notas médias em torno de 5.0 (nem concordo /nem discordo), já os professores com idades entre 35 a 44 anos apresentaram notas médias em torno de 6.0 (concordo ligeiramente), enquanto os professores com idades entre 45 a 54 anos apresentaram uma nota média em torno de 3.0 (discordo moderadamente) e os professores maiores de 54 anos apresentaram uma nota média em torno de 6.0 (concordo ligeiramente).

Estes resultados mostram que o grau de concordância em relação a esta afirmação foi bastante diferenciado nas diversas faixas etárias. As divergências nas respostas e na análise estatística pode ser consequência da dificuldade de interpretação da própria afirmação.

A afirmação 13 (Figura 53): "Através da conversação e da linguagem na sala de aula o professor pode abrir caminhos para a reflexão. Desta forma seu aluno não será negado em suas dificuldades e sim respeitado como um ser individual, único e 
legítimo" apresentou diferenças estatísticas significativas em relação ao sexo $(p \leq 0,05)$ e à disciplina $(p \leq 0,05)$. Em relação ao sexo, ambos os grupos mostraram alto grau de concordância em relação a esta afirmação, mesmo assim, a nota média dos homens (7.8) foi significativamente menor que a nota média das mulheres (8.5). Já em relação às diferenças na disciplina, apesar dos professores das diversas disciplinas manifestaram seu alto grau de concordância para esta afirmação, os professores de Física, Química e Biologia apresentaram um grau de concordância ligeiramente maior que professores de Matemática.

Essa diferença no grau de concordância entre homens e mulheres já era esperada, pois mais uma vez podemos observar que ao trabalhar emoção e comunicação, ao mesmo tempo, as mulheres apresentam uma maior concordância com o assunto. Quanto às diferenças entre as respostas dos professores de matemática em relação às outras disciplinas podemos interpretá-las como sendo devido ao professor desta disciplina não trabalhar com os fenômenos naturais, com o cotidiano ou de certa forma com o concreto, como o fazem de alguma forma mesmo que utilizando modelos e analogias, professores de Biologia, Química e Física, e sim com uma linguagem, a linguagem matemática que de fato é abstrata.

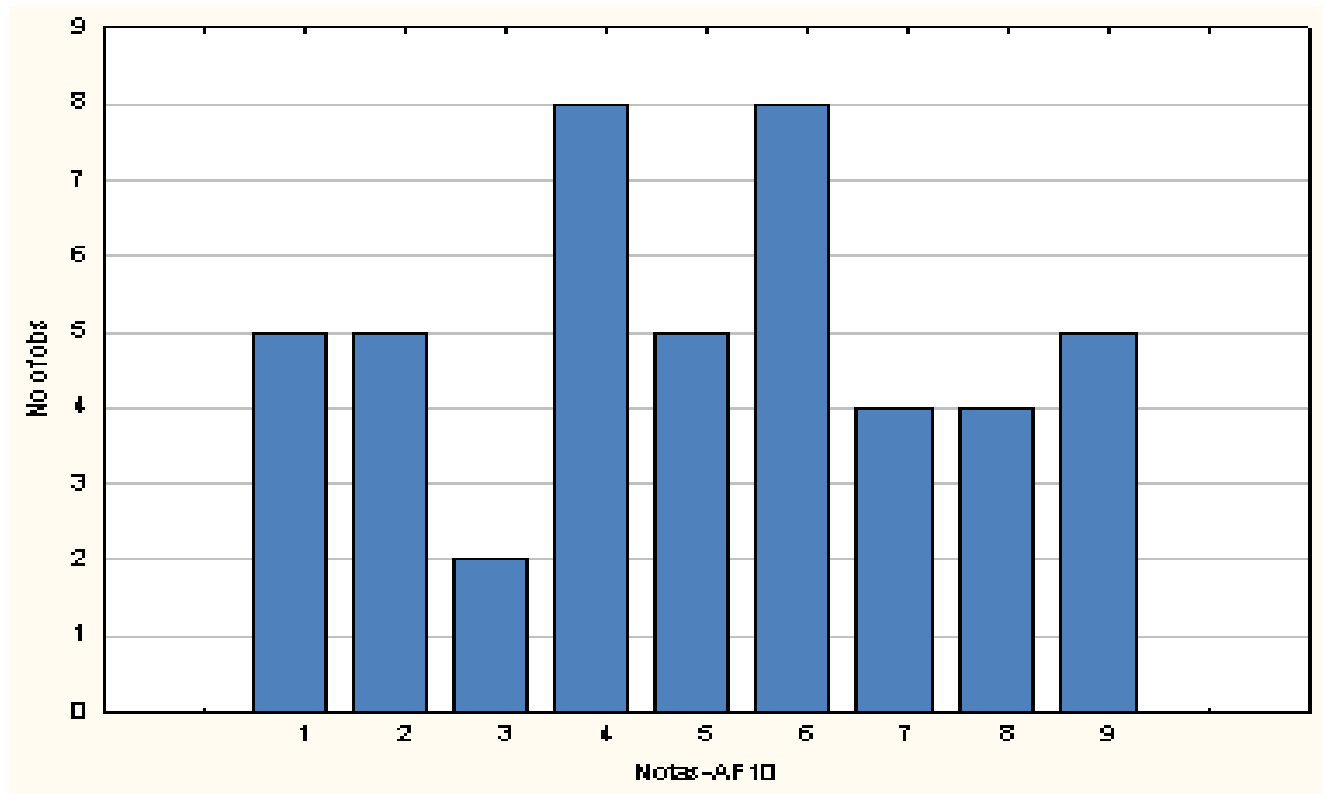

Figura 52: Gráfico que indica as notas atribuídas pelos professores à afirmação 10. 


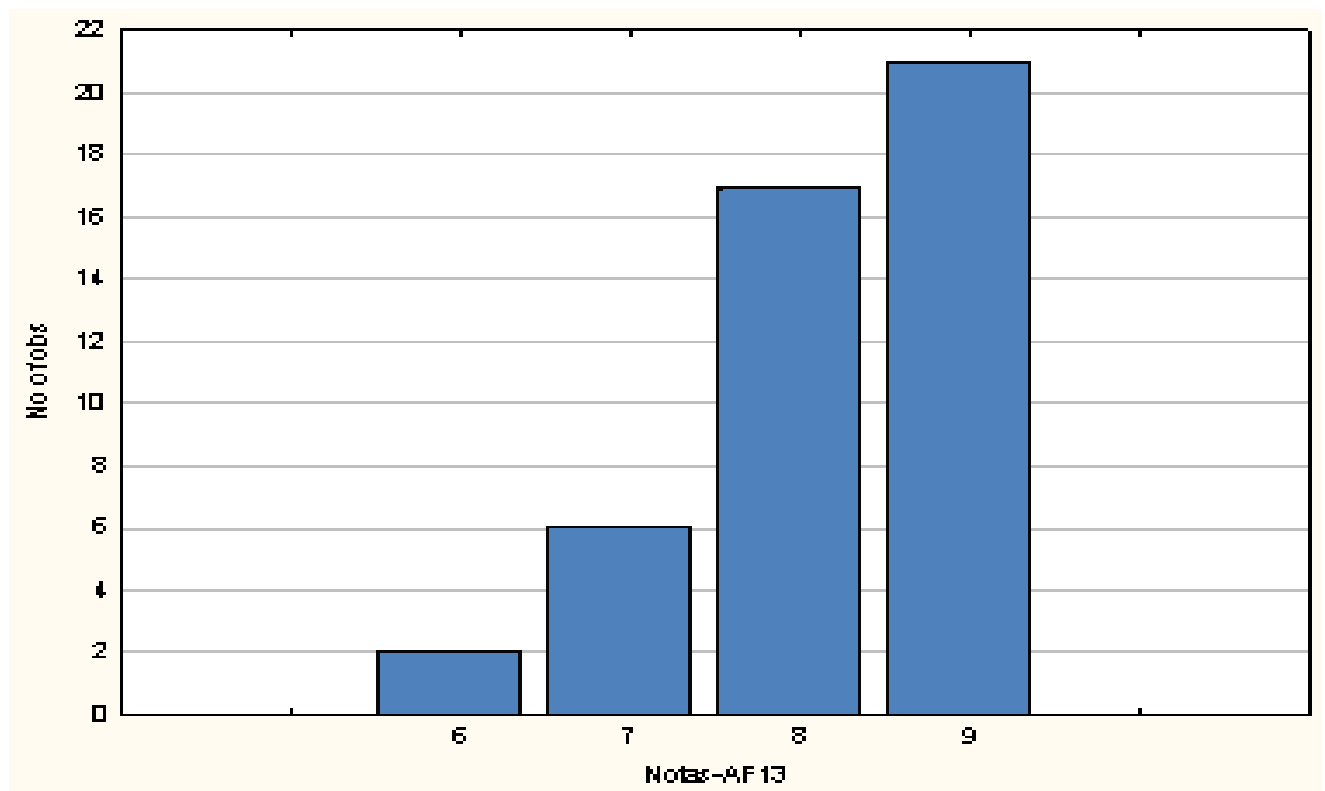

Figura 53: Gráfico que indica as notas atribuídas pelos professores à afirmação 13.

\subsection{Análise das perguntas abertas do opiniário}

Com a finalidade de fazer também uma análise qualitativa dos dados obtidos, os 46 professores que participaram da pesquisa responderam por extenso a quatro questões, que foram transcritas na íntegra (Anexos 8 e 9), e que serviram para delinear o perfil da amostra quanto ao conhecimento ou não das ideias de Humberto Maturana. Estas questões permitiram a elaboração de categorias empíricas e a identificação de unidades de análise. Através deste opiniário obtivemos a informação que dos 46 professores de nosso estudo exploratório, apenas 10 tinham pelo menos ouvido falar do autor e referencial teórico deste trabalho, Humberto Maturana.

Das obras publicadas por Maturana foram citadas, em ordem decrescente de frequência, a "Árvore do Conhecimento", "A ontologia da realidade", "De máquinas e seres vivos", "Emoções e Linguagem", "Cognição, ciência e vida cotidiana".

Ao perguntarmos aos professores se este autor poderia contribuir com a melhoria do ensino nas escolas, 17 professores que responderam a questão o fizeram de maneira afirmativa.

Para realizar as análises das produções textuais dos professores, que aceitaram participar desta pesquisa, foram utilizadas as três categorias teóricas 
selecionadas a priori, já mencionadas no trabalho, a saber, a razão, a emoção e a linguagem, conceitos fundamentais da Biologia do Conhecer de Humberto Maturana. Estas categorias teóricas foram utilizadas para identificar e confrontar as ideias dos professores da nossa amostra com as de Humberto Maturana, uma vez que, como afirma Moraes (2003), as teorias estão presentes em todas as etapas da análise do discurso. Como as categorias teóricas já estavam definidas consideramos como método para esta análise dos textos produzidos pelos professores, o método dedutivo. Neste método dedutivo as categorias teóricas são construídas antes de se ler o corpus do texto a partir de teorias que servem de fundamentos para a pesquisa, formando assim as categorias a priori, onde as unidades de análise serão identificadas e organizadas.

Para Moraes (2003) os materiais textuais possuem significantes, aos quais o analista ou pesquisador precisa atribuir sentidos e significados. Portanto, se a atribuição do significado é dada pelo analista, no caso o pesquisador, podemos considerar a multiplicidade de leituras geradas a partir de um texto, pois a multiplicidade de significados que se constroem depende dos diferentes pressupostos teóricos utilizados nas leituras de cada analista ou pesquisador. E como o nosso autor e referencial teórico indica insistentemente na sua obra, tudo depende do observador.

Desta forma realizamos uma leitura denotativa dos textos produzidos pelos professores onde, segundo Moraes (2003) as interpretações podem ser compartilhadas entre os leitores, pois as unidades de análise são mais explicitas. De acordo com Moraes, existe uma leitura mais implícita, que exige uma interpretação exigente e aprofundada e que não é compartilhada facilmente por diferentes autores, a que ele chama de leitura conotativa. Em ambas as leituras as interpretações partem dos conhecimentos e teorias de cada leitor.

Assim, determinamos algumas categorias empíricas que surgiram a partir da leitura do corpus do texto, ou seja, das respostas dadas à questão 3 (Apêndice 9), que foram organizadas na tabela abaixo, lembrando que essa leitura já é uma interpretação e, portanto não é única e objetiva (Moraes, 2003). 


\begin{tabular}{|c|c|c|c|}
\hline $\begin{array}{l}\text { CATEGORIAS } \\
\text { TEÓRICAS }\end{array}$ & CATEGORIAS EMPÍRICAS & $\begin{array}{l}\text { ELEMENTOS } \\
\text { COMUTÁVEIS }\end{array}$ & UNIDADES DE ANÁLISE \\
\hline \multirow[b]{2}{*}{ RAZÃO } & $\begin{array}{l}\text { Razão genérica } \\
\text { (3 professores) }\end{array}$ & Razão, clareza & $\begin{array}{l}\text { "a razão e a emoção andam juntas } \\
\text { não somos seres dicotômicos" } \\
\text { prof.12 } \\
\text { " Falta de clareza e confusão } \\
\text { epistemológica e metodológica" } \\
\text { prof.08 }\end{array}$ \\
\hline & $\begin{array}{l}\text { Aprendizagem } \\
\text { (6 professores) }\end{array}$ & $\begin{array}{l}\text { cognição, } \\
\text { aprendizagem }\end{array}$ & $\begin{array}{l}\text { "Toda produção humana realizada } \\
\text { no intuito de conhecer os caminhos } \\
\text { da cognição é de grande valia para a } \\
\text { Sociedade"prof.06 } \\
\text { "Estou certa de que meus alunos } \\
\text { aprendem aquilo que tem } \\
\text { significado em suas vidas" prof. } 28 \\
\text { " múltiplas dimensões que nos } \\
\text { constituem estão inter-relacionadas } \\
\text { no processo de aprender" prof. } 30\end{array}$ \\
\hline \multirow{6}{*}{ EMOÇÃO } & \multirow{2}{*}{$\begin{array}{l}\text { Relações humanas } \\
\text { (6 professores) }\end{array}$} & $\begin{array}{l}\text { Interações } \\
\text { professor/aluno }\end{array}$ & $\begin{array}{l}\text { "aceitação legítima do outro põe em } \\
\text { evidência a relação professor-aluno } \\
\text { e como esta pode ser reconhecida } \\
\text { como legitima" prof. } 26\end{array}$ \\
\hline & & Interações sociais & $\begin{array}{l}\text { "no ambiente escolar porque ocorre } \\
\text { fenômenos sociais, como as } \\
\text { emoções, os pensamentos, os } \\
\text { conceitos e através dessas } \\
\text { interações" prof. } 29\end{array}$ \\
\hline & \multirow{3}{*}{$\begin{array}{l}\text { Conceitos vinculados à } \\
\text { emoção } \\
\text { (5 professores) }\end{array}$} & Respeito & $\begin{array}{l}\text { "uma relação respeitosa } \\
\text { harmoniosa em sala de aula, onde } \\
\text { professor e alunos se respeitam e } \\
\text { respeitam as diversas opiniões" } \\
\text { prof.02 }\end{array}$ \\
\hline & & Confiança & $\begin{array}{l}\text { "o aluno, sentindo-se seguro para } \\
\text { expor suas opiniões" prof.02 }\end{array}$ \\
\hline & & Amorosidade & $\begin{array}{l}\text { "a conversa e a amorosidade } \\
\text { passam a ter um papel importante } \\
\text { na ação educativa" prof. } 20\end{array}$ \\
\hline & $\begin{array}{l}\text { Emoção genérica } \\
\text { (9 professores) }\end{array}$ & Emoção & $\begin{array}{l}\text { "sei que ele propõe uma nova } \\
\text { visão de homem, considerando a } \\
\text { emoção. Eu acredito muito que esta } \\
\text { visão possa contribuir para o ensino } \\
\text { nas escolas" prof. } 16 \\
\text { Este deve sempre refletir e lembrar } \\
\text { que assim como ele próprio, seus } \\
\text { alunos possuem emoções" prof.39 } \\
\text { "Cada novo aprender auto-organiza } \\
\text { todo o nosso corpo (físico, } \\
\text { cognitivo, emocional, } \\
\text { afetivo...)"prof.30 }\end{array}$ \\
\hline
\end{tabular}




\begin{tabular}{|c|c|c|c|}
\hline & $\begin{array}{c}\text { Conversa } \\
\text { (3 professores) }\end{array}$ & Conversação & $\begin{array}{l}\text { "Outro fato importante considerado } \\
\text { pelo Maturana é a Linguagem e a } \\
\text { Conversação" prof. } 39\end{array}$ \\
\hline LINGUAGEM & $\begin{array}{l}\text { Expor opiniões } \\
\text { (3 professores) }\end{array}$ & Dar opinião & $\begin{array}{l}\text { "não dá espaço para o aluno } \\
\text { explicitar suas experiências e } \\
\text { compreensões." } \\
\text { "seguro para expor suas opiniões, } \\
\text { dúvidas e pensamentos, pode } \\
\text { aproveitar melhor o conhecimento } \\
\text { compartilhado em sala" prof. } 02\end{array}$ \\
\hline
\end{tabular}

Tabela 2: Trechos dos textos escritos por professores relacionados a questão 3 que foram incluídos em categorias teóricas e empíricas.

Por outra parte, chamamos de elementos comutáveis aquelas palavras ou expressões presentes nos textos dos professores e que nos ajudaram a identificar e a organizar as unidades de análise. A escolha do termo elementos comutáveis surgiu da leitura do livro "Organismos, estruturas, máquinas: para uma teoria do organismo" de Wolfgang Wieser (1972, p.13). Para o autor esses elementos comunicam-se entre si, desenvolvendo inter-relações regulares e coerentes. "Essas redes de comutações servem para transportar notícias, sinais, numa palavra: informação"

O que indicou para nós a coerência de utilizar a expressão elementos comutáveis neste trabalho, foi o sentido atribuído por Wieser para estes, e a ideia de Maturana da impossibilidade de se separar razão, emoção e linguagem. Essas palavras ou expressões que chamamos de elementos comutáveis transitam de uma categoria de análise para outra e formam redes de informação, circulares entre si. Neste trabalho, precisávamos de elementos que permitissem essa inter-relação e certa flexibilidade.

A Tabela 2 contém trechos de algumas respostas abertas à questão 3 do opiniário. Podemos observar, nos textos produzidos pelos professores ao responderem a questão 3: Crê que este autor pode dar uma contribuição para o ensino nas escolas? Em caso afirmativo, explique brevemente suas razões, que muitos consideraram a emoção como elemento essencial à educação, às interações em sala de aula e às interações sociais. Porém, a razão é valorizada, e a sua busca é ainda maior, isto se torna evidente na resposta dada pelo professor 28 : 
[...] Como Educadora, acredito que a aprendizagem é feita por meio da relação, de uma boa relação. Estou certa de que meus alunos aprendem aquilo que tem significado em suas vidas e, a capacidade de dar significado ao conhecimento é de cunho do Professor [...] (grifo nosso)

Podemos observar que o professor considera a aprendizagem relacionada com uma boa relação, ou seja, as emoções fluindo de maneira positiva, mas quando ele diz "que a capacidade de dar significados ao conhecimento" expõe a preocupação que o mesmo tem com a racionalidade, com a razão. Isto nos mostra como a ideia do professor detentor do conhecimento e capaz de transmiti-lo ou de torná-lo significativo está presente neste professor.

Outro exemplo vem da resposta do professor 06 que indica neste trecho a preocupação com o cognitivo, com o conhecimento.

[...] Acredito, mesmo não conhecendo o trabalho do autor. Toda produção humana realizada no intuito de conhecer os caminhos da cognição é de grande valia para a Sociedade [...] (grifo nosso)

A constante preocupação com a razão e a busca pela clareza de pensamentos está representada pelo professor 08, que diz que "o que temos em sala de aula hoje em dia, é falta de clareza e confusão epistemológica e metodológica".

Em relação às interações humanas imprescindíveis para a educação, sendo proposta como resposta para a crise na educação, como cita o prof. 26 ou necessárias para que haja um "diálogo de verdade" (prof.27) nos leva a afirmar que alguns destes professores identificam a intrínseca relação entre linguagem, emoção e razão:

[...] Sim. A escola é uma instituição alicerçada nas relações humanas e um olhar mais profundo sobre essas relações pode oferecer alternativas à crise que a escola vem sofrendo nos últimos anos. [...] (prof. 26)

[...] Creio que sim, pelas afirmações que li aqui, acredito que a maior contribuição seja ajudar-nos a repensar as relações humanas, como se estabelecem, quais seriam as condições de atitude racional e afetiva para que um diálogo de verdade possa ser estabelecido entre professor e aluno [...] (prof. 27)

As respostas dadas a questão 4 "Ao responder este opiniário algumas reflexões podem ter surgido. Este espaço é destinado para as suas reflexões, críticas e comentários que você ache pertinentes. Sinta-se a vontade para escrever 
seus comentários, os quais serão de grande valia para este trabalho de pesquisa", que na sua maioria são de cunho pessoal, nos permitiram através de uma análise do texto, identificar três tipos de temas, como indicado na tabela abaixo:

\begin{tabular}{|c|c|}
\hline ASSUNTO DO TEXTO & PROFESSOR \\
\hline Comentários à elaboração do questionário & $05,06,19,27,30,33,37$ \\
\hline Reflexões teóricas & $01,11,12,15,17,20,24,34,41,42,43$ \\
\hline Comentários pessoais & $09,16,18,23,27,28,35$ \\
\hline
\end{tabular}

Tabela 3: Classificação dos assuntos abordados pelos professores na pergunta 4 do opiniário.

A seguir analisaremos alguns trechos que consideramos mais significativos das respostas à questão 4.

Ao comentar a elaboração do opiniário, alguns professores manifestaram uma dificuldade em entender a frase, muitas vezes nomeando a linguagem utilizada como complexa ou com dualidade de sentidos:

[...] A linguagem utilizada nas afirmações é um pouco complexas demais [...] (prof.19)

[...] Algumas afirmações tem mais de uma afirmação dentro delas [...] (prof.05)

[...] "Através da conversação e da linguagem." não compreendo como coisas distintas ou separadas [...] (prof.30)

Um dos objetivos da pesquisa era justamente conhecer o quanto as concepções de razão, linguagem e emoção dos professores de ciências se aproximavam ou não das concepções de Maturana, e para estudar isto utilizamos frases adaptadas das obras do autor. Estas frases foram simplificadas com cuidado para que não perdessem o sentido atribuído pelo autor. Humberto Maturana demonstra em sua maneira de escrever, uma circularidade, onde razão, emoção e linguagem estão tão intrinsecamente relacionadas, que se torna quase impossível 
separá-las, o que provavelmente gerou em alguns professores a impressão de duplo sentido.

O professor 30 não distingue linguagem de conversação, mas para Maturana há diferenças entre estes dois termos ou conceitos. A linguagem para ele é um fluir de coordenações consensuais de condutas, que podemos chamar de ações e quando essa linguagem se entrelaça com as emoções levando a convivência com outros, Maturana chama isso de conversação.

Outro obstáculo aparente para os professores foi a utilização da palavra amor, esta incomodou bastante àqueles que respondiam ao opiniário, o que gerou algumas discussões extras e pudemos perceber várias reações dos professores, como risadas, silêncios profundos e algumas "caretas". Alguns deles de maneira jocosa falavam do amor e o relacionavam com o afeto em sala de aula, mostrando uma conotação negativa e muito associada à pedagogia do afeto de Gabriel Chalita, quando este era o Secretário da Educação, e para o qual o afeto é "jeito delicado de o professor corrigir o aprendiz, na forma serena de explicar, de transmitir informações, de tirar dúvidas" (trecho retirado de uma entrevista no site www.gabrielchalita.com.br).

[...] No opiniário, você utilizou o termo amor. Acredito que dentro os entrevistados possam haver concepções divergentes quanto ao termo que possam influenciar as respostas. [...] (prof.06)

[..] No processo de interação professores e estudantes mais importante do que o Amor (que considero um sentimento fortíssimo e poderoso) é o respeito que devemos ter [...] (prof.42)

[...] não concordo que o amor seja condição espontânea para a aceitação do outro [...] (prof. 27)

Aparentemente a emoção amor é associada por estes professores, com um sentimento abstrato valorizado, "poderoso" e buscado por todos os seres humanos, e quando nos referimos a ele de maneira mais simples e concreta, como sendo um fenômeno biológico capaz de permitir interações entre os seres humanos, causa estranhamento e não aceitação.

Falar de amor como um fenômeno biológico tem se mostrado um grande problema, Maturana escreve em seus livros e artigos a dificuldade que ele mesmo tem ao falar de amor em suas palestras e cursos: 
[...] Sempre que falo de amor minha audiência, qualquer que seja ela, se inquieta. Amor é uma palavra perigosa. Parece que normalmente pensamos que o amor é humano demais para ser acessível às reflexões de um cientista [...] (Maturana, 1997, p.183)

Para Maturana o amor é a emoção que está na base da humanidade, do social e de nossas reflexões éticas, ele é o fundamento do fenômeno social e não o contrário.

O amor é a emoção necessária para que se abra espaço para as interações sociais e é através dele que enxergamos o outro como legítimo outro, na convivência, no respeito e na confiança, sem ele não há humanidade.

[...] Isto não é uma apologia do amor. Isto é apenas um convite a refletirmos sobre a condição biológica que é a base da humanidade [...] Não estou sequer recomendando o amor. Estou apenas dizendo que, sem o amor como um fenômeno biológico espontâneo, não existe socialização [...](Maturana, 1997, p.186)

Precisamos repensar o amor dentro da sala de aula como uma "força conectiva que nos liga ao todo e, ao mesmo tempo se constitui na nossa autoafirmação". (Pellanda, 2009 p.83).

O trecho abaixo do professor 27 foi transcrito na íntegra, porém os grifos são nossos:

[...] Na afirmação 4, não concordo que o amor seja condição espontânea para a aceitação do outro. Acho que é condição essencial, porém trabalho da Vontade. Na questão 2, não concordo que as emoções definam a racionalidade, mas que ambas se construam mutuamente. Na questão 5 , não sei se é exclusivamente o amor que nos mantém unidos ou com um sentimento de identificação como "humanidade", talvez seja isso, mas acho que existem outros fatores como a necessidade do outro, o interesse, o "uso do outro" como fator de agregação temporária, ou desagregação social... Nossa história evolutiva quer dizer nossa "não extinção como espécie"? Acho que o afeto está nos mamíferos, com certeza, e faz criar laços. Não sei se a inteligência, memória e engenhosidade não tiveram um papel fundamental... Acho que o amor está em extinção (se se aprende a amar sendo amado... e amando por decisão, mais que por esperança...). Acho que só por um Amor Maior (Deus) é possível ainda alguma Esperança para o ser humano e para a Terra. Acho que o nosso amor é uma resposta quase milagrosa a esse amor maior. Acho que pela confiança que o amor gera é possível que alguém aceite deixar-se tocar, deixar-se transformar e recomeçar, e assim crescer como pessoa, não apenas cognitivamente. Questão 8, acho que a linguagem nos ajuda a "entender" ou "explicar" o que sentimos de forma não racional, como na contemplação, que acho que está além da razão, que existe em nós antes da palavra. Questão 9, conscientes da explicação que damos para nós mesmos e para o mundo... o que é meio limitado de certa maneira (parece um paradoxo), acho que pela relação que estabelecemos com as pessoas e o mundo nos conhecemos. Achei muito 
bacana pensar sobre tudo isso e me ajudou a me compreender melhor minha maneira de ser, e achar que "nem tudo está perdido" que o esforço de dialogar e amar pode valer a pena. Muito obrigada pela oportunidade!

Nesta resposta percebemos um conflito do professor, explicitado no texto que aparece às vezes antagônico. No início do trecho o professor nega que o amor seja condição espontânea para a aceitação do outro, não concorda que as emoções definam a nossa racionalidade, porém à medida que ele vai escrevendo, se observa o percurso reflexivo do professor sobre o assunto, e novas ideias vão surgindo no corpo do texto. O professor aceita o afeto que cria laços entre os mamíferos, mas o amor para ele está em extinção. Este professor ao falar de amor passa inevitavelmente pela religião e fala de um amor maior. Após uma reflexão ele chega a escrever:

[...] Acho que pela confiança que o amor gera é possível que alguém aceite deixar-se tocar, deixar-se transformar e recomeçar, e assim crescer como pessoa, não apenas cognitivamente [...]

Podemos observar que apesar de ter negado o amor no início do texto, neste trecho ele já mudou a sua maneira de pensar, já consegue ver o amor como necessário para "deixar-se transformar" pessoal e cognitivamente.

O professor no início do texto diz tacitamente que o amor está em extinção e após uma reflexão durante sua escrita, conclui "que o esforço de dialogar e amar pode valer a pena" (grifo nosso). Isso nos mostra a importância da reflexão e, principalmente como professores, como é necessário nos despir de nossas certezas sobre tudo.

Uma situação diferente aparece em um trecho do texto produzido pelo professor 28:

[...] Reitero que a gestão da sala de aula é de responsabilidade do Professor. Demonstrar respeito pelas diferenças e ter em mente a formação integral do ser humano [...]. Sei que a sala de aula é o meu lugar [...] Aprendi que, mais importante do que notas e resultados numéricos, é a forma como meus alunos utilizam os conhecimentos apreendidos em sala de aula para suas vidas e para a melhoria das condições de vida da Sociedade em que vivem. Sou MUITO feliz por estar à frente de uma sala de aula e sei que aqueles "olhinhos" apaixonados pela Biologia são parte daquilo que acredito: A Ciência como Verdade [...] (prof. 28, grifo nosso) 
No trecho acima o professor 28 descreve a sua paixão pela profissão e podemos perceber isso pela maneira que escreve e se coloca a respeito da Biologia e da própria educação. Ele descreve de maneira breve e ao mesmo tempo clara a sua relação com os seus alunos e a importância do que se apreende em sala de aula, para que seja utilizado na vida.

No entanto, podemos observar dentro desta fala que ao mesmo tempo em que ele demonstra a importância da emoção através dos "olhinhos apaixonados" de seus alunos, demonstra também uma visão ainda bastante racional e positivista, do ponto de vista epistemológico, quando afirma crer na "Ciência como verdade".

No texto produzido pelo professor 41 :

[...] Uma boa dose de percepção em relação a fraqueza ou carência do grupo e com palavras e atitudes adequadas pode-se criar um ambiente saudável de relacionamento (confiança) que venha promover a aprendizagem desejada. $\mathrm{Na}$ minha visão, não acredito que haja aprendizagem significativa num ambiente hostil. Conquiste o grupo. Assim terá todos ao seu lado, caminhando na mesma direção, mesmo que em velocidades diferentes. Haverá mais prazer de ambos os lados [...] (grifo do professor)

Ele expressa a necessidade em se construir um ambiente saudável, onde as interações e a aprendizagem aconteçam, mas alguns indícios no próprio texto nos permitem realizar outra interpretação do mesmo. Quando este professor diz "conquiste o grupo", pois "terá todos ao seu lado" "na mesma direção" nos parece dizer que se todos estiverem ao seu lado, não haverá nenhum aluno discordando, o que será "prazeroso" sem dúvida para o professor, mas não acreditamos que seja para o aluno. A maneira de enxergar o mundo ou de dar explicações a ele é única, e quando insistimos para que estes alunos caminhem juntos e deem as mesmas explicações aos fenômenos, provavelmente estaremos causando angustia e não o prazer do conhecimento. O importante é abrir espaços para que as explicações individuais apareçam mesmo em domínios diferentes, pois através da conversação o conhecimento emerge.

Observando o texto produzido pelo professor 15:

[...] As emoções são fatores inexoráveis de nossa existência e toda nossa linguagem nada mais é do que uma forma de expressá-las, tudo o que fazemos, seja em uma sala de aula, seja no cotidiano, é dividir nossas experiências, desejos e futuros, compartilhar justamente o que nos torna humanos, no sentido mais verdadeiro da palavra, que é o conhecimento [...] (grifo nosso) 
Verificamos que para este professor 15 , como para outros citados acima, a emoção faz parte do dia a dia na sala de aula e que está intimamente relacionada com a aprendizagem, mas ainda podemos observar que a razão é supervalorizada em relação à emoção. Quando o professor 15 nos diz que o que nos torna humanos é o conhecimento ele revela a importância dada ao conhecimento e, na nossa interpretação, consequentemente a razão.

O professor 05 enquanto conversávamos antes da aplicação do opiniário disse que "o grande problema da educação é que o aluno não quer aprender, ele é um doente que não quer receber a cura" Isto significa que o conhecimento é o protagonista da sala de aula e podemos acreditar que com isso a emoção e a linguagem são apenas coadjuvantes, muitas vezes deixadas de lado.

Percebemos que a afirmação 12 do opiniário, a que diz que "todas as explicações que um indivíduo dá sobre a realidade são válidas e legítimas, mesmo que os outros as considerem erradas" causou certa polêmica entre os professores e alguns expuseram sua visão sobre ela:

[...] Na questão 12: “ Todas as explicações que um indivíduo dá sobre a realidade são válidas e legítimas, mesmo que os outros as considerem erradas" - é preciso considerar o contexto em que elas são elaboradas, se não" tudo vale", cai-se no relativismo. Entendo que, principalmente no espaço da sala de aula, o professor precisa incentivar e valorizar diferentes formas de ver o mundo, mas considerando sempre o " contexto", ou como se diz nos estudos de linguagem "em que formação discursiva" se está falando[...] (prof. 30, grifo nosso)

[...] Na questão 12, quando afirma que "é valida e legítima", é válida e legítima para quê? Em que contexto devo considerar essa validade e legitimidade? No nível do indivíduo, certamente. No nível da sociedade, não. Caso contrário, por absurdo, teríamos que considerar legitima ideias homicidas, racistas, pedofílicas e coisas do gênero [...] (prof. 33, grifo nosso)

Quando Maturana (1997, p.24) diz que "tudo o que é dito é dito por um observador" ele quer dizer que cada um de nós tem uma visão de mundo, de acordo com a sua história de vida e com o seu sistema nervoso, entendido como um sistema fechado pelo autor. Desta forma toda explicação da experiência de um indivíduo é autêntica e legítima, portanto válida mesmo que não seja compartilhada por outra pessoa. Claro que a validade depende de um contexto, senão torna-se 
puro solipsismo ${ }^{1}$, e principalmente nas ciências onde a validação acontece através de um grupo de cientistas que aceitam a explicação.

O professor 33 concluiu que se for tudo válido, atitudes ou ideias como pedofilia, racismo e homicídios seriam válidas, o que seria um absurdo, mas devemos lembrar que a partir do momento que trabalhamos com a aceitação do outro como legítimo outro, tendo o amor como base biológica dos seres humanos e a colaboração entre os seres, permitindo assim a nossa evolução, essas ideias que excluem e negam o outro não seriam aceitas de maneira alguma, não fariam parte de nossa sociedade.

Gostaríamos de destacar a preocupação de alguns professores em responder o opiniário de maneira "certa" ou mesmo de se expor. O professor 21 quando nos entregou o opiniário preenchido disse "espero que você não me ache burrinha por ter respondido dessa maneira", a partir daí percebemos como há uma preocupação em agradar o pesquisador, em responder aquilo que o pesquisador quer ou precisa. Isto revela também a insegurança em ser avaliado por outro, uma vez que parece prevalecer a ideia que se avalia o ser dos indivíduos. Podemos inferir que provavelmente essas emoções de insegurança, ou de preocupação com a utilização de suas respostas os impeçam de dar sua opinião às questões escritas, pois verificamos que mais de $50 \%$ dos professores deixaram de respondê-las. A partir desta verificação nos perguntamos o quanto o sujeito da pesquisa é realmente sincero nas respostas em geral, sejam elas quantitativas ou qualitativas, pois ao responder as questões, as emoções estão sempre presentes.

Podemos verificar algumas passagens nos textos sobre essa preocupação:

[...] Tomara minhas respostas sejam úteis para você [...] (prof.05, grifo nosso)

[...] Talvez eu tenha que ler mais obras voltadas à educação. Com certeza teria respondido decentemente as três ultimas perguntas [...] (prof.23, grifo nosso)

Alguns professores manifestaram a dificuldade em aplicar as ideias de Maturana na sala de aula:

\footnotetext{
${ }^{1}$ Doutrina filosófica segundo a qual a única realidade no mundo é o eu. (Dicionário Novo Aurélio Século XXI)
} 
[...] Considero as ideias de Maturana muito difíceis de serem colocadas em prática em uma sociedade que é competitiva por excelência. $O$ próprio acesso à Universidade consiste em um processo exclusivo e não inclusivo. Nas escolas particulares, via de regra, não há espaço para proporcionar maior diálogo entre professor/alunos e nem para se estabelecer uma relação de convivência mais amorosa porque há uma corrida contínua contra o tempo para se conseguir cumprir o "planejamento".

Eu me pergunto como é possível conhecer o outro e reconhecer no outro se geralmente nem o nome da maioria dos alunos o professor consegue aprender porque eles são muitos e o tempo de convivência limita-se a menos de 3 horas por semana... [...] (prof. 20, grifo nosso)

Neste trecho da escrita do professor 20 é possível perceber as inquietações do professor principalmente quando ele diz que não há tempo para a convivência ou para um maior diálogo entre professor/aluno e que a sociedade é competitiva. O professor expõe a sua insatisfação com a sociedade competitiva, ao mesmo tempo em que se mostra paralisado frente a essa realidade. Ao atribuir à falta de tempo, como a razão de ser impossível se conhecer o outro, o professor parece se proteger e se eximir de sua própria responsabilidade no processo educativo. Diante da situação revelada no texto do professor 20 acreditamos que o conhecimento das ideias de Maturana seria de grande valor para que professores pudessem repensar seu papel e sua própria prática.

A partir dessas questões dissertativas emergiu a necessidade de continuarmos esta pesquisa através de grupos focais, o que poderá fazer parte de um trabalho posterior, como continuidade a este estudo exploratório. Esses grupos focais terão como objetivo a discussão dos temas mais relevantes que surgiram durante este trabalho.

Consideramos as ideias de Maturana de grande valor para as interações em sala de aula, com possibilidades de contribuir para o processo de ensino/aprendizagem, mas para que esse processo possa acontecer é necessário que todos da interação estejam de acordo, aceitando e respeitando mutuamente. Para isso uma discussão sobre o ensino/aprendizagem coinspirados se faz necessário. 


\subsection{A importância do Ensino/Aprendizagem Coinspirados}

Uma formiguinha atravessa, em diagonal, a página ainda em branco. Mas ele aquela noite, não escreveu nada. Para quê? Se por ali já haviam passado o frêmito e o mistério da vida...

Mário Quintana

Em sua Tese de Doutorado, Pizzato (2010) define ensino e aprendizagem coinspirados baseada na ideia de coinspiração de Maturana. A expressão coinspirado indica um processo colaborativo onde os indivíduos da interação descobrem o prazer de fazer coisas juntos em um clima de respeito mútuo.

Sabemos que as mudanças estruturais, que são espontâneas, podem ser desencadeadas pela interação entre o organismo e o meio, ou entre dois ou mais organismos, denominadas de acoplamento estrutural. O agente externo só desencadeia ou seleciona essas mudanças de estado, pois as mudanças estruturais só ocorrem se forem "permitidas" pela própria estrutura. Essas mudanças levam a uma adaptação do indivíduo, e este aspecto adaptativo pressupõe uma coletividade, pois estamos conectados historicamente.

Para Pizzato (2010) no ensino/aprendizagem coinspirados a aceitação de si mesmo e do outro, como também o respeito mútuo, permitem o compartilhamento do prazer em se fazer algo junto. A autora explica que as relações não são todas do mesmo tipo, pois dependem das emoções que as sustentam e, portanto, é necessário identificar as emoções que fazem parte da convivência. A aprendizagem é uma mudança estrutural espontânea e não podemos garantir que ela aconteça apenas podemos identificar a intenção do professor em provocar essas mudanças, guiando as interações por ser o indivíduo com mais experiência. Assim, o espaço psíquico do professor influencia o espaço de convivência. Este espaço de convivência é aquele em que há respeito e aceitação do outro e onde o aluno pode crescer como ser humano consciente e responsável.

O ensino coinspirado tem como pressuposto a ideia de objetividade entre parênteses de Maturana, onde a explicação depende do observador. Assim podemos entender que existem várias realidades explicativas para a mesma 
experiência ou fenômeno e o observador tem a liberdade de escolher o domínio de realidade que irá viver.

A autora considera como a emoção fundamental que orienta o ensino coerente a aceitação do outro como legítimo outro, aceitando assim as diversas explicações como legítimas e válidas, mesmo que não sejam as desejadas. Ela considera a igualdade de validade de domínios explicativos, onde o domínio explicativo do professor não é melhor que o do aluno, apesar de que inconscientemente professores negam essa igualdade. Ela propõe que professores precisam escutar as ideias dos alunos, aceitando-as como válidas dentro do domínio explicativo de cada um deles.

[...] O professor coinspirado atua como um guia, com um plano predeterminado sobre o caminho escolhido por ele, sendo como um companheiro de viagem que convide o estudante a conhecer outro domínio explicativo diferente, e o acompanha em um caminho que eles vão fazendo junto, mas com a diferença que o professor tem mais experiências em "viagens" [...] (Pizzato, 2010, p.315).

A aceitação das explicações gera um espaço de convivência onde surge a confiança e ao atuarmos na confiança as discussões das ideias ocorrem sem marginalizações e o "erro pode ser visto como uma oportunidade para aprender" (p.323).

Para a autora a presença ou não de confiança em si mesmo e no outro se desenvolve na convivência entre professores e alunos e a responsabilidade em desencadear essas noções é do professor.

Ainda para Pizzato (2010), a aprendizagem não depende do quanto o professor sabe sobre determinado conhecimento científico ou psicopedagógico e sim como ele lida com os critérios de validação em um espaço educacional desejado, associado às suas concepções epistemológicas, acadêmicas, pedagógicas e ontológicas.

A autora crê que o professor consciente busca propiciar espaços de convivências que permitam que seus alunos desenvolvam suas ideias e os critérios de validação próprios oferecendo "ferramentas que o ajudarão a tomar consciência de seu processo de aprendizagem" (p.335). E, se vivemos em coerências operacionais distintas, de acordo com a deriva estrutural de cada um, repetir o operar do professor não garantirá a experiência desejada pelo professor, pois esta 
surge com o operar próprio. O professor deve aproximar do domínio explicativo de seu aluno, para que a partir deste domínio, da compreensão que o aluno tem sobre um fenômeno, mostre o seu operar, e o aluno ao refletir e comparar experiências vividas com as concepções prévias poderá escolher conscientemente quais concepções quer conservar e quais serão mudadas.

Em sua Tese a autora explicita a importância em se enfatizar, nos processos formativos de professor, a percepção da dinâmica recursiva da conversação, onde a emoção e a linguagem se entrelaçam podendo gerar o raciocinar.

Professores e alunos são sistemas determinados estruturalmente, nada externo pode especificar o que acontece a eles, porém o professor é responsável e livre para escolher as vivências que proporcionará aos alunos em sala de aula.

O processo de ensino/aprendizagem coinspirado se opõe ao processo de ensino/aprendizagem coagido, da expressão coação, que parece prevalecer na relação pedagógica e na escola de uma maneira geral. O ensino/aprendizagem coagido, na nossa perspectiva é violentamente desumanizador e, como antagônico às relações coinspiradas, promove a competição e não a colaboração. Podemos assim expressar algumas considerações sobre a necessidade de relações coinspiradas uma vez que, como professores temos o papel de desencadear mudanças estruturais em nossos alunos, o que podemos chamar de aprendizagem, mas isso só é possível se houver uma predisposição emocional para aprendê-lo.

As interações em sala de aula devem ser fundamentadas no respeito mútuo, no aceitar o outro como legítimo outro, onde o outro não se sinta negado em suas dificuldades. Conduzir o emocionar do aluno como também criar estratégias diversas para desencadear mudanças estruturais de maneira mais ampla faz parte da função do professor, por ser ele o mais experiente da relação.

Quando o aluno dá uma explicação a um fenômeno ele o faz como um observador, fazendo distinções e descrições de acordo com suas experiências e seus conhecimentos, sempre através da linguagem. Assim, acreditamos que é necessário que professor conheça e reflita sobre a objetividade entre parênteses, uma vez que ao conhecê-la poderá tomar decisões e promover transformações na sala de aula. Nesta perspectiva onde todas as explicações são válidas e legítimas, de acordo com a história de cada um, se gera o diálogo e a aceitação do outro. 
Porém, infelizmente não é o que vemos normalmente em uma sala de aula, pois ainda se procura pela "resposta certa" e pela verdade absoluta das ciências, e quando o aluno não se encontra nesta verdade o erro se destaca e a frustração por não "dizer ou fazer a coisa certa" se instala neste aluno. Ele será negado e deixará de refletir e expor suas opiniões sobre os temas, ou sobre o mundo.

Somos seres únicos e diferentes, influenciados a cada instante pelas emoções que determinam nossas condutas e com ela o nosso explicar, portanto as diferenças nos domínios explicativos são inevitáveis dentro e fora de uma sala de aula.

A submissão não tem sentido na objetividade entre parênteses, e o professor ao criar um clima emocional favorável às interações, de tranquilidade e confiança, permite que seus alunos se expressem dentro de seus próprios critérios de validação, proporciona um ambiente em que todos, ou pelo menos a maioria, se manifestem. As discrepâncias nas respostas, que chamamos de erros, poderão ser oportunidades de discutir, desalojar, refletir até que uma explicação melhor, mais amplamente coerente e aceita seja encontrada. O professor deve promover o ensino baseado na interação social, que só o amor permite, para que a observação, a discussão e a reflexão façam parte do fazer em sala de aula.

Percebemos também a importância em explicitar que o processo de avaliação na sala de aula se refere ao fazer do aluno e não ao seu ser, pois o que percebemos no dia a dia, assim como durante a aplicação de nossa pesquisa, foi que a avaliação é entendida, mesmo que inconscientemente, como de cunho pessoal, o que torna o processo avaliativo um desencadeador de emoções negativas como insegurança e medo. 


\title{
6. Considerações finais
}

\author{
Para ser grande, sê inteiro: nada \\ Teu exagera ou exclui. \\ Sê todo em cada coisa. Põe quanto és \\ No minimo que fazes. \\ Assim em cada lago a lua toda \\ Brilha, porque alta vive. \\ Fernando Pessoa (Ricardo Reis)
}

Esta pesquisa teve como ponto de partida as inquietações e angustias da própria pesquisadora como professora em exercício. As dificuldades do dia a dia, bem como a necessidade de se "desalojar" de sua passividade motivaram a busca de novos caminhos. Estes 20 anos de experiência em sala de aula permitiram a pesquisadora uma visão mais ampla de todo o caminho percorrido e a necessidade urgente de mudanças.

$\mathrm{Na}$ experiência escolar parece que o tempo cristaliza nos professores certa acomodação, o que gera desânimo e a falta de crença na educação e consequentemente na possibilidade de genuína mudança ou transformação da difícil realidade. Para nós, isso fica explícito em uma conversa que tivemos com o professor 42 durante a aplicação do opiniário. Ao finalizar a tarefa de responder, ele diz: "você acredita mesmo nisso? Na educação?". Essa descrença no processo educacional, nas novas gerações de alunos e na possibilidade de ter um trabalho digno, paralisa, cristaliza as insatisfações e destrói qualquer força de vontade em relação à mudança.

O professor por considerar que o sistema é assim, nada faz para mudar, se exime de toda e qualquer responsabilidade. Isto revela uma "malvadeza" nas palavras de Freire (Freire, 1996) do próprio sistema educacional, um problema maior e mais difícil de enfrentar, pois o que se revela nessa atitude do professor é apenas consequência dessa "malvadeza". A formação inicial do professor, a princípio, não Ihe permite ter autonomia, as regras são impostas, o conhecimento transmitido e suas opiniões nem sempre são ouvidas. Quando este ingressa em alguma escola, os colegas mais antigos interpretam as suas tentativas de mudanças como um lampejo ingênuo da juventude e a ideia de que nada pode ser feito contamina e engessa qualquer tentativa de mudança no professor iniciante. O professor que 
passa a ser determinado por este sistema se torna um técnico, um orientador de "caderninhos" e deixa de expor as suas ideias (Giroux, 1997), o professor não tem voz. Este profissional não percebe a sua importância, seu valor, dentro deste sistema educacional. O professor não se manifesta porque não se assume como intelectual atuante, capaz de transformar aquilo que o incomoda, ele é desvalorizado em sua função, mal remunerado e desrespeitado. A classe profissional de professores em geral não se une para discutir teorias pedagógicas, currículos, pleitear direitos ou gerar mudanças.

É de extrema importância que cada uma das esferas que participam do sistema educacional como a social, política, escolar e principalmente a esfera familiar, ocupem seu lugar com direitos e deveres. A família precisa voltar a ser a base da educação da criança, permitindo que esta entre em contato desde cedo com a ética primária, onde o respeito ao outro seja condição sine qua non de convivência em casa e também fora dela, permitindo assim as interações e mudanças. Não se trata aqui de fazer acusações em relação às ausências e/ou omissões de cada uma destas esferas, não é o objetivo deste trabalho, mas apenas estimular a reflexão ao fazer uma tentativa de diagnóstico da situação educacional.

Notamos que em relação ao professor, enquanto este não recupere a sua própria dignidade como profissional, respeitado antes de tudo como um ser humano e também como aquele que conduz o processo ensino/aprendizagem, dificilmente haverá mudanças. E o que percebemos é que a falta de esperança em relação à educação já se instala desde a formação do professor, pois este tende a reproduzir o exemplo que teve na formação superior, como também durante todo seu período escolar. Sabemos que parte dos problemas da educação é de cunho social, político, econômico e por que não dizer ético, e, portanto os professores partem do princípio de que nada pode ser feito para mudar essa realidade.

Os problemas da educação estão nas mãos de várias instâncias, inclusive da própria família da criança, mas como professores temos a obrigação e a capacidade de melhorar o que está diretamente relacionado com a nossa função: a relação pedagógica. Foi pensando nisso que surgiu a pergunta inicial de nossa pesquisa, como podemos dentro de uma sala de aula, através de interações entre professores e alunos gerar transformações que possam gerar conhecimento. 
Tudo isso nos leva a acreditar mais e mais que as ideias de Maturana poderiam fazer a diferença na reflexão do professor, como também em sua prática. Trabalhar suas concepções epistemológicas durante a formação inicial do professor e também em cursos de formação continuada poderia favorecer o surgimento de novas reflexões e práticas pedagógicas. A leitura das obras de Humberto Maturana abriu uma nova visão sobre esta relação pedagógica. Quando o autor parte de uma visão biológica do conhecimento, associando a importância das interações humanas e do acoplamento estrutural gerando mudanças, desde que estas sejam previstas pela própria estrutura do organismo, ele coloca em xeque a transmissão de conhecimento, ainda muito valorizada e utilizada entre os professores.

É claro que o conteúdo deve ser exposto pelo professor durante a sua aula, mas é importante destacar que apenas a exposição não garante a aprendizagem, nessa situação, em que apenas o professor tem voz, poderá ocorrer aprendizagem mecânica, isto é, a memorização com conteúdos que não fazem sentido para o estudante. É necessário que além do professor expor os conteúdos este favoreça o diálogo e a interação com seus alunos. Independente do acesso a recursos didáticos mais sofisticados como laboratórios equipados, computadores entre outros, para que ocorra o diálogo e a interação só se precisa de seres humanos. As interações, a convivência humana, bem como o espaço de formação são permeados pelas emoções e pela linguagem, essenciais para as transformações nos integrantes da interação, podendo assim gerar conhecimento.

Como professores deveríamos nos permitir a experiência da interação professor/aluno, ser capazes de nos abrir para os estímulos da relação humana, como indica Maroni (2008), mas o que observamos no dia a dia em sala de aula são apenas vivências, onde a as interações são racionalizadas, fechadas aos estímulos, assim se "livra do contato com a diferença que os verdadeiros encontros propiciam" (Maroni, 2008). A autora diferencia estes dois conceitos a experiência e a vivência, de acordo com as ideias de Walter Benjamim. Nestes tempos modernos, devido a traumas e choques, a consciência se fecha a estímulos, racionaliza-se e desta forma surge uma vivência, já a experiência por ser aberta a estímulos e aos sentidos aciona as memórias mais profundas e esquecidas e como a autora propõe "a experiência exige metáforas, simbolização e narração; as vivências não” (p.56). A experiência demanda tempo, que para a autora é importante para o resgate das 
memórias e para se fazer experiência é necessário conviver com a falta, com a frustração e a ausência. Maroni acredita que as pessoas fogem das experiências porque esta é indigesta, perturbadora. "Não fazemos experiência só com a razão, com o intelecto!" (p.58) é necessário se entregar a ela, cultivando novas atitudes e todas as formas de consciência. Nesta perspectiva a experiência envolve razão, emoção e linguagem.

Para a autora quando se trata de vivências fica apenas a certeza de se cumprir o papel social do professor, o que o protege da experiência. O professor mantém a idéia de que sua função é somente a transmissão de conhecimento, portanto ao chegar à escola, explicar a matéria, trabalhar exercícios e cobrá-los mais tarde em uma avaliação dão-lhe a sensação de trabalho realizado e seu papel social cumprido. Essa máscara social é uma máscara coletiva que determina a função profissional do professor e o impede de viver experiências. Durante a sua atividade pedagógica só a vivência faz parte da interação em sala de aula, pois essa máscara só Ihe permite ver o aluno como uma tabula rasa para onde o conhecimento será transferido.

Precisamos dar sentido às nossas experiências, cultivando novas atitudes o que permitirá verdadeiras transformações.

Como Maroni (2008) afirma:

[...] abrir-se para a experiência requer, como primeiro passo, desapegar-se do papel social, da máscara social. Esse papel social [...] oculta o que, de fato, interessa na aprendizagem: um lugar psíquico disponível [...] (p. 62)

A autora propõe que a experiência seja o novo solo psíquico onde possam surgir reflexões e que a sala de aula se transforme em um "lugar psíquico disponível", pois é um local rico para que experiências aconteçam. Quando o professor permite e favorece experiências, ele se transforma em um lugar psíquico para seus alunos, o guia dessa experiência, e é neste momento que surge a sua autoridade de professor. Desta forma quando as interações acontecem professor e alunos se tornam coensinantes.

É papel do professor permitir que a sala de aula seja um lugar de convivência, de interações, ao guiar o clima emocional do grupo, respeitando, ensinando e aprendendo. E é esse espaço psíquico que permitirá a aprendizagem 
de todos os sujeitos que participam da interação. Como adultos, os professores guiam seus alunos, com respeito mútuo, confiança e amor a se "transformarem em pessoas que respeitam a si mesmos sem medo de desaparecer na colaboração" (Maturana, 2010, p.33). Pois é na colaboração com o outro e no uso de sua autonomia como indivíduo que o aluno se expõe, cria, discorda, produz e se transforma. Para tanto é de extrema importância que se respeite o outro como um legítimo outro, deixando de lado as "certezas absolutas", tão comuns na percepção dos professores, em particular nos professores de ciências. Que na relação de ensino/aprendizagem, que fundamentalmente é uma relação entre seres humanos se permita emergir as diversas explicações dos fenômenos, sem censuras, sem sofrimentos, apenas explicações legítimas e válidas. E juntos, professores e alunos, num movimento de explicações, argumentações, reflexões, desencadeamentos de ações, retomadas de consciência e muito diálogo cheguem a uma explicação válida para todos.

Esse processo, aparentemente utópico, só é possível em um ambiente onde a confiança e o respeito estejam presentes, pois senão o que encontraremos na sala de aula serão indivíduos frustrados e negados em sua individualidade e autonomia. Utilizamos intencionalmente o termo utópico, pois no senso comum esta expressão geralmente se vincula a um sonho impossível, a uma realidade inatingível, mas para nós a expressão utopia tem o sentido atribuído por Paulo Freire, de esperança de mudança e de possibilidade de transformação. Esta perspectiva da utopia freireana junto à ideia de que o homem é um ser inacabado (Freire, 1996), nos permitem continuar acreditando que as transformações na educação são possíveis.

Finalmente podemos afirmar que a Biologia do Conhecer de Humberto Maturana além de constituir uma concepção epistemológica absolutamente original, tem o valor de ser uma tentativa explicativa coerente e inteligente, não um modelo. $A$ proposta de Maturana tem um caráter não positivista quanto a sua concepção de Ciência e um caráter humanista na sua concepção de educação com desafiadoras consequências éticas para todos aqueles que desejamos pensar a educação sob uma nova perspectiva. 


\section{Referências Bibliográficas}

ACEVEDO, J.A.; ACEVEDO, P. Creencias sobre la naturaleza de la ciencia. Um studio com titulados universitarios em formación inicial para ser profesores de Educación Secundaria. Revista Iberoamericana de Educación, Edición digital, 2002.

ACEVEDO, J.A. Formación del profesorado de Ciências y Enseñanza de la Naturaleza de La Ciência. Revista Eureka sobre Enseñanza y Divulgación de las Ciencias, v.7, n.3, p.653-660, 2010.

ADÚRIZ-BRAVO, A. Integración de la epistemologia em la formación del professorado de ciências. Tesis doctoral. Universitat Autònoma de Barcelona, 2001.

ALMEIDA, A.R.S. A emoção na sala de aula. Campinas: Papirus, 1999.

ARANTES, V.M.. Afetividade e Cognição: Rompendo a dicotomia na educação. In OLIVEIRA, M.K.; TRENTO, D.; REGO, T. Psicologia, educação e as temáticas da vida contemporânea. São Paulo: Ed. Moderna, 2002.

AZNAR, M.M.M.; DEL POZO, R.M.; VEGA, M.R. VARELA-NIETO, M.P.; LOZANO, M.P.F.; SERÓN, A.G. ¿Qué pensamiento profesional y curricular tienen los futuros profesores de ciências de secundaria? Enseñanza de las Ciencias, v.19, n.1, p. 67-87, 2001.

BAUMAN, Z. Modernidade e Ambivalência. Rio de Janeiro: Jorge Zahar, 1999.

BITTENCOURT, J. Para além da epistemologia do professor. Educação e Filosofia, v.15, n.30, p. 89-102, 2001.

BONITO, J. Concepções epistemológicas de alunos e professores: Um estudo no âmbito da didáctica. IX Congreso Internacional Galego-Portugués de Psicopedagoxía. Coord. por Alfonso Barca Lozano, Manuel Peralbo Uzquiano, Ana María Porto Rioboo, Bento Duarte da Silva, L. Almeida, 2008.

BUBER, M. Eu e tu. São Paulo: Centauro, 2001.

CHALMERS, A.F. O que é ciência afinal? São Paulo: Brasiliense, 1993.

DAMASIO, A. O Erro de Descartes: emoção, razão e o cérebro humano. São Paulo: Companhia da Letras, 1996.

FERRAZ, D.F.; OLIVEIRA, J.M.P. As concepções de professores de ciências e biologia sobre a natureza da ciência e sua relação com a orientação didática desses profissionais. Revista Varia Scientia, v.06, n.12, p. 85-106, 2006.

FREIRE, P. Pedagogia da autonomia: saberes necessários à prática educativa. São Paulo: Paz e Terra, 1996.

GIROUX, H.A. Os professores como intelectuais: rumo a uma pedagogia crítica da aprendizagem. Porto Alegre: Artes Médicas, 1997.

HARRES, J.B.S. Uma revisão de pesquisas nas concepções de professores sobre a natureza da ciência e suas implicações para o ensino. Investigações em Ensino de Ciências, Porto Alegre, v. 4, n. 3, p. 197-211, 1999. 
INFANTE-MALACHIAS, M.E.; CORREIA, P.R.M. Elaboración colaborativa de mapas de conceptos. Noveda des Educativas, n.219, p.72-76, 2009.

KOULADIS, V.; OGBORN, J. Philosophy of science: an empirical study of teachers' views. International Journal of Science Education, 11:2, 173-184, 1989.

LA TAILLE, Y.; OLIVEIRA, M.K.; DANTAS, H. Piaget, Vygotsky, Wallon: teorias psicogenéticas em discussão. São Paulo: Summus, 1992.

MARONI, A.M. E por que não?: Tecendo outras possibilidades interpretativas. Aparecida, SP: Idéias \& Letras, 2008.

MATURANA, H.R. MAGRO, C.; GRACIANO, M.; VAZ, N. A Ontologia da Realidade. Belo Horizonte: Ed. UFMG, 1997 a.

MATURANA, H.R. Emociones y lenguaje eneducación y política. DolmenEdiciones, Santiago de Chile, 1997b.

MATURANA, H.R.; VARELA, F.J. A árvore do conhecimento: as bases biológicas da compreensão humana. São Paulo: Palas Athena, 2001.

MATURANA, H.R. Cognição, ciência e vida cotidiana. MAGRO, C.; PAREDES, V. (org.). Belo Horizonte Ed. UFMG, 2001 b.

MATURANA, H.R. Autopoiesis, structural, coupling and cognition: a history of these and other notions in biology of cognition. Cybernetics \& Human Knowing, vol.9, $n \div$ - 3-4, p.5-34, 2002.

MATURANA, H.R.; YÁÑEZ, X.D. Habitar humano em seis ensaios de biologia-cultural. São Paulo: Palas Athena, 2009 a

MATURANA, H.R.; YÁÑEZ, X.D. Hacia uma era posmoderna em las comunidades educativas. Revista Iberoamericana de Educación, n.49, janeiro-abril de 2009.

MATURANA, H.R.; YÁÑEZ, X.D. El desamar: tentacion de la omnipotência y lacertidumbre. Memorial del Congresso Internacional de violência intrafamiliar. Chile. p. 123-126, 2010a.

MATURANA, H.R.; YÁÑEZ, X.D. Biologia del conocer y Biologia del amar: desde la matriz biológica de la existência humana. Revista Prelac, Chile, p. 31-39, 2010b.

MELLADO, V. ¿Por qué a los profesores de ciências nos cuesta tanto cambiar nuestras concepciones y modelos didácticos? Revista Interuniversitaria de Formación del Profesorado, n. 40, p. 17-30, 2001.

MELLADO, V. Cambio didáctico del professorado de ciências experimentales y filosofía de la ciência. Enseñanza de las Ciencias, 2003, n.21 (3), p.343-358, 2003.

MÉNDEZ, J.E.G.. Emoção como fundamento das interações humanas: um estudo a partir das obras de Humberto Maturana. Dissertação de mestrado. Universidade Católica de São Paulo, 1993.

MORAES, R. Uma tempestade de luz: A compreensão possibilitada pela análise textual discursiva. Ciência \& Educação, v. 9, no2, p. 191-211, 2003.

MOREIRA, M.A. Teorias de aprendizagem. São Paulo: EPU, 1999. 
MOREIRA, M.A. A epistemologia de Maturana. Ciência e Educação, v.10, n.3, p.597-606, 2004.

MORIN, E.. Os sete saberes necessários à educação do futuro. São Paulo: Cortez; Brasília, DF: UNESCO, 2003.

OLIVEIRA, A.C. A crítica de Carnap aos enunciados da metafísica. Revista Urutágua, n.18, maio-agosto. Maringá, p.29-36, 2009.

OLIVEIRA, M.M. Como fazer pesquisa qualitativa. Petrópolis, RJ: Editora Vozes, 2007.

PÁDUA, E.M.M. Metodologia da pesquisa: Abordagem teórico-prática. Campinas, SP: Papirus, 2004.

PELLANDA, N.M.C. Maturana \& a Educação. Belo Horizonte: Autêntica Editora Coleção Pensadores \& Educação, 2009.

PIAGET, J. Inteligencia y afectividad / con prólogo de: Mario Carretero $-1^{\text {a }}$ ed. $1^{\underline{a}}$ reimp. - Buenos Aires : Aique Grupo Editor, 2005.

PIZZATO, M.C. Enseñanza coinspirada: um estúdio de caso em la formación de professores de ciencias. Tesis doctoral. Universidad de Burgos, 2010.

POPE, M.L.; SCOTT, E.M. Personal experience and the construction of knowledge in science. Science Education, v.67, n.2, p. 193-203, 1983.

PORLÁN, A. Las creencias pedagógicas y científicas de los professores. Enseñanza de las Ciencias de la Tierra, (3. I), p.7-13, 1995.

PORLÁN, A.; RIVERO, G.A.; DEL POZO, R.M. Conocimiento profesional y epistemologia de los profesores, II: Estudios empíricos y conclusiones. Enseñanza de lasCiencias, v.16, n.2, p. 271-288, 1998.

PORLÁN, A, DEL POZO R.M. El conocimiento del profesorado sobre la ciência, su enseñanza y aprendizaje. In F.J. Perales e P. Cañal (disc.). Didáctica de las ciências experimentales. Alcoy: Marfil, p.507-533, 2000.

PORLÁN, A. DEL POZO R.M. The conceptions of in-service and prospective primary schoolteachers about the teaching and learning of science. Journal of Science Teacher Education, 15(1), p. 39-62, 2004.

PRAIA, J.; CACHAPUZ, F. Um análisis de las concepciones acerca de la naturaliza del conocimiento cientifico de los profesores portugueses de la enseñanza secundaria.Enseñanza de las Ciencias, 12 (3), p.350-354, 1994.

PRAWAT, R.S. Teacher's beliefs about teaching and learning: a construtivist perspective. American JournalofEducation, May 1992, p. 354-395. 1992.

RAMPAZZO, L. Metodologia científica para alunos de graduação e pós-graduação. Ed. Stiliano, Lorena-SP. 152p, 1998.

RAVANAL, E. ; QUINTANILLA, M. Caracterización de las concepciones epistemológicas del profesorado de biologia em ejercicio sobre la naturaleza de la ciencia. Enseñanza de las Ciencias, v.9, n.1, p. 111-124, 2010. 
ROSA. C. T. W. ; ROSA, A. B. Discutindo as concepções epistemológicas a partir da metodologia utilizada no laboratório didático de física. Revista lberoamericana de Educación, n.52/6, maio/2010.

SANTOS, F.M.T. As emoções nas interações e a aprendizagem significativa. Ensaio Pesquisa em Educação em Ciências, v.9, n.2, 2007.

SPENCER, R.; De BARROS, M. Razão e Racionalidade: Ensaios de Filosofia. São Paulo, T.A. Queiroz, Editor. 316p, 1993.

TASSONI,E.C.M. A afetividade e aprendizagem: a relação professor-aluno. In: Psicologia, análise e crítica da prática educacional. Campinas: ANPED, 2000.

TEIXEIRA,R.J.D.; MELACO, G.A. Empirismo lógico do círculo de Viena e falsificacionismo de Karl Popper. Caderno Brasileiro de Física, 2010.

VÁZQUEZ, B.; JIMÉNEZ, R.; MELLADO, V. El desarrollo professional del profesorado de ciências como integración de la práctica. La hipótesis de la complejidad. Revista Eureka sobre Enseñanza y divulgación de las Ciencias v.4,n.3, p. 372-393, 2007.

VIEIRA, A.J.H. Humberto Maturana e o espaço relacional da construção do conhecimento. Humanitates. Centro de Ciências de educação e Humanidade. Universidade Católica de Brasília. Vol. I, n. 2, 2004.

VYGOTSKY, L.S. A construção do pensamento e da linguagem. São Paulo : Martins Fontes, 2000.

WIESER, W. Organismos, estruturas, máquinas: para uma teoria do organismo. Tradução de Amélia Cohn. São Paulo: Cultrix, 1972.

ZEMBYLAS, M. Young children's emotional practices while engaged. In: long-term science investigation. Journal of Research in Science Teaching vol. 41, no. 7, pp. 693-719, 2004. 


\section{APÊNDICES E ANEXOS}

\section{APÊNDICE 1 - Tabela4-Questionário do tipo Likert aplicado como pré- teste}

\begin{tabular}{|c|c|c|c|c|c|c|}
\hline 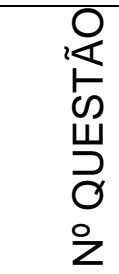 & FRASES & 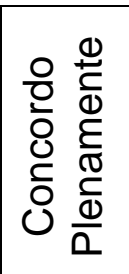 & 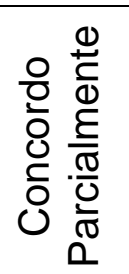 & 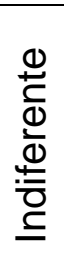 & 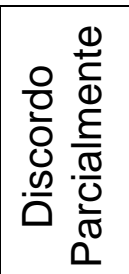 & 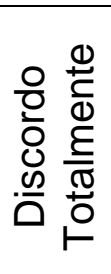 \\
\hline 1 & $\begin{array}{l}\text { Como seres humanos temos, } \\
\text { como diretriz de nossos atos, a } \\
\text { razão. }\end{array}$ & & & & & \\
\hline 2 & $\begin{array}{l}\text { A emoção é um obstáculo ao } \\
\text { pensamento racional. }\end{array}$ & & & & & \\
\hline 3 & $\begin{array}{l}\text { Os aspectos cognitivos da } \\
\text { aprendizagem tem um valor maior } \\
\text { em relação aos aspectos } \\
\text { emocionais. }\end{array}$ & & & & & \\
\hline 4 & $\begin{array}{l}\text { A emoção é importante para a } \\
\text { aprendizagem, pois está } \\
\text { associada à tomada de decisões. }\end{array}$ & & & & & \\
\hline 5 & $\begin{array}{l}\text { O aluno que possui uma relação } \\
\text { conflituosa em casa pode } \\
\text { aprender qualquer assunto, desde } \\
\text { que consiga prestar atenção à } \\
\text { explicação do professor. }\end{array}$ & & & & & \\
\hline 6 & $\begin{array}{l}\text { Um dos papéis do professor é } \\
\text { identificar as emoções que } \\
\text { desencadeiam as condutas dos } \\
\text { alunos em sala de aula. }\end{array}$ & & & & & \\
\hline 7 & $\begin{array}{l}\text { O professor como indivíduo que } \\
\text { detém o saber científico, tem } \\
\text { como dever transmiti-lo a seus } \\
\text { alunos. }\end{array}$ & & & & & \\
\hline 8 & $\begin{array}{l}\text { Para que o conhecimento seja } \\
\text { transmitido é necessário a } \\
\text { atenção total por parte dos alunos. }\end{array}$ & & & & & \\
\hline 9 & $\begin{array}{l}\text { Temos que abrir espaço para } \\
\text { discussão em sala de aula, onde } \\
\text { as concepções ingênuas dos } \\
\text { alunos façam parte dela. }\end{array}$ & & & & & \\
\hline
\end{tabular}

Tabela 4: A primeira coluna é o número da questão, a segunda coluna a frase e demais colunas as expressões de concordância ou não. 
Continuação da Tabela 4

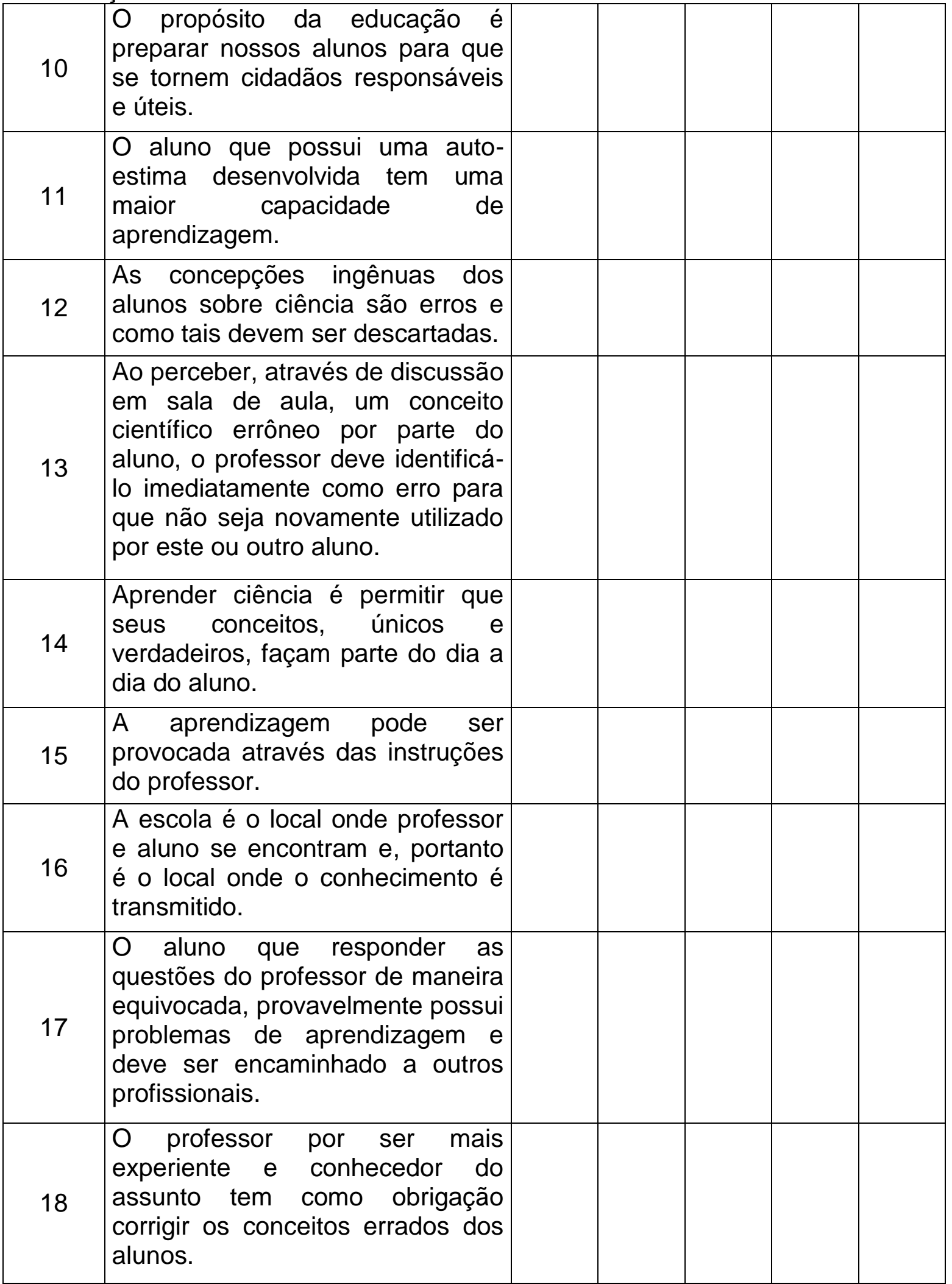

Tabela 4: A primeira coluna é o número da questão, a segunda coluna a frase e demais colunas as expressões de concordância ou não. 
Continuação da Tabela 4

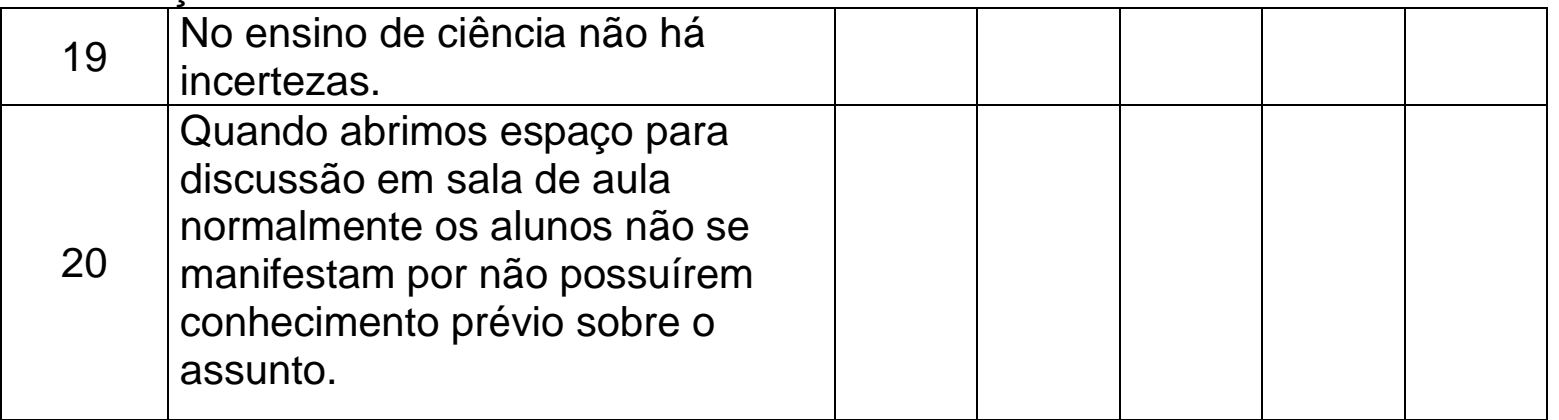

Tabela 4: A primeira coluna é o número da questão, a segunda coluna a frase e demais colunas as expressões de concordância ou não. 


\section{APÊNDICE 2. Tabela 5-Questionário de notas aplicado aos professores de ciências}

\begin{tabular}{|c|c|c|}
\hline $\begin{array}{l}\text { Número da } \\
\text { Questão }\end{array}$ & FRASES & NOTAS \\
\hline 1 & $\begin{array}{l}\text { Como seres humanos, temos como diretriz de } \\
\text { nossos atos a razão. }\end{array}$ & \\
\hline 2 & $\begin{array}{l}\text { Os aspectos cognitivos da aprendizagem tem um } \\
\text { valor maior em relação aos aspectos emocionais. }\end{array}$ & \\
\hline 3 & $\begin{array}{l}\text { O aluno aprende quando presta atenção no } \\
\text { professor. }\end{array}$ & \\
\hline 4 & $\begin{array}{l}\text { O professor é o indivíduo que detêm o saber } \\
\text { científico. }\end{array}$ & \\
\hline 5 & $\begin{array}{l}\text { Para que o conhecimento seja transmitido é } \\
\text { necessária a atenção total por parte dos alunos. }\end{array}$ & \\
\hline 6 & $\begin{array}{l}\text { O propósito da educação é preparar nossos alunos } \\
\text { para que se tornem cidadãos responsáveis e úteis à } \\
\text { sociedade. }\end{array}$ & \\
\hline 7 & $\begin{array}{l}\text { O professor tem como dever transmitir seus } \\
\text { conhecimentos aos seus alunos. }\end{array}$ & \\
\hline 8 & $\begin{array}{l}\text { As concepções ingênuas ou cotidianas dos alunos } \\
\text { sobre ciência em geral são erradas. }\end{array}$ & \\
\hline 9 & $\begin{array}{l}\text { As concepções ingênuas ou cotidianas devem fazer } \\
\text { parte das discussões em sala de aula. }\end{array}$ & \\
\hline 10 & $\begin{array}{l}\text { As concepções ingênuas ou cotidianas dos alunos } \\
\text { devem ser descartadas. }\end{array}$ & \\
\hline 11 & $\begin{array}{l}\text { O professor deve identificar um conceito errôneo } \\
\text { para que não seja novamente utilizado por este ou } \\
\text { outro aluno. }\end{array}$ & \\
\hline 12 & $\begin{array}{l}\text { O aluno que responder as questões do professor de } \\
\text { maneira equivocada, provavelmente possui } \\
\text { problemas de aprendizagem e deve ser } \\
\text { encaminhado a outros profissionais. }\end{array}$ & \\
\hline 13 & $\begin{array}{l}\text { O professor por ser mais experiente e conhecedor } \\
\text { do assunto tem como obrigação corrigir os } \\
\text { conceitos errados dos alunos. }\end{array}$ & \\
\hline
\end{tabular}

Tabela 5. Questionário de notas onde a primeira coluna indica o ํㅜ da questão, na segunda coluna a afirmação e na última coluna a nota atribuída pelo professor. 
Continuação Tabela 5

\begin{tabular}{|c|c|}
\hline 14 & $\begin{array}{l}\text { Aprender ciência é permitir que seus conceitos } \\
\text { façam parte do dia a dia do aluno. }\end{array}$ \\
\hline 15 & $\begin{array}{l}\text { Ciência é formada por conceitos únicos e } \\
\text { verdadeiros. }\end{array}$ \\
\hline 16 & Na Ciência não há incertezas. \\
\hline 17 & No ensino de ciência não há incertezas. \\
\hline 18 & $\begin{array}{l}\text { Aprender ciência é permitir que seus conceitos } \\
\text { sejam fonte de cultura e reflexão para o aluno. }\end{array}$ \\
\hline 19 & A ciência possui conceitos testáveis e transitórios. \\
\hline 20 & A emoção está associada à tomada de decisões. \\
\hline 21 & A emoção é um obstáculo ao pensamento racional. \\
\hline 22 & A emoção é importante para a aprendizagem. \\
\hline 23 & $\begin{array}{l}\text { O aluno que possui uma auto-estima desenvolvida } \\
\text { tem uma maior capacidade de aprendizagem. }\end{array}$ \\
\hline 24 & $\begin{array}{l}\text { O aluno que possui uma relação conflitiva na família } \\
\text { pode aprender qualquer assunto. }\end{array}$ \\
\hline 25 & A emoção fundamental do ser humano é o amor. \\
\hline 26 & $\begin{array}{l}\text { Um dos papéis do professor é identificar as } \\
\text { emoções dos alunos em sala de aula. }\end{array}$ \\
\hline 27 & $\begin{array}{l}\text { O amor pode modificar a relação tríadica } \\
\text { professor/aluno/conhecimento. }\end{array}$ \\
\hline 28 & $\begin{array}{l}\text { Quando abrimos espaço para discussão em sala de } \\
\text { aula normalmente os alunos não se manifestam. }\end{array}$ \\
\hline 29 & $\begin{array}{l}\text { É preciso abrir espaços para discussões em sala de } \\
\text { aula. }\end{array}$ \\
\hline
\end{tabular}

Tabela 5. Questionário de notas onde a primeira coluna indica o no da questão, na segunda coluna a afirmação e na última coluna a nota atribuída pelo professor. 
Continuação Tabela 5

\begin{tabular}{|c|c|}
\hline 30 & $\begin{array}{l}\text { Normalmente os alunos não se manifestam nas } \\
\text { discussões em aula por que não abrimos espaço } \\
\text { para eles. }\end{array}$ \\
\hline 31 & $\begin{array}{l}\text { Os alunos não possuem conhecimento prévio sobre } \\
\text { os assuntos abordados. }\end{array}$ \\
\hline 32 & $\begin{array}{l}\text { A aprendizagem pode ser provocada através das } \\
\text { intervenções do professor. }\end{array}$ \\
\hline 33 & $\begin{array}{l}\text { A escola é o local onde professor e aluno se } \\
\text { encontram e, portanto é o local onde o } \\
\text { conhecimento é transmitido. }\end{array}$ \\
\hline 34 & $\begin{array}{l}\text { A linguagem e a cognição estão constantemente se } \\
\text { constituindo socialmente. }\end{array}$ \\
\hline 35 & $\begin{array}{l}\text { A educação é um processo no qual alunos e } \\
\text { professores se transformam enquanto interagem. }\end{array}$ \\
\hline 36 & O ser humano se constitui na linguagem. \\
\hline 37 & $\begin{array}{l}\text { O espaço educacional é um espaço de ampliação da } \\
\text { inteligência. }\end{array}$ \\
\hline 38 & $\begin{array}{l}\text { A avaliação deve ser feita sobre o fazer do } \\
\text { estudante e não sobre seu ser. }\end{array}$ \\
\hline
\end{tabular}

Tabela 5. Questionário de notas onde a primeira coluna indica o ํㅜ da questão, na segunda coluna a afirmação e na última coluna a nota atribuída pelo professor. 


\section{APÊNDICE 3- Tabela6- Questões aplicadas aos professores e as categorias teóricas a que pertencem}

\begin{tabular}{|c|c|c|}
\hline & Frases & Categorias Teóricas \\
\hline 1 & $\begin{array}{l}\text { Como seres humanos temos como diretriz } \\
\text { de nossos atos a razão. }\end{array}$ & I \\
\hline 2 & $\begin{array}{l}\text { Os aspectos cognitivos da aprendizagem } \\
\text { tem um valor maior em relação aos } \\
\text { aspectos emocionais. }\end{array}$ & I \\
\hline 3 & $\begin{array}{l}\text { O aluno aprende quando presta atenção no } \\
\text { professor. }\end{array}$ & I \\
\hline 4 & $\begin{array}{l}\text { O professor é o indivíduo que detêm o } \\
\text { saber científico. }\end{array}$ & I \\
\hline 5 & $\begin{array}{l}\text { Para que o conhecimento seja transmitido é } \\
\text { necessário a atenção total por parte dos } \\
\text { alunos. }\end{array}$ & I \\
\hline 6 & $\begin{array}{l}\text { O propósito da educação é preparar nossos } \\
\text { alunos para que se tornem cidadãos } \\
\text { responsáveis e úteis à sociedade. }\end{array}$ & I \\
\hline 7 & $\begin{array}{l}\text { O professor tem como dever transmitir seus } \\
\text { conhecimentos aos seus alunos. }\end{array}$ & I \\
\hline 8 & $\begin{array}{l}\text { As concepções ingênuas ou cotidianas dos } \\
\text { alunos sobre ciência em geral são erradas. }\end{array}$ & I \\
\hline 9 & $\begin{array}{l}\text { As concepções ingênuas ou cotidianas } \\
\text { devem fazer parte das discussões em sala } \\
\text { de aula. }\end{array}$ & II \\
\hline 10 & $\begin{array}{l}\text { As concepções ingênuas ou cotidianas dos } \\
\text { alunos devem ser descartadas. }\end{array}$ & I \\
\hline 11 & $\begin{array}{l}\text { O professor deve identificar um conceito } \\
\text { errôneo para que não seja novamente } \\
\text { utilizado por este ou outro aluno. }\end{array}$ & I \\
\hline
\end{tabular}

Tabela 6. Na primeira coluna o número da questão, na segunda coluna a questão ou afirmação e na última coluna a categoria teórica a que pertence. 
Continuação Tabela 6

\begin{tabular}{|c|c|c|}
\hline 12 & $\begin{array}{l}\text { O aluno que responder as questões do } \\
\text { professor de maneira equivocada, } \\
\text { provavelmente possui problemas de } \\
\text { aprendizagem e deve ser encaminhado a outros } \\
\text { profissionais. }\end{array}$ & I \\
\hline 13 & $\begin{array}{l}\text { O professor por ser mais experiente e } \\
\text { conhecedor do assunto tem como obrigação } \\
\text { corrigir os conceitos errados dos alunos. }\end{array}$ & I \\
\hline 14 & $\begin{array}{l}\text { Aprender ciência é permitir que seus conceitos } \\
\text { façam parte do dia a dia do aluno. }\end{array}$ & I \\
\hline 15 & $\begin{array}{l}\text { Ciência é formada por conceitos únicos e } \\
\text { verdadeiros. }\end{array}$ & I \\
\hline 16 & Na Ciência não há incertezas. & I \\
\hline 17 & No ensino de ciência não há incertezas. & I \\
\hline 18 & $\begin{array}{l}\text { Aprender ciência é permitir que seus conceitos } \\
\text { sejam fonte de cultura e reflexão para o aluno. }\end{array}$ & II \\
\hline 19 & $\begin{array}{l}\text { A ciência possui conceitos testáveis } \mathrm{e} \\
\text { transitórios. }\end{array}$ & II \\
\hline 20 & $\begin{array}{l}\text { A emoção está associada à tomada de } \\
\text { decisões. }\end{array}$ & II \\
\hline 21 & $\begin{array}{l}\text { A emoção é um obstáculo ao pensamento } \\
\text { racional. }\end{array}$ & I \\
\hline 22 & A emoção é importante para a aprendizagem. & II \\
\hline 23 & $\begin{array}{l}\text { O aluno que possui uma auto-estima } \\
\text { desenvolvida tem uma maior capacidade de } \\
\text { aprendizagem. }\end{array}$ & II \\
\hline 24 & $\begin{array}{l}\text { O aluno que possui uma relação conflitiva na } \\
\text { família pode aprender qualquer assunto. }\end{array}$ & II \\
\hline
\end{tabular}

Tabela 6. Na primeira coluna o número da questão, na segunda coluna a questão ou afirmação e na última coluna a categoria teórica a que pertence. 
Continuação Tabela 6

\begin{tabular}{|c|l|c|}
\hline 25 & $\begin{array}{l}\text { A emoção fundamental do ser humano é o } \\
\text { amor. }\end{array}$ & II \\
\hline 26 & $\begin{array}{l}\text { Um dos papéis do professor é identificar as } \\
\text { emoções dos alunos em sala de aula. }\end{array}$ & II \\
\hline 27 & $\begin{array}{l}\text { O amor pode modificar a relação triádica } \\
\text { professor/aluno/conhecimento. }\end{array}$ & II e III \\
\hline 28 & $\begin{array}{l}\text { Quando abrimos espaço para discussão } \\
\text { em sala de aula normalmente os alunos } \\
\text { não se manifestam. }\end{array}$ & III \\
\hline 29 & $\begin{array}{l}\text { É preciso abrir espaços para discussões } \\
\text { em sala de aula. }\end{array}$ & III \\
\hline 30 & $\begin{array}{l}\text { Normalmente os alunos não se manifestam } \\
\text { nas discussões em aula por que não } \\
\text { abrimos espaço para eles. }\end{array}$ & II e III \\
\hline 31 & $\begin{array}{l}\text { Os alunos não possuem conhecimento } \\
\text { prévio sobre os assuntos abordados. }\end{array}$ & I \\
\hline 32 & $\begin{array}{l}\text { A aprendizagem pode ser provocada } \\
\text { através das intervenções do professor. }\end{array}$ \\
\hline 33 & $\begin{array}{l}\text { A escola é o local onde professor e aluno } \\
\text { se encontram e, portanto é o local onde o } \\
\text { conhecimento é transmitido. }\end{array}$ \\
\hline 34 & $\begin{array}{l}\text { A linguagem e a cognição estão } \\
\text { constantemente se constituindo } \\
\text { socialmente. }\end{array}$ \\
\hline 35 & $\begin{array}{l}\text { A educação é um processo no qual alunos } \\
\text { e professores se transformam enquanto } \\
\text { interagem. }\end{array}$ \\
\hline 36 & $\begin{array}{l}\text { O ser humano se constitui na linguagem. } \\
\text { ampliação da inteligência. }\end{array}$ & II e III \\
\hline estudante e não sobre seu ser. \\
\hline $\begin{array}{l}\text { A avaliação deve ser feita sobre o fazer do } \\
\text { estall }\end{array}$
\end{tabular}

Tabela 6. Na primeira coluna o número da questão, na segunda coluna a questão ou afirmação e na última coluna a categoria teórica a que pertence. 
APÊNDICE 4- Tabela7. Tabulação das notas dadas pelos professores às perguntas do questionário.

\begin{tabular}{|c|c|c|c|c|c|c|c|c|c|c|}
\hline & 1 & 2 & 3 & 4 & 5 & 6 & 7 & 8 & 9 & 10 \\
\hline Q.1 & 2 & 2 & 0 & 0 & 7 & 2 & 6 & 5 & 2 & 2 \\
\hline Q.2 & 3 & 3 & 1 & 1 & 7 & 7 & 2 & 3 & 1 & 0 \\
\hline Q.3 & 4 & 2 & 2 & 0 & 3 & 5 & 6 & 5 & 1 & 0 \\
\hline Q.4 & 7 & 4 & 0 & 1 & 3 & 1 & 4 & 4 & 1 & 3 \\
\hline Q.5 & 2 & 1 & 2 & 0 & 8 & 6 & 2 & 2 & 1 & 4 \\
\hline Q.6 & 1 & 0 & 0 & 0 & 6 & 3 & 6 & 3 & 5 & 4 \\
\hline Q.7 & 3 & 2 & 1 & 2 & 4 & 5 & 0 & 4 & 2 & 5 \\
\hline Q.8 & 5 & 1 & 1 & 4 & 9 & 2 & 3 & 3 & 0 & 0 \\
\hline Q.9 & 1 & 0 & 0 & 0 & 1 & 0 & 4 & 3 & 3 & 16 \\
\hline Q.10 & 21 & 1 & 2 & 1 & 1 & 1 & 1 & 0 & 0 & 0 \\
\hline Q.11 & 1 & 1 & 1 & 1 & 2 & 3 & 3 & 4 & 1 & 11 \\
\hline Q.12 & 16 & 2 & 4 & 2 & 3 & 0 & 1 & 0 & 0 & 0 \\
\hline Q.13 & 2 & 0 & 2 & 1 & 7 & 0 & 3 & 5 & 1 & 7 \\
\hline Q.14 & 1 & 0 & 0 & 0 & 1 & 2 & 3 & 5 & 2 & 14 \\
\hline Q.15 & 17 & 2 & 0 & 2 & 2 & 2 & 1 & 1 & 1 & 0 \\
\hline Q.16 & 21 & 1 & 1 & 0 & 2 & 1 & 1 & 0 & 1 & 0 \\
\hline Q.17 & 18 & 0 & 2 & 1 & 3 & 0 & 1 & 1 & 0 & 2 \\
\hline Q.18 & 1 & 0 & 0 & 0 & 0 & 2 & 3 & 5 & 3 & 14 \\
\hline Q.19 & 0 & 0 & 0 & 0 & 4 & 2 & 1 & 6 & 4 & 11 \\
\hline Q.20 & 1 & 0 & 0 & 1 & 3 & 2 & 2 & 7 & 3 & 9 \\
\hline Q.21 & 4 & 2 & 3 & 2 & 7 & 4 & 2 & 1 & 3 & 0 \\
\hline Q.22 & 1 & 0 & 0 & 0 & 2 & 1 & 8 & 5 & 3 & 8 \\
\hline Q.23 & 0 & 0 & 0 & 0 & 3 & 1 & 4 & 9 & 5 & 6 \\
\hline Q.24 & 3 & 0 & 2 & 0 & 4 & 7 & 3 & 3 & 3 & 3 \\
\hline Q.25 & 3 & 0 & 0 & 1 & 7 & 0 & 4 & 4 & 4 & 5 \\
\hline Q.26 & 0 & 0 & 1 & 0 & 9 & 4 & 4 & 4 & 1 & 5 \\
\hline
\end{tabular}

Tabela 7. Na primeira linha estão as notas para cada questão, na primeira coluna o número da questão e o encontro de linhas e colunas representa o número de professores que atribuíram a respectiva nota. 
Continuação da tabela 7

\begin{tabular}{|l|c|c|c|c|c|c|c|c|c|c|}
\hline Q.27 & 0 & 0 & 0 & 1 & 3 & 2 & 5 & 5 & 3 & 9 \\
\hline Q.28 & 5 & 2 & 3 & 2 & 9 & 2 & 2 & 2 & 0 & 1 \\
\hline Q.29 & 1 & 0 & 0 & 0 & 0 & 1 & 2 & 3 & 2 & 19 \\
\hline Q.30 & 1 & 0 & 1 & 1 & 7 & 2 & 5 & 6 & 3 & 2 \\
\hline Q.31 & 8 & 5 & 2 & 1 & 6 & 2 & 4 & 0 & 0 & 0 \\
\hline Q.32 & 0 & 1 & 0 & 0 & 2 & 1 & 3 & 6 & 4 & 11 \\
\hline Q.33 & 5 & 0 & 2 & 1 & 4 & 3 & 5 & 1 & 3 & 3 \\
\hline Q.34 & 0 & 0 & 0 & 0 & 3 & 0 & 3 & 6 & 6 & 10 \\
\hline Q.35 & 0 & 0 & 0 & 0 & 0 & 0 & 4 & 2 & 7 & 15 \\
\hline Q.36 & 0 & 1 & 0 & 0 & 3 & 1 & 6 & 5 & 3 & 9 \\
\hline Q.37 & 3 & 0 & 0 & 2 & 7 & 0 & 3 & 5 & 4 & 4 \\
\hline Q.38 & 4 & 0 & 2 & 1 & 4 & 3 & 4 & 6 & 2 & 2 \\
\hline
\end{tabular}

Tabela 7. Na primeira linha estão as notas para cada questão, na primeira coluna o número da questão e o encontro de linhas e colunas representa o número de professores que atribuíram a respectiva nota. 


\title{
APÊNDICE 5 - Tabela 8. Opiniário aplicado aos professores de Ciências
}

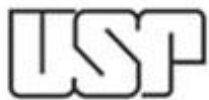 \\ UNIVERSIDADE DE SÃO PAULO \\ PROGRAMA INTERUNIDADES EM ENSINO DE CIÊNCIAS
}

Meu nome é Jacqueline C. Nogueira Contreiras e sou aluna do Programa Interunidades em Ensino de Ciências e como parte da minha pesquisa desejaria conhecer a sua opinião sobre alguns assuntos que estão vinculados à sala de aula e ao trabalho do professor. Gostaria de contar com a sua valiosa colaboração respondendo as perguntas abaixo:

Nome (não há necessidade de colocar sobrenome):

Sexo: $\quad$ Masculino $\square \quad$ Feminino $\square$

Faixa etária

18-24 anos

25-34 anos

$35-44$ anos

45-54 anos

+ de 55 anos

\section{Nível educacional:}

Superior completo

Mestrado incompleto

Mestrado

Doutorado incompleto

Doutorado

Área de formação inicial e disciplina que leciona atualmente:

Tempo de magistério:

A seguir são mostradas 15 afirmações elaboradas a partir das idéias de um grande biólogo e pensador moderno que tem trabalhado na área de educação. Por favor, antes de responder, leia detidamente cada frase até compreendê-la. Posteriormente,utilizando a escala abaixo, de uma nota para indicar o quanto você concorda ou discorda com cada uma das afirmações mostradas na tabela abaixo.

$$
\begin{aligned}
& 9 \text { - Concordo totalmente } \\
& 8 \text { - Concordo muito } \\
& 7 \text { - Concordo moderadamente } \\
& 6 \text { - Concordo ligeiramente } \\
& 5 \text { - Nem Concordo / nem discordo }
\end{aligned}
$$


4 - Discordo ligeiramente

3 - Discordo moderadamente

2 - Discordo muito

1 - Discordo totalmente

\begin{tabular}{|c|c|c|}
\hline № & AFIRMAÇÃO & NOTA \\
\hline 1 & $\begin{array}{l}\text { As diferentes emoções, tanto positivas quanto negativas, regulam a } \\
\text { linguagem dentro de sala de aula o que favorece a manifestação de } \\
\text { condutas diferentes. }\end{array}$ & \\
\hline 2 & As emoções definem nossa racionalidade, ou seja, como pensamos. & \\
\hline 3 & $\begin{array}{l}\text { Professores e alunos interagem permanentemente uns com os } \\
\text { outros de modo espontâneo e recíproco. }\end{array}$ & \\
\hline 4 & $\begin{array}{l}\text { O amor é a condição espontânea para a aceitação do outro como } \\
\text { legítimo outro, para a convivência em uma sala de aula. }\end{array}$ & \\
\hline 5 & $\begin{array}{l}\text { O amor é o fundamento do social, porque ao permitir a coexistência } \\
\text { do outro conosco, permite a nossa socialização através da } \\
\text { linguagem. Portanto, é o amor que permitiu nossa história evolutiva. }\end{array}$ & \\
\hline 6 & $\begin{array}{l}\text { É possível conscientemente através da linguagem e da razão } \\
\text { identificar e mudar as nossas emoções em qualquer contexto, } \\
\text { escolar ou não. }\end{array}$ & \\
\hline 7 & $\begin{array}{l}\text { Em sala de aula, as interações entre os indivíduos provocam } \\
\text { mudanças de comportamentos uns nos outros e isso gera } \\
\text { transformações. }\end{array}$ & \\
\hline 8 & $\begin{array}{l}\text { A linguagem nos auxilia na contemplação e na reflexão sobre o } \\
\text { mundo em que vivemos. }\end{array}$ & \\
\hline 9 & $\begin{array}{l}\text { Através da linguagem nos tornamos seres mais conscientes de nós } \\
\text { mesmos e conscientes do mundo. }\end{array}$ & \\
\hline 10 & $\begin{array}{l}\text { Quando afirmamos que somos seres racionais, menosprezamos as } \\
\text { emoções e exaltamos a racionalidade. }\end{array}$ & \\
\hline 11 & $\begin{array}{l}\text { Qualquer explicação ou descrição que fazemos da realidade está } \\
\text { associada à nossa própria experiência. }\end{array}$ & \\
\hline 12 & $\begin{array}{l}\text { Todas as explicações que um indivíduo dá sobre a realidade são } \\
\text { válidas e legítimas, mesmo que os outros as considerem erradas. }\end{array}$ & \\
\hline 13 & $\begin{array}{l}\text { Através da conversação e da linguagem na sala de aula o professor } \\
\text { pode abrir caminhos para a reflexão. Desta forma seu aluno não } \\
\text { será negado em suas dificuldades e sim respeitado como um ser } \\
\text { individual, único e legítimo. }\end{array}$ & \\
\hline
\end{tabular}




\begin{tabular}{|c|l|l|}
\hline 14 & $\begin{array}{l}\text { Para que a sala de aula seja um espaço de promoção da inteligência } \\
\text { e da criatividade dos alunos, não se pode avaliar a pessoa do aluno, } \\
\text { apenas avaliar o que esse aluno faz. }\end{array}$ & $\begin{array}{l}\text { As nossas emoções mudam nossas ações e em conseqüência, } \\
\text { mudam também a forma de nos comunicarmos e a nossa maneira } \\
\text { de pensar. }\end{array}$ \\
\hline 15
\end{tabular}

Em seguida, por favor, responda sinceramente e de forma breve, clara e simples às seguintes perguntas:

1. Conhece as idéias do pensador Humberto Maturana? Sim $\square$ Não $\square$

2. Se sua resposta a pergunta anterior fosse afirmativa, que obras do autor conhece?

3. Crê que este autor pode dar uma contribuição para o ensino nas escolas? Em caso afirmativo, explique brevemente suas razões.

4. Ao responder este opiniário algumas reflexões podem ter surgido. Este espaço é destinado para as suas reflexões, críticas e comentários que você ache pertinentes. Sinta-se a vontade para escrever seus comentários, os quais serão de grande valia para este trabalho de pesquisa. 
APÊNDICE 6- Tabela 9 Respostas dos professores às afirmações do opiniário.

\begin{tabular}{|c|c|c|c|c|c|c|c|c|c|c|c|c|c|c|c|}
\hline \multirow{2}{*}{ 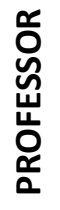 } & \multicolumn{15}{|c|}{ Nota da afirmação } \\
\hline & 1 & 2 & 3 & 4 & 5 & 6 & 7 & 8 & 9 & 10 & 11 & 12 & 13 & 14 & 15 \\
\hline 1 & 9 & 6 & 7 & 3 & 1 & 9 & 8 & 7 & 7 & 2 & 9 & 8 & 7 & 8 & 8 \\
\hline 2 & 8 & 8 & 6 & 9 & 9 & 6 & 8 & 9 & 7 & 7 & 7 & 9 & 9 & 7 & 8 \\
\hline 3 & 8 & 5 & 8 & 5 & 4 & 5 & 7 & 9 & 8 & 9 & 9 & 5 & 9 & 8 & 5 \\
\hline 4 & 9 & 8 & 7 & 7 & 6 & 8 & 8 & 9 & 9 & 2 & 4 & 2 & 9 & 9 & 9 \\
\hline 5 & 8 & 8 & 7 & 6 & 6 & 8 & 8 & 8 & 9 & 6 & 9 & 9 & 6 & 8 & 8 \\
\hline 6 & 8 & 4 & 6 & 4 & 4 & 7 & 7 & 9 & 9 & 3 & 5 & 7 & 8 & 8 & 8 \\
\hline 7 & 9 & 9 & 1 & 1 & 7 & 4 & 7 & 9 & 9 & 9 & 9 & 1 & 9 & 1 & 9 \\
\hline 8 & 8 & 5 & 7 & 9 & 9 & 7 & 9 & 9 & 9 & 3 & 7 & 3 & 9 & 3 & 9 \\
\hline 9 & 7 & 6 & 7 & 8 & 7 & 8 & 8 & 9 & 8 & 6 & 7 & 6 & 8 & 1 & 7 \\
\hline 10 & 8 & 4 & 2 & 5 & 5 & 7 & 7 & 7 & 8 & 2 & 9 & 1 & 8 & 4 & 7 \\
\hline 11 & 7 & 6 & 7 & 6 & 7 & 6 & 7 & 8 & 9 & 4 & 7 & 5 & 9 & 9 & 6 \\
\hline 12 & 8 & 8 & 7 & 6 & 6 & 6 & 7 & 8 & 7 & 4 & 7 & 3 & 8 & 4 & 8 \\
\hline 13 & 7 & 8 & 8 & 7 & 8 & 8 & 8 & 8 & 8 & 7 & 6 & 7 & 8 & 7 & 6 \\
\hline 14 & 9 & 8 & 8 & 9 & 8 & 9 & 9 & 8 & 9 & 8 & 9 & 9 & 8 & 8 & 8 \\
\hline 15 & 9 & 9 & 1 & 8 & 8 & 3 & 9 & 9 & 9 & 6 & 9 & 8 & 8 & 1 & 9 \\
\hline 16 & 9 & 7 & 9 & 9 & 7 & 8 & 8 & 9 & 8 & 9 & 9 & 9 & 9 & 8 & 8 \\
\hline 17 & 9 & 6 & 2 & 6 & 6 & 2 & 9 & 9 & 9 & 6 & 9 & 7 & 9 & 1 & 9 \\
\hline 18 & 6 & 1 & 7 & 7 & 7 & 7 & 8 & 8 & 8 & 1 & 2 & 2 & 9 & 3 & 3 \\
\hline 19 & 7 & 4 & 8 & 2 & 3 & 8 & 9 & 9 & 8 & 1 & 1 & 4 & 9 & 1 & 8 \\
\hline 20 & 8 & 7 & 9 & 6 & 7 & 7 & 8 & 9 & 9 & 4 & 8 & 8 & 9 & 1 & 8 \\
\hline 21 & 8 & 9 & 9 & 9 & 9 & 5 & 9 & 9 & 9 & 1 & 4 & 9 & 9 & 4 & 8 \\
\hline 22 & 9 & 9 & 6 & 8 & 8 & 9 & 9 & 8 & 7 & 4 & 8 & 5 & 8 & 6 & 8 \\
\hline 23 & 8 & 7 & 6 & 8 & 8 & 6 & 7 & 8 & 8 & 2 & 7 & 8 & 8 & 4 & 7 \\
\hline 24 & 5 & 6 & 5 & 5 & 5 & 5 & 9 & 7 & 9 & 5 & 9 & 7 & 9 & 7 & 7 \\
\hline 25 & 8 & 8 & 8 & 6 & 7 & 7 & 8 & 9 & 9 & 8 & 8 & 6 & 9 & 8 & 7 \\
\hline 26 & 9 & 8 & 7 & 9 & 7 & 6 & 9 & 9 & 9 & 9 & 9 & 6 & 9 & 9 & 9 \\
\hline 27 & 8 & 6 & 9 & 7 & 6 & 8 & 9 & 8 & 8 & 8 & 9 & 9 & 9 & 9 & 9 \\
\hline 28 & 9 & 1 & 6 & 7 & 7 & 9 & 9 & 9 & 9 & 1 & 6 & 1 & 9 & 9 & 1 \\
\hline 29 & 5 & 4 & 6 & 6 & 6 & 9 & 9 & 9 & 8 & 4 & 8 & 6 & 9 & 1 & 6 \\
\hline 30 & 8 & 8 & 7 & 7 & 8 & 4 & 9 & 9 & 9 & 8 & 9 & 8 & 9 & 8 & 9 \\
\hline 31 & 7 & 6 & 4 & 8 & 4 & 8 & 8 & 8 & 8 & 6 & 8 & 4 & 8 & 3 & 8 \\
\hline 32 & 5 & 5 & 6 & 5 & 6 & 5 & 8 & 8 & 8 & 5 & 8 & 7 & 8 & 4 & 8 \\
\hline 33 & 8 & 7 & 7 & 3 & 5 & 6 & 8 & 8 & 8 & 7 & 6 & 2 & 8 & 4 & 8 \\
\hline 34 & 7 & 8 & 9 & 9 & 9 & 5 & 8 & 9 & 9 & 9 & 9 & 9 & 7 & 9 & 6 \\
\hline 35 & 5 & 5 & 6 & 6 & 6 & 7 & 7 & 8 & 7 & 5 & 6 & 5 & 7 & 6 & 6 \\
\hline 36 & 8 & 7 & 6 & 1 & 1 & 6 & 8 & 9 & 9 & 1 & 9 & 1 & 9 & 1 & 2 \\
\hline
\end{tabular}




\begin{tabular}{|l|l|l|l|l|l|l|l|l|l|l|l|l|l|l|l|}
37 & 9 & 8 & 7 & 6 & 6 & 8 & 9 & 9 & 9 & 2 & 8 & 8 & 8 & 7 & 8 \\
\hline 38 & 7 & 8 & 5 & 7 & 7 & 6 & 7 & 8 & 7 & 6 & 8 & 5 & 7 & 4 & 7 \\
\hline 39 & 6 & 8 & 1 & 8 & 6 & 6 & 5 & 8 & 8 & 5 & 5 & 7 & 8 & 1 & 6 \\
\hline $\mathbf{4 0}$ & 8 & 7 & 8 & 7 & 6 & 8 & 8 & 8 & 8 & 5 & 8 & 4 & 8 & 6 & 9 \\
\hline $\mathbf{4 1}$ & 8 & 8 & 4 & 7 & 6 & 6 & 9 & 9 & 9 & 6 & 7 & 4 & 9 & 1 & 7 \\
\hline $\mathbf{4 2}$ & 8 & 7 & 3 & 5 & 2 & 6 & 8 & 9 & 9 & 4 & 6 & 3 & 8 & 8 & 9 \\
\hline $\mathbf{4 3}$ & 9 & 8 & 4 & 4 & 4 & 9 & 9 & 9 & 9 & 4 & 9 & 9 & 6 & 4 & 8 \\
\hline $\mathbf{4 4}$ & 7 & 2 & 2 & 6 & 5 & 6 & 8 & 8 & 7 & 4 & 6 & 5 & 7 & 2 & 6 \\
\hline $\mathbf{4 5}$ & 6 & 6 & 5 & 7 & 6 & 5 & 6 & 7 & 9 & 7 & 7 & 6 & 7 & 6 & 6 \\
\hline $\mathbf{4 6}$ & 8 & 8 & 4 & 4 & 6 & 8 & 8 & 8 & 8 & 6 & 6 & 7 & 8 & 4 & 7 \\
\end{tabular}

Tabela 8: A primeira coluna indica o professor, a primeira e a segunda linha indicam as afirmações. A intersecção de linha e coluna indica a nota dada pelo professor para a respectiva afirmação. 


\section{APÊNDICE 7- Tabela de identificação dos professores}

\begin{tabular}{|c|c|c|c|c|}
\hline PROF. & SEXO & FAIXA ETÁRIA & DISCIPLINA & TEMPO DE SERVIÇO \\
\hline 1 & $\mathrm{~F}$ & $45-54$ & QUÍMICA & 20 anos \\
\hline 2 & $\mathrm{~F}$ & $25-34$ & QUÍMICA & 2 anos \\
\hline 3 & $\mathrm{~F}$ & mais de 55 & QUIIMICA & 22 anos \\
\hline 4 & M & $35-44$ & QUÍMICA & 6 anos \\
\hline 5 & $M$ & $45-54$ & QUIIMICA & 25 anos \\
\hline 6 & $M$ & $35-44$ & QUÍMICA & 6 anos \\
\hline 7 & $\mathrm{~F}$ & $35-44$ & FÍSICA & 14 anos \\
\hline 8 & $\mathrm{~F}$ & $25-34$ & FÍSICA & 7 anos \\
\hline 9 & $\mathrm{~F}$ & mais de 55 & FÍSICA & 20 anos \\
\hline 10 & $\mathrm{~F}$ & $18-24$ & FÍSICA & 2 anos \\
\hline 11 & $M$ & mais de 55 & FÍSICA & 22 anos \\
\hline 12 & $M$ & $35-44$ & FÍSICA & 4 anos \\
\hline 13 & $M$ & mais de 55 & FÍSICA & 33 anos \\
\hline 14 & M & $35-44$ & FÍSICA & 11 anos \\
\hline 15 & $M$ & $18-24$ & FÍSICA & 1 ano \\
\hline 16 & $\mathrm{~F}$ & $35-44$ & BIOLOGIA & 3 anos \\
\hline 17 & $\mathrm{~F}$ & mais de 55 & BIOLOGIA & 25 anos \\
\hline 18 & $\mathrm{~F}$ & $45-54$ & BIOLOGIA & 25 anos \\
\hline 19 & $\mathrm{~F}$ & $25-34$ & BIOLOGIA & 3 anos \\
\hline 20 & $\mathrm{~F}$ & $45-54$ & BIOLOGIA & 21 anos \\
\hline 21 & $\mathrm{~F}$ & $25-34$ & BIOLOGIA & 9 anos \\
\hline 22 & $\mathrm{~F}$ & $35-44$ & BIOLOGIA & 4 anos \\
\hline 23 & $\mathrm{~F}$ & $45-54$ & BIOLOGIA & 25 anos \\
\hline 24 & $\mathrm{~F}$ & $25-34$ & BIOLOGIA & 5 anos \\
\hline 25 & $\mathrm{~F}$ & $25-34$ & BIOLOGIA & 4 anos \\
\hline 26 & $\mathrm{~F}$ & $35-44$ & BIOLOGIA & 10 anos \\
\hline 27 & $\mathrm{~F}$ & $35-44$ & BIOLOGIA & 5 anos \\
\hline 28 & $\mathrm{~F}$ & $45-54$ & BIOLOGIA & 25 anos \\
\hline 29 & $\mathrm{~F}$ & $25-34$ & BIOLOGIA & 1 ano \\
\hline 30 & $\mathrm{~F}$ & $35-44$ & BIOLOGIA & 18 anos \\
\hline 31 & $\mathrm{~F}$ & $25-34$ & BIOLOGIA & 8 anos \\
\hline 32 & $\mathrm{~F}$ & $18-24$ & BIOLOGIA & 2 anos \\
\hline 33 & $M$ & $45-54$ & BIOLOGIA & 17 anos \\
\hline 34 & $M$ & $25-34$ & BIOLOGIA & 11 anos \\
\hline 35 & $M$ & $25-34$ & BIOLOGIA & 11 anos \\
\hline 36 & $\mathrm{M}$ & $45-54$ & BIOLOGIA & 28 anos \\
\hline 37 & $\mathrm{M}$ & $25-34$ & BIOLOGIA & 7 anos \\
\hline
\end{tabular}

Tabela 9. Identificando o sexo, idade, tempo de serviço e disciplina de cada professor de nossa amostra. 
Continuação da tabela 9

\begin{tabular}{|c|c|c|c|c|}
\hline PROF. & SEXO & FAIXA ETÁRIA & DISCIPLINA & TEMPO DE SERVIÇO \\
\hline 38 & $\mathrm{M}$ & $25-34$ & BIOLOGIA & 2 anos \\
\hline 39 & $\mathrm{M}$ & $18-24$ & BIOLOGIA & 1 ano \\
\hline 40 & $\mathrm{~F}$ & $18-24$ & MATEMÁTICA & 1 ano \\
\hline 41 & $\mathrm{~F}$ & mais de 55 & MATEMÁTICA & 30 anos \\
\hline 42 & $\mathrm{~F}$ & $35-44$ & MATEMÁTICA & 19 anos \\
\hline 43 & $\mathrm{~F}$ & $25-34$ & MATEMÁTICA & 13 anos \\
\hline 44 & $\mathrm{M}$ & $35-44$ & MATEMÁTICA & 10 anos \\
\hline 45 & $\mathrm{M}$ & $45-54$ & MATEMÁTICA & 20 anos \\
\hline 46 & $\mathrm{M}$ & $35-44$ & MATEMÁTICA & 10 anos \\
\hline
\end{tabular}

Tabela 9. Identificando o sexo, idade, tempo de serviço e disciplina de cada professor de nossa amostra. 


\section{APÊNDICE 8 - Transcrição das respostas da questão no 3}

\section{Questão 3: Crê que este autor pode dar uma contribuição para o ensino nas escolas? Em caso afirmativo, explique brevemente suas razões.}

Prof. 02 Pelo pouco que conheço desse autor, penso que suas ideias podem contribuir para o ensino, no que se refere às relações entre professores e alunos. $A$ partir do momento em que há uma relação respeitosa e harmoniosa em sala de aula, onde professor e alunos se respeitam e respeitam as diversas opiniões e culturas existentes em sala de aula, o aprendizado pode ser mais proveitoso visto que, o aluno, sentindo-se seguro para expor suas opiniões, dúvidas e pensamentos, pode aproveitar melhor o conhecimento compartilhado em sala.

Prof. 03 Claro que sim, fundamentalmente na formação dos professores que finalmente são aqueles que estabelecem relações com os alunos e mediam relações entre eles.

A ideia do professor criador do espaço da convivência onde exista possibilidade de convidar ou não a momentos de reflexão, determina o sucesso de um ambiente de ensino aprendizagem. Essa dinâmica participativa vem diretamente dele, se ele sentir que isto é importante, deixará espaços o portas abertas para que os alunos possam vivenciar momentos de empoderamento e aí que aparece um possível protagonismo juvenil.

Outro aspecto que acho interessante dele para ser utilizado no processo de ensino aprendizagem é esse conhecer associado com o observador, ou seja, que o conhecimento não é simplesmente receber um conjunto de informações e sim como esse observador interpreta o compreende essa informação. Isto permite que os docentes possam ver a seus alunos como indivíduos e não esperar deles resultados iguais

Prof.06 Acredito, mesmo não conhecendo o trabalho do autor. Toda produção humana realizada no intuito de conhecer os caminhos da cognição é de grande valia para a Sociedade. 
Prof. 08 Sim. Professores precisam se posicionar epistemológica e metodologicamente. Sendo assim, a epistemologia de Maturana pode ser conhecida e adotada como referencial privilegiado por alguns professores. O que não pode ocorrer é o que temos em sala de aula hoje em dia, falta de clareza e confusão epistemológica e metodológica.

Obs. Acho que não era bem essa a resposta que gostaria de ler. Mas, fiquei pensando sobre algumas colocações da epistemologia de Maturana que considero importantes, como por exemplo: (i) as que envolvem as questões por que, para que o que ensinar; (ii) as concepções de realidade e explicação; e, (iii) principalmente a concepção biologia do ser humano como autopoiético). O problema é que algumas dessas, mesmo sendo de uma epistemologia biológica, chocam com concepções que adoto/acredito/compartilho da epistemologia da ciência e em alguns momentos elas se complementam e em outros se distanciam. Ainda não sei como elas se interacionam em sala de aula ou mesmo, se são compatíveis, não tenho opiniões claras. Por isso, justifico meu SIM a pergunta pela necessidade de que os professores se posicionem epistemológica e metodologicamente.

Prof. 12 As emoções fazem parte do nosso dia a dia, a razão e a emoção andam juntas não somos seres dicotômicos ou polarizados, e isso acontece no ambiente escolar, influenciando nas nossas ações e decisões, se o autor ajuda a compreendêlas ele pode fornecer uma importante contribuição a discussão.

Prof. 16Eu ainda não li os livros do Maturana, mas sei que ele propõe uma nova visão de homem, considerando a emoção. Eu acredito muito que esta visão possa contribuir para o ensino nas escolas, inclusive neste momento de mudança, acho necessária esta abordagem para de fato ter uma educação que faça a diferença.

Prof. $19 \mathrm{Sim}$, pois o autor valoriza o aluno como indivíduo que reage a diferentes emoções e não apenas por seus atos.

Prof. 20 Sim. São interessantes as suas ideias de que a educação não deve se pautar na competição, que só exclui e impede que enxerguemos o outro como legítimo outro. Também é interessante a defesa que faz de que as relações que se estabelecem no ambiente escolar devem buscar a cooperação, valorizando a convivência entre as pessoas e que o objetivo da educação não deve ser pautada 
na busca mercadológica, mas na convivência entre as pessoas. A relação entre as pessoas, a conversa e a amorosidade passam a ter um papel importante na ação educativa. Entretanto penso que o sistema escolar atual não oferece condições para a adoção dessas ideias.

Prof. 23 Como não conheço as obras do autor, não consigo opinar se contribui ou não para o ensino. Porém, acredito que coisas boas podem ser extraídas de suas obras.

Prof. $25 \mathrm{Sim}$, pois parece que ele trabalha com diferentes conexões "neuronais" que envolve o conhecimento.

Prof. 26 Sim. A escola é uma instituição alicerçada nas relações humanas e um olhar mais profundo sobre essas relações pode oferecer alternativas à crise que a escola vem sofrendo nos últimos anos. Maturana ao descrever a importância da aceitação legítima do outro põe em evidência a relação professor-aluno e como esta pode ser reconhecida como legitima.

Prof. 27 Creio que sim, pelas afirmações que li aqui, acredito que a maior contribuição seja ajudar-nos a repensar as relações humanas, como se estabelecem, quais seriam as condições de atitude racional e afetiva para que um diálogo de verdade possa ser estabelecido entre professor e aluno (entre pessoas). Parece que com essas condições pode haver entendimento e crescimento de todos que estão "em relação". O respeito ao pensamento do outro é outra coisa importante na fala do autor.

Prof. 28 Minhas leituras sobre as obras citadas foram apenas de cunho informal. Gosto de variar títulos e obras. No caso do referido autor, encantou-me as questões abordadas sobre as relações humanas.

Como Educadora, acredito que a aprendizagem é feita por meio da relação, de uma boa relação. Estou certa de que meus alunos aprendem aquilo que tem significado em suas vidas e, a capacidade de dar significado ao conhecimento é de cunho do Professor. 
Prof. 29 Os estudos de Maturana contribuir no ambiente escolar porque ocorre fenômenos sociais, como as emoções, os pensamentos, os conceitos e através dessas interações, os alunos mudam seu comportamento e sua socialização.

Prof.30 Sim. Principalmente nas ideias de aprender como sinônimo de "autoorganização" e nas relações entre" aprende-se vivendo - vive-se aprendendo", quando um ser vivo deixa de" aprender" ele deixa de viver. Nestes conceitos podese compreender o estudante e professor como "um corpo aprendente", em que as múltiplas dimensões que nos constituem estão inter-relacionadas no processo de aprender. Assim aprende-se de corpo inteiro! Cada novo aprender auto-organiza todo o nosso corpo (físico, cognitivo, emocional, afetivo...).

Prof. 37 Partindo do princípio que cada indivíduo tem a sua percepção do mundo a forma de ensino enlatada, que não dá espaço para o aluno explicitar suas experiências e compreensões.

Prof. $39 \mathrm{Sim}$. Penso isso, pois no meio acadêmico raramente se fala que um professor, na sua prática em sala de aula, deve ter afeto e amor aos seus alunos. Para mim, aí está um dos pontos chave que alguém deve levar em consideração no momento em que decide se torna professor. Este deve sempre refletir e lembrar que assim como ele próprio, seus alunos possuem emoções que devem ser levadas em conta. Em minha opinião, a falta de amor ao próximo é uma das causas deste sistema educacional falido. Outro fato importante considerado pelo Maturana é a Linguagem e a Conversação, outro defeito encontrado na sala de aula, pois alunos e professores, em muitos casos, dificilmente conseguem ter uma conversa a ponto de estabelecer um elo de amizade. 


\section{APÊNDICE 9 - Transcrição das respostas da questão nำ}

Questão 4 Ao responder este opiniário algumas reflexões podem ter surgido. Este espaço é destinado para as suas reflexões, críticas e comentários que você ache pertinentes. Sinta-se a vontade para escrever seus comentários, os quais serão de grande valia para este trabalho de pesquisa.

Prof. 01 Eu achei interessante a discussão sobre a relação entre emoção e razão e como isso influencia as relações em sala de aula. Chamando a atenção para que os indivíduos tem que aprender a lidar com suas próprias emoções e as do grupo dentro de uma sala de aula. O grande problema estar em harmonizar os conflitos e direcionar os resultados como auxiliar da aprendizagem.

Prof. $05 \mathrm{Na}$ verdade nem sempre resulta fácil concordar ou discordar porque preenchendo este questionário eu olhava as frases desde lugares diferentes e então tentava responder desde cada lugar e as respostas foram diferentes. Porem tive que decidir por um numero em cada caso. Algumas afirmações têm mais de uma afirmação dentro delas $(5,6,7,12)$ e então novamente, decidi por alguma.

Imagino que se tivesse que responder este questionário em um momento de raiva seria mais Maturanista ainda... Tomara minhas respostas sejam úteis para você! Boa dissertação!

Prof. 06 No opiniário, você utilizou o termo amor. Acredito que dentro os entrevistados possam haver concepções divergentes quanto ao termo que possam influenciar as respostas.

Prof. 09 Este opiniário despertou meu interesse no que diz respeito às ideias do pensador chileno Humberto Maturana que, realmente, eu desconhecia.

Prof. 11 Não conheço o pensamento do pensador Humberto Maturana, se o questionário proposto é compatível com sua forma de pensar em educação ele ou se ele propões uma relação entre os alunos e professores baseados do tratamento amoroso entre as partes e que este relacionamento quando entra em conflito poderá 
originar mudanças no quadro emotivo dará origem a uma mudança de comportamento e de compreensão do tema abordado.

Prof. 12 Tanto na academia quanto na escola tenta-se separar o emocional do racional por vários motivos e muitos inclusive de caráter histórico devido ao ensino religioso. Porém ignorar que somos seres que tem sentimentos e que eles estão presentes no processo educativo é um equívoco.

Prof.15 As emoções são fatores inexoráveis de nossa existência e toda nossa linguagem nada mais é do que uma forma de expressá-las, tudo o que fazemos , seja em uma sala de aula, seja no cotidiano, é dividir nossas experiências, desejos e futuros, compartilhar justamente o que nos torna humanos, no sentido mais verdadeiro da palavra, que é o conhecimento.

Prof. 16 E adorei ter participado deste opiniário, inclusive fiquei muito feliz em saber que este tipo de estudo está sendo feito, parabéns e obrigada pela oportunidade.

Prof. $17 \mathrm{Eu}$ considero que outras emoções além do amor estão envolvidas no relacionamento humano. Além disso, as relações de amor em casa também influem na maneira como o aluno (e o professor) lidam com esta emoção nas atividades escolares. A história de vida das pessoas deve influir muito mais do que sentimentos isolados, porque somos um todo.

Prof. 18 Apesar de não conhecer o autor, as questões são sempre oportunas. porque leva a uma nova reflexão de nossas práticas educativas. E fiquei interessada em saber mais sobre o autor

Prof. 19 A linguagem utilizada nas afirmações é um pouco complexas demais.

Prof. 20 Considero as ideias de Maturana muito difíceis de serem colocadas em prática em uma sociedade que é competitiva por excelência. O próprio acesso à Universidade consiste em um processo exclusivo e não inclusivo. Nas escolas particulares, via de regra, não há espaço para proporcionar maior diálogo entre professor/alunos e nem para se estabelecer uma relação de convivência mais amorosa porque há uma corrida contínua contra o tempo para se conseguir cumprir o "planejamento". 
Eu me pergunto como é possível conhecer o outro e reconhecer no outro se geralmente nem o nome da maioria dos alunos o professor consegue aprender porque eles são muitos e o tempo de convivência limita-se a menos de 3 horas por semana.

Prof. $23 \mathrm{Na}$ verdade a crítica é para a minha própria pessoa. Talvez eu tenha que ler mais obras voltadas à educação. Com certeza teria respondido descentemente as três ultimas perguntas.

Prof. 24 Acho que o professor deve abrir espaço para ouvir o aluno. Vivemos em uma sociedade aprendente.

Prof. $27 \mathrm{Na}$ afirmação 4, não concordo que o amor seja condição espontânea para a aceitação do outro. Acho que é condição essencial, porém trabalho da Vontade. Na questão 2, não concordo que as emoções definam a racionalidade, mas que ambas se construam mutuamente. Na questão 5 , não sei se é exclusivamente o amor que nos mantém unidos ou com um sentimento de identificação como "humanidade", talvez seja isso, mas acho que existem outros fatores como a necessidade do outro, o interesse, o "uso do outro" como fator de agregação temporária, ou desagregação social. Nossa história evolutiva quer dizer nossa "não extinção como espécie"? Acho que o afeto está nos mamíferos, com certeza, e faz criar laços. Não sei se a inteligência, memória e engenhosidade não tiveram um papel fundamental... Acho que o amor está em extinção (se se aprende a amar sendo amado, e amando por decisão, mais que por esperança). Acho que só por um Amor Maior (Deus) é possível ainda alguma Esperança para o ser humano e para a Terra. Acho que o nosso amor é uma resposta quase milagrosa a esse amor maior. Acho que pela confiança que o amor gera é possível que alguém aceite deixar-se tocar, deixar-se transformar e recomeçar, e assim crescer como pessoa, não apenas cognitivamente. Questão 8, acho que a linguagem nos ajuda a "entender" ou "explicar" o que sentimos de forma não racional, como na contemplação, que acho que está além da razão, que existe em nós antes da palavra. Questão 9, conscientes da explicação que damos para nós mesmos e para o mundo... o que é meio limitado de certa maneira (parece um paradoxo), acho que pela relação que estabelecemos com as pessoas e o mundo nos conhecemos. Achei muito bacana pensar sobre tudo isso e me ajudou a me compreender melhor minha maneira de ser, e achar que "nem tudo 
está perdido", que o esforço de dialogar e amar pode valer a pena. Muito obrigada pela oportunidade!

Prof. 28 Reitero que a gestão da sala de aula é de responsabilidade do Professor. Demonstrar respeito pelas diferenças e ter em mente a formação integral do ser humano (valores para a cidadania e relações interpessoais e acadêmica) é uma das ações que deve fazer parte do currículo pessoal de um Docente. Sou uma profissional de sucesso, estou há 24 anos em uma mesma Escola, um Colégio particular da Cidade de São Paulo, de filosofia Dominicana e formação tradicional. Obtenho excelentes resultados junto aos meus alunos (e ex-alunos, muitos dos quais seguiram a Área por influência de minhas aulas). Sei que a sala de aula é o meu lugar e, apesar de ter me doutorado na área de Pesquisa Aplicada Biotecnologia, jamais abandonei a sala de aula e nunca o farei.

Aprendi que, mais importante do que notas e resultados numéricos, é a forma como meus alunos utilizam os conhecimentos apreendidos em sala de aula para suas vidas e para a melhoria das condições de vida da Sociedade em que vivem.

Sou MUITO feliz por estar à frente de uma sala de aula e sei que aqueles "olhinhos" apaixonados pela Biologia são parte daquilo que acredito: A Ciência como Verdade.

Prof. 30 Na questão 6 e 8: "linguagem e da razão" e "Através da conversação e da linguagem" não compreendo como coisas distintas ou separadas

Na questão 12: "Todas as explicações que um indivíduo dá sobre a realidade são válidas e legítimas, mesmo que os outros as considerem erradas" - é preciso considerar o contexto em que elas são elaboradas, se não "tudo vale", cai-se no relativismo. Entendo que, principalmente no espaço da sala de aula, o professor precisa incentivar e valorizar diferentes formas de ver o mundo, mas considerando sempre o "contexto", ou como se diz nos estudos de linguagem "em que formação discursiva" se está falando.

Prof. $33 \mathrm{Na}$ questão 12, quando afirma que "é valida e legítima", é válida e legítima para quê? Em que contexto devo considerar essa validade e legitimidade? No nível do indivíduo, certamente. No nível da sociedade, não. Casos contrário, por absurdo, 
teríamos que considerar legitimas ideias homicidas, racistas, pedofílicas e coisas do gênero.

Prof. 34 A sociedade, dominada pela cultura de massa e explicada pelas teorias sociais, perdeu a identidade do indivíduo, que somente com o amor, ressalta a sua existência como ser único em convivência com o outro. Desse modo as ideias de Maturana, devolve a capacidade do emocional em coparticipação com o racional, e isso influência no relacionamento entre os educandos e o processo de aprendizagem.

Prof. 35 Achei de extrema importância o estudo direcionado ao "comportamento" do ser humano como um todo, em especial dos educandos. Espero que tal levantamento venha a contribuir (de alguma forma) para a melhora da qualidade de nossa educação e, por que não dizer, de nossa convivência com nossos alunos no dia-a-dia!

Prof. 37 Somos racionais e suscetíveis as emoções, cada um num grau maior ou menor, assim como a reação num momento de tensão pode ser a fuga ou o enfrentamento, sendo assim achei algumas afirmações um tanto generalistas.

Prof. 41 Uma boa dose de percepção em relação a fraqueza ou carência do grupo e com palavras e atitudes adequadas pode-se criar um ambiente saudável de relacionamento (confiança) que venha promover a aprendizagem desejada.

Prof 42 Acredito que as emoções (boas ou ruins) quando muito exaltadas alteram nosso comportamento e relação com os demais. Mas não entendo que elas são as únicas determinantes do processo de interação entre as pessoas e de educação. Para mim existem NECESSIDADES básicas e secundárias ( que surgem no processo da vida) e que determinam realmente a interação entre as pessoas. Por exemplo, necessidade de alimentação, de abrigo, e neste caso de educação. A necessidade de educação não é natural ao estudante, mas pode ser compreendida se ele também perceber que faz parte de uma sociedade e que para viver nela precisa dos conhecimentos adquiridos pela humanidade ao longo dos séculos. Sobre a linguagem, ela é fundamental para a interação, para comunicação, para a expressão das emoções, para a conscientização de nossa própria maneira de pensar enfim. No processo de interação professores e estudantes mais importante 
do que o Amor (que considero um sentimento fortíssimo e poderoso) é o respeito que devemos ter com todos como habitantes do mesmo planeta, sem grau de superioridade ou inferioridade demarcado por questões sociais, raciais, econômicas etc., mas isso independe do amor.

Prof. 43 A reflexão que faço, é que a comunicação entre professores e alunos precisa ser constante e de boa qualidade. Professores e alunos precisam encontrar um ponto de equilíbrio para que o ensino e a aprendizagem aconteça, pois as emoções estão muito ligadas ao dar e receber de cada um.

$\mathrm{Na}$ minha visão, não acredito que haja aprendizagem significativa num ambiente hostil. Conquiste o grupo. Assim terá todos ao seu lado, caminhando na mesma direção, mesmo que em velocidades diferentes. Haverá mais prazer de ambos os lados. 


\section{APÊNDICE 10 - Termo de Consentimento}

\section{TERMO DE CONSENTIMENTO DE PARTICIPAÇÃO EM PESQUISA}

Consentimento $\mathrm{n}^{\mathrm{o}} 13$

Declaro ter sido esclarecido a respeito das informações e atividades que farão parte da pesquisa A sala de aula, o estar junto e a transformação sob a perspectiva da Biologia do Conhecer. Ao ser informado pelo pesquisador Jacqueline Camargo Nogueira Contreiras sobre a minha participação nesta investigação, ficaram claros para mim quais serão os propósitos de estudo, os procedimentos a serem realizados $\mathrm{e}$ as garantias de confidencialidade. Entendi também que as minhas produções entendidas como, textos, entrevistas, declarações, questionários tanto gravadas ou escritas serão analisadas e publicadas (guardada a minha não identificação por nome próprio). Sabendo que poderei retirar o meu consentimento a qualquer momento, durante ou depois do estudo. Sendo assim, declaro que concordo em participar voluntariamente desta pesquisa.

Nome do voluntário

$\mathrm{RG} \mathrm{n}^{\circ}$

Assinatura

Data 


\section{ANEXOS}

\section{ANEXO 1- Resultados da análise de variância (ANOVA)}

Tabela 10: Resultados da ANOVA para as afirmações 1 a 5.

\begin{tabular}{|l|l|l|l|l|l|l|l|l|l|l|}
\hline & \multicolumn{2}{|c|}{ AF1 } & \multicolumn{2}{c|}{ AF2 } & \multicolumn{2}{c|}{ AF3 } & \multicolumn{2}{c|}{ AF4 } & \multicolumn{2}{c|}{ AF5 } \\
\hline & F & p & F & p & F & p & F & p & F & p \\
\hline Sexo & 2,002 & 0,166 & 1,411 & 0,243 & 0,121 & 0,730 & 0,012 & 0,912 & 0,002 & 0,961 \\
\hline Faixa Etária & 1,830 & 0,146 & 0,489 & 0,744 & 1,070 & 0,387 & 0,200 & 0,937 & 0,115 & 0,976 \\
\hline Disciplina & 1,008 & 0,402 & 0,027 & 0,994 & 1,093 & 0,366 & 0,283 & 0,838 & 1,772 & 0,172 \\
\hline $\begin{array}{l}\text { Tempo de } \\
\text { Serviço }\end{array}$ & 0,217 & 0,927 & 0,444 & 0,776 & 0,130 & 0,970 & 0,188 & 0,943 & 0,326 & 0,859 \\
\hline
\end{tabular}

Tabela 11: Resultados da ANOVA para as afirmações 6 a10.

\begin{tabular}{|l|l|l|l|l|l|l|l|l|l|l|}
\hline & \multicolumn{2}{|c|}{ AF6 } & \multicolumn{2}{c|}{ AF7 } & \multicolumn{2}{c|}{ AF8 } & \multicolumn{2}{c|}{ AF9 } & \multicolumn{2}{c|}{ AF10 } \\
\hline & F & $\mathbf{p}$ & F & p & F & p & F & p & F & p \\
\hline Sexo & 0,673 & 0,418 & 5,599 & 0,024 & 0,572 & 0,455 & 0,069 & 0,795 & 0,033 & 0,857 \\
\hline Faixa Etária & 1,688 & 0,176 & 0,602 & 0,664 & 2,103 & 0,103 & 1,233 & 0,316 & 2,778 & 0,043 \\
\hline Disciplina & 0,553 & 0,649 & 0,379 & 0,769 & 0,272 & 0,845 & 0,300 & 0,825 & 0,636 & 0,597 \\
\hline $\begin{array}{l}\text { Tempo de } \\
\text { Serviço }\end{array}$ & 0,956 & 0,444 & 0,595 & 0,669 & 0,988 & 0,428 & 3,638 & 0,015 & 1,999 & 0,118 \\
\hline
\end{tabular}

Tabela 12: Resultados da ANOVA para as afirmações 11 a 15.

\begin{tabular}{|l|l|l|l|l|l|l|l|l|l|l|}
\hline & \multicolumn{2}{|c|}{ AF11 } & \multicolumn{2}{c|}{ AF12 } & \multicolumn{2}{c|}{ AF13 } & \multicolumn{2}{c|}{ AF14 } & \multicolumn{2}{c|}{ AF15 } \\
\hline & F & p & F & p & F & p & F & p & F & p \\
\hline Sexo & 0,965 & 0,333 & 0,137 & 0,714 & 9,325 & 0,004 & 0,322 & 0,575 & 2,095 & 0,157 \\
\hline Faixa Etária & 0,244 & 0,911 & 0,382 & 0,820 & 1,527 & 0,217 & 1,048 & 0,397 & 0,853 & 0,502 \\
\hline Disciplina & 0,139 & 0,936 & 1,093 & 0,366 & 3,182 & 0,037 & 2,595 & 0,069 & 0,692 & 0,564 \\
\hline $\begin{array}{l}\text { Tempo de } \\
\text { Serviço }\end{array}$ & 0,615 & 0,655 & 0,249 & 0,908 & 2,419 & 0,068 & 0,561 & 0,693 & 1,121 & 0,363 \\
\hline
\end{tabular}


Tabela 13: Teste de Tukey das notas da AF2

\begin{tabular}{|l|l|l|l|}
\hline \multicolumn{1}{|c|}{ Fator } & N & NOTA-AF2 & NOTA-AF2 \\
\hline Total & 46 & 6.5 & 2.00 \\
\hline Sexo & & & \\
\hline Feminino & 28 & 6.2 & 2.10 \\
\hline Masculino & 18 & 7.0 & 1.78 \\
\hline Faixa etária & & & \\
\hline $18-24 a$ & 5 & 6.6 & 2.07 \\
\hline $25-34 a$ & 13 & 6.7 & 1.75 \\
\hline $35-44 a$ & 13 & 7.1 & 2.02 \\
\hline $45-54 a$ & 9 & 5.6 & 2.65 \\
\hline$+55^{a}$ & 6 & 6.5 & 1.22 \\
\hline Disciplina & & & \\
\hline Química & 6 & 6.5 & 1.76 \\
\hline Física & 9 & 7.0 & 1.80 \\
\hline Biologia & 24 & 6.4 & 2.16 \\
\hline Matemática & 7 & 6.6 & 2.15 \\
\hline Tempo de serviço & & & \\
\hline$<5 a$ & 13 & 6.8 & 1.91 \\
\hline $5-10 a$ & 11 & 6.4 & 2.11 \\
\hline $11-15 a$ & 5 & 7.6 & 1.52 \\
\hline $16-20 a$ & 6 & 6.7 & 0.82 \\
\hline$+21 a$ & 11 & 5.8 & 2.56 \\
\hline
\end{tabular}

Tabela 14: Teste de Tukey das notas da AF3

\begin{tabular}{|l|l|l|l|}
\hline \multicolumn{1}{|c|}{ Fator } & N & NOTA-AF3 & NOTA-AF3 \\
\hline Total & 46 & 6.0 & 2.27 \\
\hline Sexo & & & \\
\hline Feminino & 28 & 6.1 & 2.25 \\
\hline Masculino & 18 & 5.7 & 2.35 \\
\hline Faixa etária & & & \\
\hline $18-24 a$ & 5 & 3.6 & 3.21 \\
\hline $25-34 a$ & 13 & 6.5 & 1.71 \\
\hline $35-44 a$ & 13 & 5.8 & 2.58 \\
\hline $45-54 a$ & 9 & 6.7 & 1.12 \\
\hline$+55 a$ & 6 & 6.0 & 2.45 \\
\hline Disciplina & & & \\
\hline Química & 6 & 6.8 & 0.75 \\
\hline Física & 9 & 5.3 & 3.04 \\
\hline Biologia & 24 & 6.5 & 2.08 \\
\hline Matemática & 7 & 4.3 & 1.89 \\
\hline Tempo de serviço & & & \\
\hline$<5 a$ & 13 & 5.6 & 2.69 \\
\hline $5-10 a$ & 11 & 6.1 & 2.17 \\
\hline $11-15 a$ & 5 & 5.6 & 3.21 \\
\hline $16-20 a$ & 6 & 6.0 & 1.67 \\
\hline$+21 a$ & 11 & 6.4 & 1.96 \\
\hline
\end{tabular}


Tabela 15: Teste de Tukey das notas da AF4

\begin{tabular}{|l|l|l|l|}
\hline \multicolumn{1}{|c|}{ Fator } & \multicolumn{1}{|c|}{ N } & $\begin{array}{c}\text { NOTA- } \\
\text { AF4 }\end{array}$ & $\begin{array}{c}\text { NOTA- } \\
\text { AF4 }\end{array}$ \\
\hline Total & 46 & 6.3 & 2.08 \\
\hline Sexo & & & \\
\hline Feminino & 28 & 6.4 & 2.13 \\
\hline Masculino & 18 & 6.1 & 2.05 \\
\hline Faixa etária & & & \\
\hline $18-24 a$ & 5 & 6.6 & 1.52 \\
\hline $25-34 a$ & 13 & 6.6 & 2.18 \\
\hline $35-44 a$ & 13 & 6.3 & 2.36 \\
\hline $45-54 a$ & 9 & 5.3 & 2.40 \\
\hline$+55 a$ & 6 & 6.5 & 1.05 \\
\hline Disciplina & & & \\
\hline Química & 6 & 5.7 & 2.16 \\
\hline Física & 9 & 6.6 & 2.51 \\
\hline Biologia & 24 & 6.5 & 2.13 \\
\hline Matemática & 7 & 5.7 & 1.38 \\
\hline Tempo de serviço & & & \\
\hline$<5 a$ & 13 & 6.6 & 1.94 \\
\hline $5-10 a$ & 11 & 6.7 & 1.90 \\
\hline $11-15 a$ & 5 & 5.8 & 3.42 \\
\hline $16-20 a$ & 6 & 5.5 & 2.17 \\
\hline$+21 a$ & 11 & 6.0 & 1.84 \\
\hline & & &
\end{tabular}

Tabela 16: Teste de Tukey das notas da AF5

\begin{tabular}{|l|l|l|l|}
\hline \multicolumn{1}{|c|}{ Fator } & N & NOTA-AF5 & NOTA-AF5 \\
\hline Total & 46 & 6.1 & 1.91 \\
\hline Sexo & & & \\
\hline Feminino & 28 & 6.1 & 2.02 \\
\hline Masculino & 18 & 6.1 & 1.78 \\
\hline Faixa etária & & & \\
\hline $18-24 a$ & 5 & 6.2 & 1.10 \\
\hline $25-34 a$ & 13 & 6.5 & 2.11 \\
\hline $35-44 a$ & 13 & 6.2 & 1.72 \\
\hline $45-54 a$ & 9 & 5.3 & 2.60 \\
\hline$+55 a$ & 6 & 6.3 & 1.37 \\
\hline Disciplina & & & \\
\hline Química & 6 & 5.0 & 2.68 \\
\hline Física & 9 & 7.2 & 1.20 \\
\hline Biologia & 24 & 6.3 & 1.81 \\
\hline Matemática & 7 & 5.0 & 1.53 \\
\hline Tempo de serviço & & & \\
\hline$<5 a$ & 13 & 6.5 & 1.51 \\
\hline $5-10 a$ & 11 & 6.1 & 1.70 \\
\hline $11-15 a$ & 5 & 6.8 & 1.92 \\
\hline $16-20 a$ & 6 & 4.8 & 2.79 \\
\hline$+21 a$ & 11 & 6.1 & 2.02 \\
\hline
\end{tabular}


Tabela 16: Teste de Tukey das notas da AF6

\begin{tabular}{|l|l|l|l|}
\hline \multicolumn{1}{|c|}{ Fator } & N & NOTA-AF6 & NOTA-AF6 \\
\hline Total & 46 & 6.7 & 1.66 \\
\hline Sexo & & & \\
\hline Feminino & 28 & 6.7 & 1.80 \\
\hline Masculino & 18 & 6.6 & 1.46 \\
\hline Faixa etária & & & \\
\hline $18-24 a$ & 5 & 5.8 & 1.92 \\
\hline $25-34 a$ & 13 & 6.9 & 1.44 \\
\hline $35-44 a$ & 13 & 6.8 & 1.68 \\
\hline $45-54 a$ & 9 & 7.0 & 1.41 \\
\hline$+55 a$ & 6 & 5.8 & 2.23 \\
\hline Disciplina & & & \\
\hline Química & 6 & 7.2 & 1.47 \\
\hline Física & 9 & 6.4 & 1.94 \\
\hline Biologia & 24 & 6.5 & 1.72 \\
\hline Matemática & 7 & 6.9 & 1.46 \\
\hline Tempo de serviço & & & \\
\hline$<5 a$ & 13 & 6.8 & 1.69 \\
\hline $5-10 a$ & 11 & 6.9 & 1.22 \\
\hline $11-15 a$ & 5 & 6.8 & 2.28 \\
\hline $16-20 a$ & 6 & 6.3 & 1.86 \\
\hline$+21 a$ & 11 & 6.4 & 1.86 \\
\hline
\end{tabular}

Tabela 17: Teste de Tukey das notas da AF7

\begin{tabular}{|l|l|l|l|}
\hline \multicolumn{1}{|c|}{ Fator } & N & NOTA-AF7 & NOTA-AF7 \\
\hline Total & 46 & 8.0 & 0.92 \\
\hline Sexo & & & \\
\hline Feminino & 28 & $8.3^{\mathrm{a}}$ & 0.72 \\
\hline Masculino & 18 & $7.6 \mathrm{~b}$ & 1.04 \\
\hline Faixa etária & & & \\
\hline $18-24 a$ & 5 & 7.4 & 1.52 \\
\hline $25-34 a$ & 13 & 8.4 & 0.77 \\
\hline $35-44 a$ & 13 & 8.2 & 0.80 \\
\hline $45-54 a$ & 9 & 7.8 & 0.83 \\
\hline$+55 a$ & 6 & 8.0 & 0.89 \\
\hline Disciplina & & & \\
\hline Química & 6 & 7.7 & 0.52 \\
\hline Física & 9 & 7.9 & 0.93 \\
\hline Biologia & 24 & 8.2 & 0.98 \\
\hline Matemática & 7 & 8.0 & 1.00 \\
\hline Tempo de serviço & & & \\
\hline$<5 a$ & 13 & 7.8 & 1.14 \\
\hline $5-10 a$ & 11 & 8.5 & 0.69 \\
\hline $11-15 a$ & 5 & 8.0 & 1.00 \\
\hline $16-20 a$ & 6 & 7.8 & 0.98 \\
\hline$+21 a$ & 11 & 8.0 & 0.77 \\
\hline
\end{tabular}


Tabela 18: Teste de Tukey das notas da AF8

\begin{tabular}{|l|l|l|l|}
\hline \multicolumn{1}{|c|}{ Fator } & N & NOTA-AF8 & NOTA-AF8 \\
\hline Total & 46 & 8.4 & 0.65 \\
\hline Sexo & & & \\
\hline Feminino & 28 & 8.5 & 0.69 \\
\hline Masculino & 18 & 8.3 & 0.57 \\
\hline Faixa etária & & & \\
\hline $18-24 a$ & 5 & 8.0 & 0.71 \\
\hline $25-34 a$ & 13 & 8.6 & 0.65 \\
\hline $35-44 a$ & 13 & 8.5 & 0.52 \\
\hline $45-54 a$ & 9 & 8.1 & 0.78 \\
\hline$+55 a$ & 6 & 8.7 & 0.52 \\
\hline Disciplina & & & \\
\hline Química & 6 & 8.5 & 0.84 \\
\hline Física & 9 & 8.3 & 0.71 \\
\hline Biologia & 24 & 8.5 & 0.59 \\
\hline Matemática & 7 & 8.3 & 0.76 \\
\hline Tempo de serviço & & & \\
\hline$<5 a$ & 13 & 8.4 & 0.65 \\
\hline $5-10 a$ & 11 & 8.5 & 0.69 \\
\hline $11-15 a$ & 5 & 8.6 & 0.55 \\
\hline $16-20 a$ & 6 & 8.2 & 0.98 \\
\hline$+21 a$ & 11 & 8.5 & 0.52 \\
\hline & &
\end{tabular}

Tabela 19: Teste de Tukey das notas da AF9

\begin{tabular}{|c|c|c|c|}
\hline Fator & $\mathbf{N}$ & NOTA-AF9 & NOTA-AF9 \\
\hline Total & 46 & 8.3 & 0.74 \\
\hline \multicolumn{4}{|l|}{ Sexo } \\
\hline Feminino & 28 & $8.4^{a} \pm 0.68$ & 0.68 \\
\hline Masculino & 18 & $8.3^{a} \pm 0.84$ & 0.84 \\
\hline \multicolumn{4}{|l|}{ Faixa etária } \\
\hline $18-24 a$ & 5 & $8.2^{a} \pm 0.45$ & 0.45 \\
\hline $25-34 a$ & 13 & $8.3^{\mathrm{a}} \pm 0.85$ & 0.85 \\
\hline $35-44 a$ & 13 & $8.3^{a} \pm 0.85$ & 0.85 \\
\hline $45-54 a$ & 9 & $8.4^{a} \pm 0.73$ & 0.73 \\
\hline$+55 a$ & 6 & $8.5^{\mathrm{a}} \pm 0.55$ & 0.55 \\
\hline \multicolumn{4}{|l|}{ Disciplina } \\
\hline Química & 6 & $8.2^{\underline{a}} \pm 0.98$ & 0.98 \\
\hline Física & 9 & $8.4^{a} \pm 0.73$ & 0.73 \\
\hline Biologia & 24 & $8.3^{\mathrm{a}} \pm 0.70$ & 0.70 \\
\hline Matemática & 7 & $8.4^{\mathrm{a}} \pm 0.79$ & 0.79 \\
\hline \multicolumn{4}{|l|}{ Tempo de serviço } \\
\hline$<5 a$ & 13 & $7.8 b \pm 0.69$ & 0.69 \\
\hline $5-10 a$ & 11 & $8.5^{\underline{a}} \pm 0.69$ & 0.69 \\
\hline $11-15 a$ & 5 & $8.6^{\mathrm{a}} \pm 0.89$ & 0.89 \\
\hline $16-20 a$ & 6 & $8.3 a b \pm 0.82$ & 0.82 \\
\hline$+21 a$ & 11 & $8.6^{\mathrm{a}} \pm 0.50$ & 0.50 \\
\hline
\end{tabular}


Tabela 20: Teste de Tukey das notas da AF10

\begin{tabular}{|l|l|l|l|}
\hline Total & $\mathbf{N}$ & NOTA-AF10 & NOTA-AF10 \\
\hline Sexo & 46 & 5.0 & 2.50 \\
\hline Feminino & & & \\
\hline Masculino & 28 & $5.0 \pm 2.71$ & 2.71 \\
\hline Faixa etária & 18 & $5.1 \pm 2.19$ & 2.19 \\
\hline $18-24 a$ & & & \\
\hline $25-34 a$ & 5 & $4.6 \mathrm{~b} \pm 1.52$ & 1.52 \\
\hline $35-44 a$ & 13 & $4.7 \mathrm{~b} \pm 2.53$ & 2.53 \\
\hline $45-54 a$ & 13 & $6.0 \mathrm{a} \pm 2.58$ & 2.58 \\
\hline$+55 a$ & 9 & $3.4 \mathrm{~b} \pm 2.60$ & 2.60 \\
\hline Disciplina & 6 & $6.3^{a} \pm 1.63$ & 1.63 \\
\hline Química & & & \\
\hline Física & 6 & $4.8 \pm 2.93$ & 2.93 \\
\hline Biologia & 9 & $5.4 \pm 2.35$ & 2.35 \\
\hline Matemática & 24 & $4.9 \pm 2.82$ & 2.82 \\
\hline Tempo de serviço & 7 & $5.1 \pm 1.21$ & 1.21 \\
\hline$<5 a$ & & & \\
\hline $5-10 a$ & 13 & $5.1 \pm 2.22$ & 2.22 \\
\hline $11-15 a$ & 11 & $4.5 \pm 2.58$ & 2.58 \\
\hline $16-20 a$ & 5 & $7.0 \pm 2.35$ & 2.35 \\
\hline$+21 a$ & 6 & $5.7 \pm 2.25$ & 2.25 \\
\hline Total & 11 & $4.3 \pm 2.76$ & 2.76 \\
\hline
\end{tabular}

Tabela 21: Teste de Tukey das notas da AF11

\begin{tabular}{|l|l|l|l|}
\hline \multicolumn{1}{|c|}{ Fator } & N & NOTA-AF11 & NOTA-AF11 \\
\hline Total & 46 & 7.3 & 1.91 \\
\hline Sexo & & & \\
\hline Feminino & 28 & $7.5 \pm 2.08$ & 2.08 \\
\hline Masculino & 18 & $7.0 \pm 1.61$ & 1.61 \\
\hline Faixa etária & & & \\
\hline $18-24 a$ & 5 & $7.8 \pm 1.64$ & 1.64 \\
\hline $25-34 a$ & 13 & $7.1 \pm 2.29$ & 2.29 \\
\hline $35-44 a$ & 13 & $7.4 \pm 1.80$ & 1.80 \\
\hline $45-54 a$ & 9 & $7.0 \pm 2.24$ & 2.24 \\
\hline$+55 a$ & 6 & $7.5 \pm 1.22$ & 1.22 \\
\hline Disciplina & & & \\
\hline Química & 6 & $7.2 \pm 2.23$ & 2.23 \\
\hline Física & 9 & $7.8 \pm 1.20$ & 1.20 \\
\hline Biologia & 24 & $7.2 \pm 2.25$ & 2.25 \\
\hline Matemática & 7 & $7.0 \pm 1.15$ & 1.15 \\
\hline Tempo de serviço & & & \\
\hline$<5 a$ & 13 & $7.3 \pm 2.18$ & 2.18 \\
\hline $5-10 a$ & 11 & $6.8 \pm 1.94$ & 1.94 \\
\hline $11-15 a$ & 5 & $8.4 \pm 1.34$ & 1.34 \\
\hline $16-20 a$ & 6 & $7.3 \pm 1.37$ & 1.37 \\
\hline$+21 a$ & 11 & $7.2 \pm 2.09$ & 2.09 \\
\hline & & & \\
\hline
\end{tabular}


Tabela 22: Teste de Tukey das notas da AF12

\begin{tabular}{|l|l|l|l|}
\hline \multicolumn{1}{|c|}{ Fator } & N & NOTA-AF12 & NOTA-AF12 \\
\hline Total & 46 & $5.7 \pm$ & 2.57 \\
\hline Sexo & & & \\
\hline Feminino & 28 & $5.7 \pm 2.64$ & 2.64 \\
\hline Masculino & 18 & $5.8 \pm 2.53$ & 2.53 \\
\hline Faixa etária & & & \\
\hline $18-24 a$ & 5 & $5.4 \pm 2.88$ & 2.88 \\
\hline $25-34 a$ & 13 & $6.5 \pm 2.18$ & 2.18 \\
\hline $35-44 a$ & 13 & $5.7 \pm 2.78$ & 2.78 \\
\hline $45-54 a$ & 9 & $5.0 \pm 3.43$ & 3.43 \\
\hline$+55 a$ & 6 & $5.7 \pm 1.21$ & 1.21 \\
\hline Disciplina & & & \\
\hline Química & 6 & $6.7 \pm 2.73$ & 2.73 \\
\hline Física & 9 & $4.8 \pm 2.95$ & 2.95 \\
\hline Biologia & 24 & $6.0 \pm 2.54$ & 2.54 \\
\hline Matemática & 7 & $5.4 \pm 2.07$ & 2.07 \\
\hline Tempo de serviço & & & \\
\hline$<5 a$ & 13 & $5.7 \pm 2.36$ & 2.36 \\
\hline $5-10 a$ & 11 & $6.1 \pm 2.34$ & 2.34 \\
\hline $11-15 a$ & 5 & $6.6 \pm 3.58$ & 3.58 \\
\hline $16-20 a$ & 6 & $5.5 \pm 2.51$ & 2.51 \\
\hline$+21 a$ & 11 & $5.2 \pm 2.89$ & 2.89 \\
\hline & & & \\
\hline
\end{tabular}

Tabela 23: Teste de Tukey das notas da AF13

\begin{tabular}{|l|l|l|l|}
\hline \multicolumn{1}{|c|}{ Fator } & N & NOTA-AF13 & NOTA-AF13 \\
\hline Total & 46 & 8.2 & 0.85 \\
\hline Sexo & & & \\
\hline Feminino & 28 & $8.5^{\mathrm{a}} \pm 0.74$ & 0.74 \\
\hline Masculino & 18 & $7.8 \mathrm{~b} \pm 0.81$ & 0.81 \\
\hline Faixa etária & & & \\
\hline $18-24 a$ & 5 & $8.0 \pm 0.00$ & 0.00 \\
\hline $25-34 a$ & 13 & $8.2 \pm 1.07$ & 1.07 \\
\hline $35-44 a$ & 13 & $8.4 \pm 0.65$ & 0.65 \\
\hline $45-54 a$ & 9 & $8.0 \pm 1.12$ & 1.12 \\
\hline$+55 a$ & 6 & $8.7 \pm 0.52$ & 0.52 \\
\hline Disciplina & & & \\
\hline Química & 6 & $8.0 \mathrm{ab} \pm 1.26$ & 1.26 \\
\hline Física & 9 & $8.3^{\mathrm{a}} \pm 0.50$ & 0.50 \\
\hline Biologia & 24 & $8.5^{\mathrm{a}} \pm 0.72$ & 0.72 \\
\hline Matemática & 7 & $7.6 \mathrm{~b} \pm 0.98$ & 0.98 \\
\hline Tempo de serviço & & & \\
\hline$<5 a$ & 13 & $8.3 \pm 0.63$ & 0.63 \\
\hline $5-10 a$ & 11 & $8.5 \pm 0.69$ & 0.69 \\
\hline $11-15 \mathrm{a}$ & 5 & $7.4 \pm 1.14$ & 1.14 \\
\hline $16-20 \mathrm{a}$ & 6 & $7.8 \pm 0.75$ & 0.75 \\
\hline$+21 \mathrm{a}$ & 11 & $8.5 \pm 0.93$ & 0.93 \\
\hline
\end{tabular}


Tabela 24: Teste de Tukey das notas da AF14

\begin{tabular}{|l|l|l|l|}
\hline \multicolumn{1}{|c|}{ Fator } & N & NOTA-AF14 & NOTA-AF14 \\
\hline Total & 46 & 5.1 & 2.93 \\
\hline Sexo & & & \\
\hline Feminino & 28 & $4.9 \pm 2.99$ & 2.99 \\
\hline Masculino & 18 & $5.4 \pm 2.89$ & 2.89 \\
\hline Faixa etária & & & \\
\hline $18-24 a$ & 5 & $3.2 \pm 2.17$ & 2.17 \\
\hline $25-34 a$ & 13 & $4.9 \pm 2.60$ & 2.60 \\
\hline $35-44 a$ & 13 & $6.5 \pm 2.79$ & 2.79 \\
\hline $45-54 a$ & 9 & $4.9 \pm 3.02$ & 3.02 \\
\hline$+55 a$ & 6 & $4.5 \pm 3.89$ & 3.89 \\
\hline Disciplina & & & \\
\hline Química & 6 & $8.0 \pm 0.63$ & 0.63 \\
\hline Física & 9 & $4.2 \pm 3.11$ & 3.11 \\
\hline Biologia & 24 & $4.9 \pm 3.02$ & 3.02 \\
\hline Matemática & 7 & $4.4 \pm 2.44$ & 2.44 \\
\hline Tempo de servico & & & \\
\hline$<5 a$ & 13 & $4.2 \pm 2.65$ & 2.65 \\
\hline $5-10 a$ & 11 & $5.9 \pm 2.74$ & 2.74 \\
\hline $11-15 a$ & 5 & $5.6 \pm 3.21$ & 3.21 \\
\hline $16-20 a$ & 6 & $5.8 \pm 2.86$ & 2.86 \\
\hline$+21 a$ & 11 & $4.7 \pm 3.50$ & 3.50 \\
\hline & & & \\
\hline
\end{tabular}

Tabela 25: Teste de Tukey das notas da AF15

\begin{tabular}{|l|l|l|l|}
\hline \multicolumn{1}{|c|}{ Fator } & N & $\begin{array}{c}\text { NOTA } \\
\text { AF15 }\end{array}$ & NOTA-AF15 \\
\hline Total & 46 & 7.2 & 1.78 \\
\hline Sexo & & & \\
\hline Feminino & 28 & $7.5 \pm 1.86$ & 1.86 \\
\hline Masculino & 18 & $6.9 \pm 1.64$ & 1.64 \\
\hline Faixa etária & & & \\
\hline $18-24 a$ & 5 & $7.8 \pm 1.30$ & 1.30 \\
\hline $25-34 a$ & 13 & $7.4 \pm 0.96$ & 0.96 \\
\hline $35-44 a$ & 13 & $8.2 \pm 0.93$ & 0.93 \\
\hline $45-54 a$ & 9 & $5.7 \pm 2.87$ & 2.87 \\
\hline$+55 a$ & 6 & $6.7 \pm 1.37$ & 1.37 \\
\hline Disciplina & & & \\
\hline Química & 6 & $7.7 \pm 1.37$ & 1.37 \\
\hline Física & 9 & $7.7 \pm 1.22$ & 1.22 \\
\hline Biologia & 24 & $6.9 \pm 2.15$ & 2.15 \\
\hline Matemática & 7 & $7.4 \pm 1.27$ & 1.27 \\
\hline Tempo de servico & & & \\
\hline$<5 a$ & 13 & $7.6 \pm 0.96$ & 0.96 \\
\hline $5-10 a$ & 11 & $8.0 \pm 1.00$ & 1.00 \\
\hline $11-15 a$ & 5 & $7.4 \pm 1.34$ & 1.34 \\
\hline $16-20 a$ & 6 & $7.8 \pm 1.17$ & 1.17 \\
\hline$+21 a$ & 11 & $5.6 \pm 2.62$ & 2.62 \\
\hline & \multicolumn{3}{|l}{} \\
\hline
\end{tabular}


Tabela 26. Resumo estatístico das notas atribuídas pelos entrevistados a cada afirmação.

\begin{tabular}{|c|c|l|l|l|l|l|}
\hline Afirmação & $\mathbf{n}$ & Media & Mediana & Mínimo & Maximo & Desvio Padrão \\
\hline AF1 & 46 & 7.7 & 8.0 & 5.0 & 9.0 & 1.19 \\
\hline AF2 & 46 & 6.5 & 7.0 & 1.0 & 9.0 & 2.00 \\
\hline AF3 & 46 & 6.0 & 6.5 & 1.0 & 9.0 & 2.27 \\
\hline AF4 & 46 & 6.3 & 6.5 & 1.0 & 9.0 & 2.08 \\
\hline AF5 & 46 & 6.1 & 6.0 & 1.0 & 9.0 & 1.91 \\
\hline AF6 & 46 & 6.7 & 7.0 & 2.0 & 9.0 & 1.66 \\
\hline AF7 & 46 & 8.0 & 8.0 & 5.0 & 9.0 & 0.92 \\
\hline AF8 & 46 & 8.4 & 9.0 & 7.0 & 9.0 & 0.65 \\
\hline AF9 & 46 & 8.3 & 8.5 & 7.0 & 9.0 & 0.74 \\
\hline AF10 & 46 & 5.0 & 5.0 & 1.0 & 9.0 & 2.50 \\
\hline AF11 & 46 & 7.3 & 8.0 & 1.0 & 9.0 & 1.91 \\
\hline AF12 & 46 & 5.7 & 6.0 & 1.0 & 9.0 & 2.57 \\
\hline AF13 & 46 & 8.2 & 8.0 & 6.0 & 9.0 & 0.85 \\
\hline AF14 & 46 & 5.1 & 5.0 & 1.0 & 9.0 & 2.93 \\
\hline AF15 & 46 & 7.2 & 8.0 & 1.0 & 9.0 & 1.78 \\
\hline
\end{tabular}

